NBER WORKING PAPER SERIES

\title{
INDUSTRIALIZATION WITHOUT INNOVATION
}

\author{
Paula Bustos \\ Juan Manuel Castro-Vincenzi \\ Joan Monras \\ Jacopo Ponticelli \\ Working Paper 25871 \\ http://www.nber.org/papers/w25871
NATIONAL BUREAU OF ECONOMIC RESEARCH
1050 Massachusetts Avenue
Cambridge, MA 02138
May 2019, Revised March 2022

\begin{abstract}
We received valuable comments from Thibault Fally, Manuel García-Santana, Donald Davis, Gene Grossman, Michael Peters, Diego Puga, Sergio Rebelo, Andres Rodriguez-Clare, Chris Tonetti, Chris Udry, Jose P. Vasquez, and seminar participants at CEMFI, CREI, Lugano, Columbia, Northwestern, BdE, the NBER Economic Consequences of Trade, McGill, Princeton Growth Conference, GEP/CEPR Summer Trade Workshop, and the Workshop on Structural Transformation and Macroeconomic Dynamics. This project has received funding from the European Research Council (ERC) under the European Union's Horizon 2020 research and innovation program (grant agreement no. 716388). We are also grateful to acknowledge financial support from the UK Department for International Development (DFID) and the Centre for Economic Policy Research (CEPR) (PEDL Scale-Up ERG no. 3787). Monras acknowledges financial support from the Spanish Agencia Estatal de Investigación (AEI), through the Severo Ochoa Programme for Centres of Excellence in R\&D (Barcelona School of Economics CEX2019-000915-S). Mark He and Erick Molina provided excellent research assistance. An earlier version of this paper circulated under the title "Structural Transformation, Industrial Specialization, and Endogenous Growth". The views expressed herein are those of the authors and do not necessarily reflect the views of the National Bureau of Economic Research.
\end{abstract}

NBER working papers are circulated for discussion and comment purposes. They have not been peer-reviewed or been subject to the review by the NBER Board of Directors that accompanies official NBER publications.

(C) 2019 by Paula Bustos, Juan Manuel Castro-Vincenzi, Joan Monras, and Jacopo Ponticelli. All rights reserved. Short sections of text, not to exceed two paragraphs, may be quoted without explicit permission provided that full credit, including $(\subset)$ notice, is given to the source. 
Industrialization without Innovation

Paula Bustos, Juan Manuel Castro-Vincenzi, Joan Monras, and Jacopo Ponticelli

NBER Working Paper No. 25871

May 2019, Revised March 2022

JEL No. F1,F16,F43,O1,O13,O4

\begin{abstract}
The introduction of labor-saving technologies in agriculture can foster structural transformation by releasing workers who find occupation in other sectors. The traditional view is that the reallocation of labor towards manufacturing generates innovation and productivity growth. We conduct an empirical investigation of this structural transformation process in the context of a large and exogenous increase in agricultural productivity in Brazil. We find that workers leaving agriculture were mostly unskilled. Thus, they found employment in the least skill-intensive manufacturing industries. Next, we investigate the effect of this change in comparative advantage within the manufacturing sector on innovation. We use social security data to develop a new measure of the labor input in innovation that is representative at any level of spatial aggregation. We find that regions with faster agricultural productivity growth experienced a reallocation of unskilled workers away from agriculture into the least R\&D-intensive manufacturing industries. The expansion of low-R\&D industries attracted workers away from innovative occupations in high-R\&D industries, slowing down local aggregate manufacturing productivity growth.

\author{
Paula Bustos \\ Centro de Estudios Monetarios y Financieros \\ Casado del Alisal 5, 28014 Madrid \\ Spain \\ paula.bustos@cemfi.es \\ Juan Manuel Castro-Vincenzi \\ Department of Economics \\ Princeton University \\ Julis Romo Rabinowitz Building \\ 20 Washington Rd \\ Princeton, NJ 08544 \\ castro.vincenzi@princeton.edu
}

\author{
Joan Monras \\ Universitat Pompeu Fabra \\ Ramon Trias Fargas, 25 \\ 08005 Barcelona \\ Spain \\ jmonras@princeton.edu \\ Jacopo Ponticelli \\ Kellogg School of Management \\ Northwestern University \\ 2211 Campus Drive \\ Evanston, IL 60208 \\ and NBER \\ jacopo.ponticelli@kellogg.northwestern.edu
}




\section{Introduction}

Early development economists argued that the reallocation of workers from agriculture to manufacturing was fundamental to sustain long run growth (Lewis 1954, Kuznets 1973). This structural transformation process can lead to higher output because labor productivity is lower in agriculture than in the rest of the economy (Caselli 2005, Restuccia, Yang, and Zhu 2008, Lagakos and Waugh 2013). In addition, the manufacturing sector is characterized by economies of scale and knowledge spillovers. As a result, industrialization can lead to higher long run growth (Krugman 1987, Lucas 1988, Matsuyama 1992a). In this paper, we qualify these views by noting that manufacturing productivity growth depends not only on the size of the industrial sector but also on its composition (Grossman and Helpman 1991). Thus, if workers leaving the agricultural sector are mostly unskilled, the structural transformation process can reinforce comparative advantage in non-innovating industries, reducing long run growth.

We provide direct evidence on this structural transformation process in the context of a large increase in agricultural productivity due to the adoption of genetically engineered (GE) soy in Brazil. To identify the causal effects of this new technology on industrial development, we exploit its heterogeneous effects on potential yields across regions with different weather and soil characteristics. We think of these regions as small open economies that were differently exposed to the new technology, which permits to estimate the effects of local agricultural technical change on local labor reallocation, industrial specialization and productivity growth. ${ }^{1}$ To trace the effects of technical change in soy from the agricultural to the manufacturing sector, we rely on detailed individual information from the Brazilian Population Census and social security data (RAIS) which allows to follow workers across sectors at fine levels of spatial aggregation. In turn, to focus on the manufacturing sector we use firm-level data from the Brazilian Annual Industrial Survey (PIA) and the Technological Innovation Survey (PINTEC).

We start by studying the effects of the new agricultural technology on labor allocation across sectors. We build on earlier work showing that GE soy technology is strongly labor-saving. Thus, its adoption increased the comparative advantage in agriculture but released agricultural workers who found employment in the local industrial sector (Bustos, Caprettini, and Ponticelli, 2016). In the current study, we take a step further and analyze the skill composition of workers leaving agriculture. We trace the flow of workers with different education levels across sectors using detailed individual information from the decadal Brazilian Population Census. We find that the new agricultural technology led to a reallocation of mostly unskilled workers away from agriculture towards manufacturing with little reallocation towards services. Our estimates indicate that microregions with a

\footnotetext{
${ }^{1}$ Our geographical units of observation are Brazilian microregions, which attempt to approximate local labor markets. The Brazilian Institute of Geography and Statistics (IBGE) defines these microregions by combining economically integrated municipalities with similar production and geographic characteristics.
} 
one standard deviation higher increase in potential soy yields experienced a 2.4 percentage points larger decrease in the share of unskilled workers employed in agriculture, and a corresponding 2.1 percentage points larger increase in the share of unskilled workers employed in manufacturing. We confirm these findings using yearly information on formal workers from social security data, which shows that the timing of this labor reallocation process corresponds to the timing of adoption of GE seeds.

Next, we study the consequences of this reallocation of unskilled labor from agriculture to manufacturing for industrial specialization. From the point of view of the manufacturing sector, the reallocation of former agricultural workers amounts to an increase in the relative supply of unskilled labor. According to the classic Heckscher-Ohlin trade model, this increase in the relative supply of unskilled labor generates a comparative advantage in unskilled-labor intensive industries, which should expand by absorbing the inflow of unskilled workers and also attract other complementary factors such as capital (Rybczynski, 1955). Indeed, we find that this inflow of unskilled workers was completely absorbed by an expansion of the least skill-intensive manufacturing industries. As expected, the labor inflow was followed by an increase in capital investment. Finally, we document that the expanding industries are the least innovation-intensive as measured by expenditure in research and development $(\mathrm{R} \& \mathrm{D})$ as a share of sales. The theoretical literature discussed above proposes several mechanisms through which changes in the size and composition of the industrial sector can shape manufacturing productivity growth, which we explore next.

We trace the effects of agricultural technical change on manufacturing productivity using data from the yearly manufacturing survey (PIA). We find that microregions facing faster agricultural technical change experienced a slowdown in manufacturing productivity growth. Our estimates imply that microregions with a one standard deviation larger increase in potential soy yields experienced a 7 percent increase in the size of the manufacturing sector and a corresponding 1.5 percent lower yearly growth rate of manufacturing productivity, a result that challenges the traditional view in the literature.

The inflow of low-skill agricultural workers can reduce manufacturing productivity growth through two channels. First, a reallocation of economic activity towards the industry with lower skill and innovation intensity can decrease manufacturing productivity due to a composition effect. Second, an increase in the relative size of the low-skill industry can reduce incentives to innovate within the high-skill industry, as predicted by models of directed technical change based on market size effects à la Romer (1990) such as Acemoglu (2002). We attempt to quantify each of these mechanisms. For this purpose, we split the manufacturing sector by the median level of $\mathrm{R} \& \mathrm{D}$, into $H$ and $L$ industries. Then, we decompose the manufacturing productivity slowdown into between- and within-industry components. We obtain that the between effect, which reflects the impact of factor reallocation towards low productivity industries, can explain at most 8 percent of the 
overall productivity decline. The remainder is explained by a reduction of productivity growth within industries, which is of a similar magnitude in both $H$ and $L$ industries. ${ }^{2}$ This evidence suggests that the main driver of the productivity slowdown could be lower innovation within industries, which we investigate as follows.

To study the effects of agricultural technical change on industrial innovation, our identification strategy requires a measure of $R \& D$ expenditures at fine levels of spatial aggregation. Standard innovation surveys such as PINTEC do not allow us to implement this strategy, because they are based on a sample of firms which is not representative of small geographical units (microregions). ${ }^{3}$ To overcome this problem, we propose a new measure of innovation that is representative at any level of geographical aggregation because it can be constructed using social security data, which covers the universe of formal firms. In particular, we measure the labor input in the production of innovations using textual analysis of the task descriptions of more than 2,500 occupations in RAIS. Tasks generating innovations include, for example, developing or adapting new products and processes, creating prototypes, or optimizing methods of production.

We use this measure to document that in regions more exposed to agricultural technical change, the inflow of low-skill agricultural workers into $L$ manufacturing industries was followed by a reallocation of innovation workers away from $H$ industries. In particular, microregions with a one standard deviation larger increase in potential soy yields experienced a 20 percent larger decline in innovation expenditures in $H$ industries, measured as the wage bill of workers in innovative occupations. We show that this decline is explained by both lower retention and lower entry of workers in innovative occupations within $H$ industries. Next, we trace the employment path of innovation workers initially employed in $H$ industries, and find that a quarter of lower retention is explained by reallocation to $L$ industries. Finally, we show that a third of those former innovative workers end up in non-innovative occupations within $L$ industries. Indeed, we do not find a significant increase in innovation expenditures within $L$ industries. These results can explain the decline in manufacturing productivity growth that accompanied the industrialization process in regions subject to faster agricultural technical change. In particular, the reallocation of workers from innovative to non-innovative occupations can reduce local knowledge production and explain the reduction in local manufacturing productivity growth. In the case of the $H$ industry, lower productivity growth can be directly explained by a sharp decline in its innovation expenses. In contrast, the observed reduction in pro-

\footnotetext{
${ }^{2}$ We use three different measures of manufacturing productivity: value added per worker, valued added per wage bill, and a measure of $T F P$. The measure of $T F P$ takes into account changes in the capital stock and educational level of the workforce. In turn, the value added per wage bill measure takes into account both observed and unobserved dimensions of human capital as reflected in wages.

${ }^{3}$ Alternative measures of innovation such as patents might be geographically representative but are not representative of the type of innovations which are most frequent in developing countries. According to PINTEC, only $20 \%$ of firms which introduced innovations in the period 1997-2008 filed a patent application.
} 
ductivity growth within the $L$ industry is not explained by changes in its own innovation expenditures. This finding suggests that innovations generated in the high-R\&D industry generate knowledge spillovers to other industries.

Overall, our empirical findings indicate that unskilled-labor-saving technical change in agriculture can lead to a reallocation of workers toward unskilled-labor-intensive manufacturing industries. In turn, this reallocation leads to an expansion of the industrial sectors with the lowest R\&D intensity in the economy, thereby decreasing innovation. As resources are reallocated toward low-R\&D industries, local knowledge production slows down, leading to lower overall manufacturing productivity growth. We interpret this result as a cautionary tale on the effects of structural change on productivity growth. The adoption of new technologies in agriculture may result in static productivity gains in the agricultural sector but dynamic losses in manufacturing productivity.

Our findings also suggest that different forces driving structural transformation can lead to different types of industrial development. In most countries, the process of labor reallocation from agriculture to manufacturing can be ascribed to one of two forces: "push" forces, such as new agricultural technologies that push workers out of agriculture, or "pull" forces, such as industrial productivity growth, that pull workers into manufacturing. We show that when labor reallocation from agriculture to manufacturing is driven by "push" forces, it can generate an expansion of industries with the lowest potential contribution to aggregate productivity. In this sense, our results are informative for low- to middle-income countries where a large share of the labor force is employed in agriculture, and who import new agricultural technologies from more developed countries.

\section{Related Literature}

There is a long tradition in economics of studying the links between agricultural productivity and industrial development. Nurkse (1953), Schultz (1953), and Rostow (1960) argued that agricultural productivity growth was an essential precondition for the industrial revolution. Classical models of structural transformation formalized their ideas by proposing two main mechanisms through which agricultural productivity can speed up industrial growth in closed economies. First, agricultural productivity growth increases income, which can increase the relative demand for manufacturing goods, driving labor away from agriculture and into manufacturing (see Murphy, Shleifer, and Vishny 1989, Kongsamut, Rebelo, and Xie 2001, Gollin, Parente, and Rogerson 2002, Boppart 2014). Second, if productivity growth in agriculture is faster than in manufacturing and these goods are complements in consumption, the relative demand for agricultural goods does not grow as fast as productivity, and labor reallocates toward manufacturing (Baumol 1967, Ngai and Pissarides 2007). ${ }^{4}$ Note that these two mechanisms are only operative

\footnotetext{
${ }^{4}$ See also: Caselli and Coleman 2001, Acemoglu and Guerrieri 2008, Buera, Kaboski, Rogerson, and Vizcaino 2021.
} 
in closed economies, while in open economies high agricultural productivity induces a reallocation of labor toward agriculture, the comparative advantage sector (Matsuyama 1992b).

This paper is part of a broader research agenda studying the effects of agricultural productivity on structural transformation in the context of the adoption of GE crops in Brazil. A first study in this agenda, Bustos et al. (2016) shows that, if agricultural technical change is labor-saving, increases in agricultural productivity can lead to a reallocation of labor towards the manufacturing sector, even in open economies. The current paper takes a step forward to understand how the reallocation of workers from agriculture to manufacturing can shape the growth prospects of the industrial sector. First, we document that the introduction of labor-saving agricultural technologies such as GE soy had an asymmetric effect on workers with different skills and thus have an asymmetric impact on industries that use high- and low-skill workers with different intensities. Second, we document that this change in industrial specialization reduces innovation and manufacturing productivity growth.

A second study in this agenda analyzes the effects of the agricultural boom in Brazil on capital markets. Bustos, Garber, and Ponticelli (2020) document that regions with faster technical change in soy experienced an increase in local savings deposits which were not lent locally, leading to an increase in capital outflows. Banks redirected agricultural savings to urban areas outside soy-producing regions where they were invested in the manufacturing and service sectors. Those findings describe the effects of agricultural technical change on structural transformation through a capital supply channel and are consistent with a high level of financial integration across regions. In contrast, the current paper documents the effects of agricultural technical change through a labor supply channel which operates in local labor markets with limited migration responses, thus is consistent with a low level of labor market integration across regions. In section 3.6, we exploit this difference in the levels of labor and capital market integration to separately identify the labor and capital supply channels. Our results show that while former agricultural workers reallocate towards local non-innovative industries, agricultural savings foster the expansion of innovative industries located in other regions, accentuating regional productivity inequalities.

More generally, our paper is related to the classic literature arguing that reallocating agricultural workers into manufacturing can increase aggregate productivity. ${ }^{5}$ First, there might be large static productivity gains when labor reallocates from agriculture to manufacturing. Sizable productivity and wage gaps between agriculture and manufacturing have been measured in several studies and have been shown to be larger in developing economies (e.g., Caselli 2005, Restuccia et al. 2008, Lagakos and Waugh 2013, Gollin,

\footnotetext{
${ }^{5}$ Although this view has been recently challenged by Franck and Galor (2019) who argue, in line with this paper, that the type of industrial specialization is what determines long-run growth.
} 
Lagakos, and Waugh 2014). To the extent that these gaps arise from the existence of inefficiencies and frictions in the economy, a reallocation of labor from agriculture to the other sectors of the economy is both productivity- and welfare-enhancing. ${ }^{6}$ Second, there can be dynamic productivity gains when labor reallocates towards manufacturing if this sector is subject to agglomeration externalities and knowledge spillovers (Krugman 1987, Lucas 1988, Matsuyama 1992a). ${ }^{7}$ Our paper contributes to this literature by showing how manufacturing productivity growth depends not only on the size of the industrial sector but also on its composition.

To make this point, we build on insights from the endogenous growth literature. In particular, the seminal work of Grossman and Helpman (1991) who study open economy endogenous growth models. Their model has two manufacturing industries with different skill intensities that use differentiated intermediates with the same intensity. As a result, incentives for inventing new goods depend on the opportunity cost of performing R\&D, which is driven by the skill premium. Note, however, that in this setup, an expansion of the supply of unskilled workers does not affect innovation and the growth rate of the economy. The reasons is that, if both industries are active in the trade equilibrium, there is factor price equalization and, hence, an increase in the supply of unskilled workers does not affect the skill premium, namely the opportunity cost of innovation, and the growth rate remains constant. Instead, our findings appear to be in line with a modified version of their model in which the incentive to do $R \& D$ depends on the relative size of the two industries, as in Romer (1990).

Our paper also builds on the empirical literature studying the effects of agricultural technical change, particularly those papers that provide evidence that technological advancements in agriculture are skill-biased. For instance, Foster and Rosenzweig (1996) study the effects of the introduction of high-yield varieties in India, and show that technological innovations in agriculture increased the relative demand for skill in agriculture and, thus, returns to primary schooling. ${ }^{8}$ We contribute to this literature by showing that the recent introduction of GE soy was also skill-biased. More importantly, we study the implications of skill-biased agricultural technical change for industrialization, which have not previously been explored. In related contemporaneous work, Imbert, Seror, Zhang,

\footnotetext{
${ }^{6}$ More recently, Herrendorf and Schoellman (2018) measure and compare agricultural wage gaps in countries in different stages of the structural transformation process. They find that the implied barriers to labor reallocation from agriculture are smaller than usually thought in the macro-development literature, and argue that labor heterogeneity and selection are important drivers of such gaps. Other scholars emphasize that structural change can be growth-enhancing or growth-reducing depending on the correlation between changes in employment shares and productivity levels (McMillan and Rodrik 2011 and McMillan, Rodrik, and Sepulveda 2017).

${ }^{7}$ Recent evidence suggests that this channel may be operative in some circumstances. Peters (2019) uses the displacement of Eastern Germans towards Western Germany to show that places experiencing larger population growth specialized in manufacturing and saw GDP per capita grow over the long run.

${ }^{8}$ In related recent work, Bragança (2014) shows that investments in soybean adaptation in Central Brazil in the 1970s induced positive selection of labor in agriculture.
} 
and Zylberberg (2020) exploit short-run agricultural shocks in China to document how migration from rural to urban areas reduces labor costs and makes firms expand labor usage. They find that firms reduce capital-biased technology adoption in response to these labor supply shocks. Differently from Imbert et al. (2020), we focus on technology adoption in agriculture as the factor driving structural transformation, and we study the effects of the reallocation of unskilled workers on industrial specialization through a Hecksher-Ohlin comparative advantage mechanism and its relationship with endogenous growth forces such as innovation investments and their impact on manufacturing productivity dynamics.

The rest of the paper is organized as follows. Section 2 describes the institutional background, the data, and our identification strategy. Section 3 discusses the empirical results. And Section 4, contains our final remarks.

\section{Empirical strategy and data}

Our empirical strategy aims at identifying the effects of one particular "push" factor of structural transformation: the introduction of a new labor-saving technology in agriculture. For this, we exploit the legalization of genetically engineered (GE) soy in Brazil as a natural experiment. We start by providing background information on GE soy in section 2.1. Notice that an increase in the reallocation of labor from agriculture to manufacturing in areas that adopted GE soy could be driven by a shock to labor demand in the local manufacturing sector. This would increase local wages, inducing agricultural firms to switch to less labor-intensive crops, such as soy. Thus, to establish the direction of causality, our identification strategy uses the potential increase in soy yields that can be obtained with GE seeds in each region based on its weather and soil characteristics as a plausibly exogenous measure of technical change in agriculture. We describe this strategy in detail, along with the data used to implement it, in sections 2.2 and 2.3. Finally, in section 2.4, we introduce a new measure of innovation at the microregion level that we use to study the impact of agricultural productivity on innovative activities.

\subsection{Background Information on GE Soy}

The purpose of GE soy seeds is to resist a specific herbicide (glyphosate). The use of these seeds allows farmers to spray their fields with glyphosate without harming soy plants, reducing labor requirements for weed control. ${ }^{9}$ For example, the planting of traditional seeds is preceded by soil preparation in the form of tillage, the operation of removing the weeds in the seedbed that would otherwise crowd out the crop or compete with

\footnotetext{
${ }^{9}$ Other advantages of GE soy seeds are that they require fewer herbicide applications (Duffy and Smith 2001; Fernandez-Cornejo, Klotz-Ingram, and Jans 2002), allow a higher density of the crop on the field (Huggins and Reganold 2008) and reduce the time between cultivation and harvest.
} 
it for water and nutrients. In contrast, planting GE soy seeds requires no tillage, as the application of herbicide selectively eliminates all unwanted weeds without harming the crop. Because activities related to weed control are mostly performed by unskilled workers, the introduction of GE soy seeds tends to displace unskilled labor relatively more than skilled labor.

The first generation of GE soy seeds (Monsanto's Roundup Ready) was commercially released in the U.S. in 1996 and legalized in Brazil in 2003. ${ }^{10}$ Prior to 2003, smuggling of GE soy seeds from Argentina was only detected in 2001 and 2002 according to the Foreign Agricultural Service of the United States Department of Agriculture (USDA, 2001). The 2006 Brazilian Agricultural Census reports that, only three years after their legalization, $46.4 \%$ of Brazilian farmers producing soy were using GE seeds with the "objective of reducing production costs" (IBGE 2006, p.144). According to the Foreign Agricultural Service of the USDA, by the 2011-2012 harvesting season, GE soy seeds covered $85 \%$ of the area planted with soy in Brazil (USDA 2012). ${ }^{11}$

Panel (a) of Figure 1 documents that the legalization of GE soy seeds was followed by a fast expansion of the area planted with soy, which increased from 11 to 19 million hectares between 2000 and 2010. ${ }^{12}$ This graph suggests that the area planted with soy started to increase very rapidly already in 2002. Panel (b) of Figure 1 documents that, in the same period, the number of workers employed in the soy sector decreased substantially. This finding is consistent with the adoption of GE seeds reducing the number of agricultural workers per hectare required to cultivate soy. Bustos et al. (2016) document that labor intensity in soy production fell from 28.6 workers per 1000 hectares in 1996 to 17.1 workers per 1000 hectares in 2006. In addition, the production of soy is less labor-intensive than all other major agricultural activities. According to the Agricultural Census, the average labor intensity of cereals in 2006 was 94.9 workers per 1,000 hectares, 129.8 for other seasonal crops, and 126.7 for permanent crops. ${ }^{13}$ Thus, whenever soy displaced other agricultural activities, labor intensity in agriculture decreased.

Figure 1 goes around here

\footnotetext{
${ }^{10}$ See Law 10.688 of 2003 and Law 11.105 - the New Bio-Safety Law - of 2005 (art. 35).

${ }^{11}$ Note as well that although the initial patent of GE soy seeds was filed in the US by the multinational corporation Monsanto, the final product available in the Brazilian market was the outcome of an adaptation process that involved a Brazilian firm. The year after patenting the Roundup Ready ${ }^{T M}(\mathrm{RR})$ soy seeds in the US in 1996, Monsanto started a collaboration with Embrapa - the Brazilian Research Institute for new agricultural technologies - to develop a version of the GE soy seeds adapted to the agroecological conditions of Brazil. Under this agreement, Embrapa started conducting crossings between the herbicide tolerant variety developed by Monsanto for the US market and seeds previously developed by Embrapa itself for the Brazilian climate. Hence, it necessarily took a few years before GE soy seeds adapted to the Brazilian climate were available.

${ }^{12}$ According to the two most recent agricultural censuses, the area planted with soy increased from 9.2 to 15.6 million hectares between 1996 and 2006 (IBGE 2006, p.144).

${ }^{13}$ According to the 2006 Agricultural Census, even cattle ranching uses more workers per unit of land than soy production (30.6 per 1000 hectares).
} 
In Panel (c) of Figure 1, we decompose the decrease in employment in the soy sector between skilled and unskilled workers, where workers are considered skilled if they have completed at least the $8^{\text {th }}$ grade. As shown, the decrease in employment in the soy sector is entirely driven by low-skilled workers, while the skilled ones were retained. This finding is consistent with GE soy seeds being an unskilled labor saving technology. Notice that in addition to being less labor intensive, soy production is also more skill intensive than most other agricultural activities. As shown in Panel (d) of Figure 1, the share of skilled workers (those completed at least the $8^{\text {th }}$ grade) employed in soy is above 20 percent, while in most other agricultural activities this share ranges between 5 and 15 percent. Thus, whenever soy displaced other agricultural activities, the skill intensity of agriculture increased along with the decrease in labor intensity.

\subsection{Identification strategy}

Our identification strategy builds on Bustos et al. (2016): we exploit the legalization of GE soy seeds in Brazil as a source of time variation and differences in the potential increase in soy yields from the introduction of the new technology across regions as a source of cross-sectional variation. This approach allows us to identify how changes in agricultural technology lead to structural transformation and to study its consequences on local economies.

The potential increase in soy yields due to GE soy seeds is constructed using data on potential soy yields sourced from the FAO-GAEZ database. This dataset reports the maximum attainable yield for a specific crop in a given geographical area. In addition, it reports the maximum attainable yields of each crop under different technologies or input combinations. Yields under the low technology are described as those obtained from planting traditional seeds, with no use of chemicals or mechanization. Yields under the high technology are obtained using improved high-yielding varieties, with optimum application of fertilizers, herbicides, and mechanization.

Following Bustos et al. (2016), we define technical change in soy production as the difference in potential yields between high and low technology. This measure aims at capturing the theoretical change in soy yields obtained by switching from traditional soy production to the use of improved seeds and optimum weed control, among other characteristics. Technical change in soy production in microregion $k$ is therefore defined as:

$$
\Delta A_{k}^{\text {soy }}=A_{k}^{\text {soy,High }}-A_{k}^{\text {soy,Low }}
$$

where $A_{k}^{\text {soy,Low }}$ is equal to the potential soy yield under the low technology and $A_{k}^{\text {soy,High }}$ is equal to the potential soy yield under the high technology. ${ }^{14} \Delta A_{k}^{\text {soy }}$ is our exogenous

\footnotetext{
${ }^{14}$ Although soy farming in certain areas of Brazil was already using relatively advanced techniques
} 
measure of agricultural technical change in agriculture.

Figure 2 shows the geographical variation in this measure of technical change across microregions.

Figure 2 goes around here

The map suggests large variation in agricultural technical change across Brazilian microregions. Some regions, most notably the regions around the Amazon river, and near the South-East coast, experienced little changes in soy productivity. Instead, the regions of the Center-West and South gained substantially from the introduction of the new seed.

With decennial data, we use the following specification to estimate the effect of soy technical change on (long-run) changes in outcomes of interest:

$$
\Delta Y_{k(r)}=\alpha+\beta \Delta A_{k(r)}^{\text {soy }}+\varphi X_{k(r)}+\delta_{r}+\varepsilon_{k}
$$

where $\Delta Y_{k(r)}$ is the change in the outcome of interest in microregion $k$ (located in macroregion $r$ ) between 2000 and 2010 - the years of the last two Population Censuses -, and $X_{k(r)}$ is a vector of controls of microregion $k . \delta_{r}$ indicates macroregion fixed effects that account flexibly for trends across the five major geographical regions of the country: North, Northeast, South, Southeast and Central-West. Our identification strategy relies on the fact that the new GE soybeans seeds were introduced around 2001 or 2002 and legalized in Brazil in 2003, and that this new technology disproportionately favored microregions with certain soil and weather characteristics (as captured by $\Delta A_{k(r)}^{\text {soy }}$ ), something that was not anticipated as of 2000. In all our specifications we include the share of rural population, the initial level of income per capita, the alphabetization rate, and population density at the microregion level, all observed in 1991 and sourced from the Population Census, and the measure of maize technical change (discussed further below and presented in Table A.1 of the Appendix). These controls are meant to flexibly capture differential trends across microregions with different initial levels of income and human capital.

When we analyze the manufacturing sector in detail, we use annual data from RAIS and PIA. This allows us to trace the timing of the effect more precisely by estimating two types of equations. First, to provide visual support to our evidence, we estimate the following dynamic difference-in-differences specification:

$$
\ln y_{k(r), t}=\delta_{t}+\delta_{k}+\delta_{r t}+\sum_{\substack{j=1998 \\ j \neq 2000}}^{2009} \beta_{j} 1[j=t] \Delta A_{k(r)}^{\text {soy }}+\gamma X_{k(r), t}+t \times X_{k(r), 1991}^{\prime} \omega+\varepsilon_{k(r), t}
$$

before the introduction of GE soybeans, our conversations with researchers in charge of the FAO-GAEZ dataset show that GE soy seeds are, in fact, the improved seed varieties used to compute predicted soy yields for Brazil under high inputs. The predictive power of the instrument on GE soy seeds adoption documented in what follows supports this. 
where $\Delta A_{k(r)}^{\text {soy }}$ is the long-run change in our exogenous measure of technical change in soy in microregion $k$, and $\ln y_{k(r), t}$ is an outcome of interest in microregion $k$ at time $t . \beta_{j}$ estimates the effect of the change in the productivity of soy in each year between 1998 and 2009 (using 2000 as our reference year). Thus, we flexibly allow $\beta_{j}$ to capture the effect of soy technical change on the outcomes of interest in each year. This type of specification is informative of the timing and persistence of the effects. $\delta_{k}$ and $\delta_{t}$ are microregion and year fixed effects, respectively. $\delta_{r t}$ are macro-region times year fixed effects. $X_{k(r), t}$ are time-varying controls and $X_{k(r), 1991}$ are the baseline controls discussed above, interacted with a time trend.

With annual data, we estimate the effect of agricultural technical change on manufacturing outcomes using the following specification:

$$
\ln y_{k(r), t}=\delta_{t}+\delta_{k}+\delta_{r t}+\beta A_{k(r), t}^{\text {soy }}+\gamma X_{k(r), t}+t \times X_{k(r), 1991}^{\prime} \omega+\varepsilon_{k(r), t}
$$

where $A_{k(r), t}^{\text {soy }}$ is defined as potential soy yield under high inputs for the years between 2003 and 2009, and the potential soy yield under low inputs for the years between 1999 and 2002 in microregion $k . \delta_{k}$ and $\delta_{t}$ are microregion and year fixed effects, respectively, $\delta_{r t}$ are macro-region flexible trends, and $X_{k(r), t}$ are time-varying controls and $X_{k(r), 1991}$ are baseline controls interacted with a time trend. Hence, $\beta$ is the (continuous) difference-indifferences estimate obtained from comparing microregions before and after 2003. ${ }^{15}$

Table A.1 in the Appendix reports a set of results aimed at validating our measure of soy technical change using data from the 1996 and 2006 Agricultural Censuses. First, in Panel A, we show that our measure of soy technical change strongly predicts variation in the actual adoption of GE seeds by Brazilian farmers across microregions (columns 1 and 2). Importantly, it does not predict the expansion of area farmed with traditional soy (columns 3 and 4). This indicates that this measure of the effect of technical change on potential soy yields is a good proxy of the actual benefits of GE soy adoption given soil and weather characteristics of different areas. Second, in Panel B, we show that our measure of soy technical change predicts the expansion of agricultural area farmed with soy, but not the one farmed with maize, the other main temporary crop which experienced significant technological innovation in this period (columns 1 and 2). ${ }^{16}$ If we build a measure of maize technical change using the same methodology, we find that such measure predicts the expansion in maize area between 1996 and 2006, but not the expansion of soy area (columns 3 and 4). This indicates that our measure of technical change is a good proxy of technological innovation at the crop level. Note that the results reported in Table A.1 effectively replicate the results presented in Bustos et al. (2016) at a larger level of aggregation (microregion instead of municipality).

\footnotetext{
${ }^{15}$ In these specifications, we use a balanced panel of microregions that includes all the microregions for which we have observations in each year of the decade.

${ }^{16}$ See Bustos et al. (2016) for a detailed discussion of second-season maize.
} 


\subsection{Data sources}

In this section, we describe the main datasets used in the empirical analysis. We obtain information on employment from two different sources: the Population Census and RAIS, the social security records dataset of the Ministry of Labor. The Population Census has the advantage of covering both formal and informal workers, and it is available at 10-year intervals. RAIS covers only formal employees, but it has the advantage of being available at the yearly level. We also use data from two different manufacturing surveys: PIA and PINTEC. We use data from PIA - the Brazilian manufacturing survey - to construct measures of manufacturing productivity and capital. We use data from PINTEC - the Brazilian Innovation survey - to classify industries by innovation intensity. In what follows, we describe these four data sources in more detail.

We use the Censuses of 2000 and 2010 to obtain detailed information on employment and wages in all sectors. We focus on individuals with strong labor force attachment. In particular, we include individuals aged between 25 and 55 that work more than 35 hours a week. ${ }^{17}$ Differently from social security data, the Population Census covers both formal and informal workers, which makes it well suited to study movements of workers in the agricultural sector - whose labor force is largely informal - as well as any effect on informal employment in manufacturing. For each individual, we define the sector of occupation as the sector of their main job during the reference week of the census. The Population Census also provides information on the number of hours worked during the reference week and the monthly wage. ${ }^{18}$ We use information on education to categorize individuals as unskilled or skilled. We define workers as skilled if they have completed at least the $8^{\text {th }}$ grade, although our results are robust to alternative definitions of this threshold. This level should be attained when an individual is 14 or 15 years old, and is equivalent to graduating from middle school in the US. We also use data from the Population Census to compute "composition-adjusted" wages (i.e., wages net of observable workers' characteristics). To this end, we estimate a Mincerian regression of log hourly wages on observable characteristics for the two census years of 2000 and 2010, as explained in Appendix B.

The Annual Social Information System (RAIS) is an employer-employee dataset that provides individual information on the universe of formal workers in Brazil. ${ }^{19}$ We use

\footnotetext{
${ }^{17}$ In order to deal with extreme observations, we focus on individuals whose absolute and hourly wages are between the 1st and the 99th percentile for the distribution of wages in their respective year, and who work less than the 99th percentile of hours. Moreover, we only consider individuals not enrolled in the education system at the time of the survey.

${ }^{18}$ We compute hourly wages as the monthly wage divided by 4.33 times the hours worked reference week.

${ }^{19}$ Employers are required by law to provide detailed worker information to the Ministry of Labor. See Decree n. 76.900, December $23^{\text {rd }} 1975$. Failure to report can result in fines. RAIS is used by the Brazilian Ministry of Labor to identify workers entitled to unemployment benefits (Seguro Desemprego) and federal
} 
RAIS to study movements of workers across industries within manufacturing at yearly level from 1998 to 2009. As in the Population Census, we focus on individuals aged between 25 and 55 that work more than 35 hours a week. ${ }^{20}$ RAIS contains detailed information on workers' occupations, which we use to construct the new spatial measure of the labor input in innovation activities described below.

We use data on number of workers, capital, value added, and wage bill from the Annual Industrial Survey (PIA). The PIA survey is constructed using two strata: the first includes a sample of firms with 5 to 29 employees (estrato amostrado), and it is representative at the sector and state level. The second includes all firms with 30 or more employees (estrato certo). We restrict the analysis to firms with 30 or more employees so that our outcomes are representative at the microregion and industry level for those larger firms. We define employment as the end-of-year number of workers, and value added as the difference between value of production and expenditure in intermediate inputs. The PIA survey does not report information on the capital stock. Thus, we use data on investment, depreciation, and the book value of assets in the first year a firm appears on the sample to construct a firm-level measure of capital stock using the perpetual inventory method. For multiplant firms, we allocate capital stock to each of their plants using employment shares. We focus on firms operating in manufacturing as defined by the CNAE 1.0 classification (codes between 15 and 37) and on the period between 2000 and 2009.

Finally, we use data from the Survey of Innovation PINTEC to classify manufacturing industries into $H$ and $L$ industries. We think of $H$ industries as industries that use relatively more skilled labor and dedicate more resources to innovations that can generate knowledge spillovers for other sectors. On the other hand, we think of $L$ industries as traditional, unskilled-labor intensive industries in which the scope for process innovation is lower and that are less likely to generate knowledge spillovers toward other sectors. The PINTEC survey is designed to capture innovation activities of Brazilian firms and it is available every 3 years starting in 2000. Using this data, we construct a measure of R\&D intensity at the industry level, computed as the monetary value of $R \& D$ expenditures divided by total sales in the baseline year 2000. The measure of R\&D expenditure encompasses expenditure in both internal R\&D and external R\&D, as well as expenditure in external know-how, machinery and equipment, training, and expenditures related to introducing innovation in the market. Because this measure subsumes expenditure in components of innovation that might be cataloged as intermediate inputs, we normalize it by total value of output in the industry (sales) rather than value added. ${ }^{21}$

\footnotetext{
wage supplement program (Abono Salarial).

${ }^{20}$ Following Helpman, Itskhoki, Muendler, and Redding (2017), our data cleaning procedure includes: (i) restricting to workers employed as of December 31st in each year; (ii) restricting to the highest-paying job for each worker that appears more than once in the data during one year (randomly dropping ties).

${ }^{21}$ Other papers in the innovation literature that define R\&D Intensity as R\&D expenditures over sales
} 
We define $H$ industries as those above the median level of R\&D intensity, weighting industries by their employment at baseline. Table A.2 reports the full list of manufacturing industries by $R \& D$ intensity and skill intensity. ${ }^{22} R \& D$ intensity and skill intensity at the industry level are highly correlated, as can be seen in Figure A.1 in the Appendix. ${ }^{23}$ Indeed, the production function estimates presented in Table B.12 that we use to compute Total Factor Productivity (TFP) imply that $H$ industries are more skill-intensive, as their skilled labor wage bill share is $18 \%$ while the one for $L$ industries is $13 \%$. In turn, our estimates of the capital share are $77 \%$ and $82 \%$, respectively. This implies that the $L$ industry is slightly more capital-intensive, but given the larger measurement error over this estimate (which is not directly observed as labor payments are but rather inferred as a residual) we think that it is sensible to infer that capital intensity is similar in both industries.

Table 1 reports summary statistics of individual level characteristics observed in the Population Census for workers operating in agriculture, $L$ manufacturing, $H$ manufacturing and services. ${ }^{24}$ As shown, there is large heterogeneity in skill intensity of workers across these broad sectors. Almost 90 percent of workers in agriculture had not completed the $8^{\text {th }}$ grade in 2000, while this number is around 50 percent for manufacturing and services. Large differences are also present within manufacturing, where the share of high-skill workers tends to be higher in $H$ industries, particularly in 2010.

Table 1 goes around here

Table 2 provides summary statistics for the main variables used in the empirical analysis at the microregion level. Microregions are statistical units defined by the IBGE and consist of a group of municipalities. Brazil has 557 microregions, with an average population of around 300,000 inhabitants. We use microregions as an approximation of the local

include, but are not limited to, the seminal papers on the exploration and characterization of industry and firm R\&D Intensity of Pakes and Schankerman (1984), Cohen, Levin, and Mowery (1987), Jaffe (1988) and Cohen and Klepper (1992), and more recent works such as Acemoglu, Akcigit, Alp, Bloom, and Kerr (2018) and Autor, Dorn, Hanson, Pisano, and Shu (2020).

${ }^{22}$ The 60 manufacturing industries reported in Table A.2 correspond to the industry classification CNAE-Domiciliar used in the Population Census. Our original measure of R\&D intensity at industry level constructed using PINTEC data is based on the 4-digit CNAE 1.0 industry classification, which defines 267 different manufacturing industries (PIA and RAIS datasets use the same industry classification). To map the 267 industries in PINTEC with the 60 industries reported in Table A.2 we use the official conversion tables provided by the IBGE (https://concla.ibge.gov.br/).

${ }^{23}$ Notice that data on R\&D expenditure from the PINTEC survey is not representative at the microregion level. Thus, to construct a measure of innovation that is representative at any geographical level, we use the description of occupations reported in the social security records, as described in section 2.4.

${ }^{24}$ We define agriculture, manufacturing and services by following the classification of the CNAE Domiciliar of the 2000 census. Agriculture includes Sections A and B (agriculture, cattle, forestry, and fishing). Manufacturing includes Section D, which corresponds to the transformation industries. Services include: construction, commerce, lodging and restaurants, transportation, finance, housing services, domestic workers, and other personal services. We exclude the following sectors because they are mostly under government control: public administration, education, health, international organizations, extraction, and public utilities. 
labor market of a Brazilian worker. They can be thought of as small, open economies that trade in agricultural and manufacturing goods but where production factors are immobile. ${ }^{25}$ For outcomes sourced from the Population Census, which are observed in 2000 and 2010, we report the mean and standard deviation of their level in the baseline year (2000) and of their change between 2000 and 2010.

Table 2 goes around here

\subsection{A new measure of innovation across space}

Testing the impact of agricultural productivity on innovative activities requires to observe innovation at the microregion level, our unit of observation in the empirical analysis. For this purpose, we develop a new measure of innovation which is representative at any level of geographical disaggregation, using the description of occupations in RAIS. More specifically, we propose a new measure of the labor input in innovation activities based on textual analysis of the task descriptions of more than 2,500 occupations. Tasks generating innovations include, for example, developing new products and processes, creating prototypes, or optimizing methods of production. An important advantage of this measure is that it allows us to track innovation workers across sectors and regions. This is because the social security data covers the universe of formal firms. In contrast, standard manufacturing innovation surveys, such as PINTEC, are based on a sample of firms that is not representative at low levels of geographical disaggregation, and do not allow to trace workers' movements across firms.

In what follows, we describe our methodology to identify workers in innovative occupations. As a first step, we digitized the text containing the official description of the tasks associated with each occupation as provided in the "Brazilian Classification of Occupations" published by the Ministry of Labor. In the second step, we defined a set of 39 keywords or combination of keywords capturing tasks related to innovative activities. To generate this list, we identified a set of words that are used to define activities related to innovation either in the task description of occupations provided by the Ministry of Labor, or in the technical documentation of PINTEC, the Survey of Innovation of Brazilian firms. The list of keywords used is reported in Appendix Table A.3. As shown, most entries are a combination of a verb and a noun describing a task associated with innovation. These combinations can be grouped in those capturing innovation of products (e.g. "develop/improve product/s"), innovation of processes (e.g. "develop/improve/test process/es"), innovation of machinery and equipment (e.g. "develop device/s", "develop equipment"). We also include single nouns, combinations of nouns, or combinations of

\footnotetext{
${ }^{25}$ In Table A.5 of the Appendix we show that internal migration did not respond to the shock. This is in line with evidence from Brazil's lack of internal migration responses documented also in Dix-Carneiro and Kovak (2019) and Costa, Garred, and Pessoa (2016).
} 
nouns and adjectives that are often found in the description of innovation intensive tasks (e.g. "innovation", "prototypes", "research and development", "new technologies"). Finally, in the last step, we run a text analysis that identifies all occupations whose description contains at least one of the keywords listed in Appendix Table A.3. This methodology identifies 251 occupations, which we define as innovation-intensive. ${ }^{26}$

Figure A.2 shows the total number and the share of manufacturing workers in innovationintensive occupations in Brazil. According to our measure, the number of workers in innovation-intensive occupations increased from approximately one hundred thousand in 2000 to three hundred thousands in 2014, and started falling afterward when Brazil entered into a severe recession. Workers in innovation intensive occupations constitute between 3 and 4 percent of total manufacturing formal employment. This share has been increasing during the period under study from 2.5 percent in the early 2000s to slightly above 4 percent in most recent years. ${ }^{27}$ Figure A.4 reports the share of local manufacturing employment engaged in innovation intensive activities in each microregion of Brazil in the baseline year 2000. As shown, the share of innovation workers ranges from 0 to almost 20 percent of formal manufacturing employment, with higher shares observed in the coastal regions of the South and South-east of Brazil, but also in several microregions encompassing large cities in the North and Center-West regions of the country.

We perform a set of consistency tests on our measure of innovation. Figure A.3 shows the correlation between employment share in innovation-intensive occupations and other measures of innovation that are available at the industry level from the PINTEC survey. We include measures that capture the amount of inputs devoted to the innovation process - such as R\&D expenditure per worker - as well as measures capturing the output of the innovation process - such as the share of firms in a given sector that have filed patents and the share of firms that have introduced new processes or products. As shown, the share of innovation-intensive workers is highly correlated with all these alternative measures, with the additional advantage of being available not only at the sector level but also at fine levels of geographical aggregation. Table A.4 reports the magnitude of the correlations between the share of innovation-intensive workers in each industry and the alternative measures reported in Figure A.3. The estimates indicate that a 1 percentage point increase in the share of innovation-intensive workers in a given industry is associated with a 6 percent increase in $R \& D$ expenditure over sales, a 1.6 percentage point increase in the share

\footnotetext{
${ }^{26}$ See Lagaras (2017) for an application of this methodology at the firm-level in order to explore the impact of corporate acquisitions on labor reorganization and firm-level innovation.

${ }^{27}$ The Brazilian Ministry of Labor has updated its classification of occupations in 2002. RAIS uses the new classification (CBO2002) starting from 2003. We identify innovation intensive occupations using the the description of tasks provided for the CBO2002 classification. To extend our analysis to the pre-2003 years we match the old classification (CBO 1994) and new classification (CBO 2002) using the official correspondences provided by the Ministry of Labor. Whenever one occupation in the old classification is matched with multiple occupations in the new one, we weight the number of workers in that occupation by the share of innovation workers observed in the first year in which the new classification is used (2003).
} 
of firms filing for patents, and a 1.6 percentage points increase in the share of firms introducing either a new product or a new process.

We also want to discuss in more detail the differences between the measure of innovation based on workers' task description proposed in this paper and the main alternative measure of innovation used in the literature: patenting. One advantage of patent data is that it captures the output of the innovation process, and - by using patent citations - it allows researchers to make statements about the quality of the innovation produced (Carlino and Kerr 2015). However, an important disadvantage of patent data is that, in many instances, firms introduce new products or processes without patenting them. Data from PINTEC, shows that, in the decade 1997 to 2008, 34 percent of surveyed firms introduced new processes or products. However, only 7 percent of those firms have filed a patent application or have an approved patent for such innovation. ${ }^{28}$ This fact is visible also in panel (f) of Figure A.3, which shows how in many sectors with a high share of firms introducing new processes and products, no firms report patenting activity. The fact that many firms decide not to patent their innovations has been documented also in other countries. For example, Cohen, Nelson, and Walsh (2000) analyze survey data from approximately 1,500 R\&D labs of manufacturing firms in the US, and show that patenting is used less frequently than other approaches to protect the return from invention, as patent applications require firms to disclose to competitors a large amount of information. According to the same survey, smaller firms tend not to apply for patents due to their legal costs, and are also more likely to consider patents ineffective.

Finally, we want to clarify that what our measure of innovation intends to capture is not just investment in R\&D that pushes the world technology frontier, but also investment in adapting innovations developed elsewhere to the Brazilian market or to firm-specific production processes. Indeed, aggregate data from the PINTEC suvey indicate that most innovations introduced by Brazilian firms happen through adaptation of technologies that are new to the firm but already in use elsewhere. In particular, about $84 \%$ of new products and $94 \%$ of new processes introduced by Brazilian firms surveyed in PINTEC are an innovation for the firm but already exist in some form either in Brazil or in the rest of the World. ${ }^{29}$ In this sense, we think of investments aimed at "adapting" a new technology developed elsewhere to the Brazilian market, and making it usable for local firms, as an investment in innovation.

\footnotetext{
${ }^{28}$ These statistics are based on Table 6497 of the PINTEC surveys run in 2000, 2003, 2005 and 2008. Each PINTEC survey captures the innovative activities in the previous three years, so they effectively cover the decade 1997 to 2008. The statistics reported are averages across the four waves.

${ }^{29}$ The case of GE soy is illustrative in this respect. While the initial patent of GE soy seeds was deposited in the US by the multinational corporation Monsanto, the final product available in the Brazilian market was the outcome of an adaptation process that involved Embrapa - the Brazilian Research Institute for new agricultural technologies. In particular, Embrapa conducted a series of crossings between the herbicide tolerant variety developed by Monsanto for the US market and seeds previously developed by Embrapa itself to develop a version of the GE soy seeds adapted to the agro-ecological conditions of Brazil.
} 


\section{Results}

\subsection{Industrialization without productivity growth}

We start by studying the effect of soy technical change on the reallocation of workers and capital towards manufacturing and then study its impact on manufacturing productivity growth. To this end, we use data on employment from the Population Census and social security records (RAIS), and data on capital from the annual manufacturing survey (PIA).

The results are reported in Table 3. In Panel A, we study the effect of soy technical change on labor reallocation across sectors using Census data and the ten year first-difference specification explained in section 2.2, equation (1). We find that microregions with higher exposure to soy technical change experienced a decrease in the share of workers employed in agriculture and an increase in the share of workers employed in manufacturing and services. ${ }^{30}$ The magnitude of the estimates indicates that agricultural workers displaced by the new technology relocated mostly into manufacturing: microregions with a one standard deviation larger increase in soy technical change experienced a 2.4 percentage points larger decline in the agricultural employment share, a 1.8 percentage points increase in the manufacturing employment share, and a 0.6 percentage points increase in the services employment share. Overall, these results indicate that soy technical change was labor-saving and led to structural transformation, which are the main findings documented in Bustos et al. (2016). ${ }^{31}$

Table 3 goes around here

In Panel B, we move to data from the manufacturing survey (PIA), which allows us to use a yearly panel of microregions. We estimate the specification discussed in section 2.2 , equation (3), using as outcome variable the total number of workers in manufacturing in a given microregion and year (in logs). The estimated coefficient shows that microregions more exposed to soy technical change experienced a larger increase in manufacturing

\footnotetext{
${ }^{30}$ Soy technical change had only small and not significant effects on total employment. Thus, the employment changes that we document in what follows are not driven by migration between microregions or by changes in the total number of workers employed, but by movement of workers across sectors within microregions. Table A.5 provides evidence on the effect of soy technical change on total employment and migration.

${ }^{31}$ Bustos et al. (2016) find that soy technical change had a positive and significant effect on the employment share in manufacturing but no significant effect on the employment share in the services sector. Panel A of Table 3 in this paper documents that microregions more exposed to soy technical change experienced an increase in employment share in both manufacturing and services. There are two reasons behind this difference in results when the outcome is the employment share in the services sector. The first is that, in this paper, we focus on remunerated labor - i.e. workers receiving a wage - whereas Bustos et al. (2016) also included workers who helped household members without receiving a payment or worked in subsistence agriculture. The second is the unit of observation, which is a microregion in this paper, a municipality in Bustos et al. (2016).
} 
employment. The magnitude of the coefficient indicates that a one standard deviation differential change in soy technical change leads to a 7 percent larger increase in manufacturing labor. Next, we investigate whether soy technical change also affected capital investment by manufacturing firms. The results are reported in column (2), and show that capital also moved towards manufacturing. The estimates suggest that a one standard deviation differential change in soy technical change leads to an increase in capital in the manufacturing sector of around 17.6 percent.

In columns (3) to (5), we study the effect of soy technical change on manufacturing productivity. We construct three measures of productivity using data from the manufacturing survey PIA: value added per worker, valued added over wage bill, and total factor productivity. ${ }^{32}$ The results show that, although both labor and capital reallocated towards manufacturing, regions more exposed to soy technical change experienced a relative decline in manufacturing productivity. The magnitude of the coefficient in column (3) indicates that labor productivity declined by about 10 percent for a standard deviation differential change in soy technical change, which correspond to about 1.5 percent lower growth rate in manufacturing productivity in the post GE legalization period. We find similar magnitudes for alternative measures of productivity computed as value added per wage bill or total factor productivity.

Taken together, the results presented in Table 3 indicate that, despite the fact that soy technical change drove factors of production from agriculture towards manufacturing, productivity in manufacturing slowed down in the years following GE soy legalization. In the next sections, we explore the mechanisms that can rationalize this result. In particular, we document the skill composition of the workers moving into manufacturing, the patterns of industrial specialization, and how they may have influenced innovation activities.

\subsection{Unskilled-labor saving agricultural technical change}

We start by studying the impact of GE soy technical change on workers with different skills using data from both the Population Census and social security records (RAIS). Table 4 presents the results using Census data. We estimate the ten year first-difference specification presented in equation (1), and use as outcome variables the changes in the share of unskilled and skilled workers in agriculture, manufacturing and services between

\footnotetext{
${ }^{32}$ We compute total factor productivity as the Solow residual of a Cobb-Douglas production function that combines skilled labor, unskilled labor, and capital in a constant returns to scale fashion. We calibrate the factor shares for skilled and unskilled labor by computing, for each type of labor, the aggregate wage bill divided by total value added in Brazil in 2000, 2001, and 2002 and then taking the average across years. The capital share is calibrated by leveraging the constant returns to scale assumption. These assumptions imply that for a given industry the production technology is the same across microregions and periods, and thus, changes in the TFP are dictated by changes in the allocation of production factors. See Appendix B.1 for a more detailed explanation of how the TFP measure is computed.
} 
2000 and 2010.

Columns (1) to (3) focus on unskilled workers. We find that microregions more exposed to soy technical change experienced a reallocation of unskilled workers from agriculture to manufacturing. The magnitude of the estimated coefficients indicates that microregions with a standard deviation higher increase in soy technical change experienced a 2.4 percentage points larger decrease in the share of low-skilled workers employed in agriculture, and a corresponding 2.2 percentage points larger increase in the share of low-skilled workers employed in manufacturing. These magnitudes correspond to a 7.2 percent decrease in the initial share of low-skilled workers employed in agriculture and a 16.1 percent increase in the share of those employed in manufacturing. Combined with the fact that soy technical change had no differential effect on total employment (see Table A.5 in the Appendix), these results are consistent with a decline in the absolute demand for low-skill labor in agriculture in response to skilled labor-augmenting technical change.

Columns (4) to (6) focus instead on skilled workers. We find that microregions more exposed to soy technical change experienced a larger decrease in the share of high-skill workers in agriculture, and a larger increase in the share of high-skill workers employed in manufacturing, as expected if low and high-skill workers are to some extent complementary in production. In terms of magnitude, the effect of soy technical change on low-skill labor is about twice as large as the effect on high-skill labor.

Table 4 goes around here

Next, we explore in more detail the labor reallocation process described above using yearly social security data from RAIS. Although RAIS data captures only formal employment, its annual frequency allows us to check whether the employment changes documented with Census data occurred right after GE soy was introduced in Brazil. For this, we plot the interaction of year dummies with our measure of soy technical change as explained in Section 2.2, see equation (2). As can be seen in Figure 3 (a), low-skilled labor started to move towards manufacturing in microregions more exposed to soy technical change around 2002, while there is no systematic difference in the trends leading to this year. When focusing on formal employment captured by social security data, we find no differential increase in skilled labor moving towards manufacturing, as shown in Figure 3 (b). The timing of the effect suggests that changes were permanent. Reallocation of unskilled labor towards manufacturing started around 2002, one year after the first reported smuggling of the GE soy seeds in Brazil and the year when the area planted with soy started expanding at a faster rate (Figure 1). The reallocation then accentuated around 2004, one year after the formal legalization of GE soy in Brazil, and stabilized during the second half of the decade. 
Finally, we investigate the effect of agricultural technical change on wages. As the adoption of GM soy reduces unskilled-labor demand, we would expect a reduction in unskilled worker wages in exposed local labor markets. However, identifying the effect of the new technology on wages is particularly challenging in this context for two reasons. First, the new technology generated a large reduction in agricultural employment which concentrated among workers with low levels of education and possibly other unobserved measures of human capital. Thus, workers remaining in agriculture are likely to be positively selected and display higher wages. We cannot directly address this concern by controlling for worker unobserved characteristics (fixed effects) because the Population Census does not allow to follow workers over time, and the social security data is not representative of agricultural employment due to high levels of informality in this sector. Second, the minimum wage nearly doubled in real terms during the decade under study, increasing from $\mathrm{R} \$ 266$ in February 2000 to $\mathrm{R} \$ 510$ in January 2010 (Berg, 2010). We address this is a potential confounding effect by studying the impact of GM soy on the share of workers at the minimum wage in each local labor market.

We start by discussing the evidence on wages shown in panel A of Table A.6, displayed in the Appendix. The wage premium for high-skill workers increased uniformly across sectors, which is consistent with a relative increase in the demand for high-skill labor and fluid mobility of workers across sectors over the time horizon of our study. However, we also find that composition-adjusted average wages of both high and low-skill workers in agriculture increased. As mentioned above, the increase in low-skill wages is probably the result of selection on unobservables. ${ }^{33}$ In addition, panels $\mathrm{B}$ and $\mathrm{C}$ show that the skill premium increase in manufacturing and services is a result of higher wages of highskilled workers but no changes in the wages of low-skilled workers. This finding leads us to investigate whether wage reductions were constrained by the large contemporaneous increase in the minimum wage. Table A.7 shows that the share of workers at the minimum wage increased more in microregions with faster soy technical change: a one standard deviation increase in potential soy yields leads to a $13 \%$ increase in the share of workers at or below the minimum wage. This large effect suggests that if minimum wages had not increased, the reallocation of unskilled workers toward the manufacturing sector would have depressed wages.

Taken together, the estimates presented in Table 4 and Figure 3 show that the agricultural sector experienced a decrease in its employment share of both low-skill and highskill labor, while the manufacturing sector experienced an increase in employment driven mainly by low-skill labor. These findings indicate that labor-saving technical change in

\footnotetext{
${ }^{33} \mathrm{We}$ come back to this point in Section 3.4, when we investigate and reject the possibility that the bulk of the decline in manufacturing productivity documented in the previous section is explained by this negative worker selection.
} 
agriculture driven by the adoption of GE soy was skill-biased and led mainly low-skill workers to reallocate towards manufacturing.

\subsection{Industrial specialization}

From the point of view of the manufacturing sector, the inflow of former agricultural workers documented in Section 3.2 amounts to an increase in the (relative) supply of unskilled labor. According to the classic Heckscher-Ohlin trade model this generates a comparative advantage in unskilled-labor intensive industries, which should expand by absorbing the inflow of unskilled workers and also attract other complementary factors such as capital and skilled labor (Rybczynski, 1955). Because low-skill industries are characterized by low R\&D-intensity, factor reallocation towards them can potentially explain the decline in manufacturing productivity. To assess these mechanisms, in this section, we investigate which type of industries expanded and absorbed the labor released from agriculture.

To study the effects of soy technical change on industrial specialization we use the classification of manufacturing in $H$ and $L$ industries based on PINTEC data described in section 2.3. $H$ industries are defined as those with higher than median R\&D intensity and tend to use skilled labor more intensively. We start by documenting the effect of soy technical change on industrial specialization using population census data, by estimating equation (1). Panel A of Table 5 shows that the labor inflow into manufacturing is concentrated in $L$ industries whose employment expanded by around 17 percent for a one standard deviation differential increase in potential soy yields. In contrast, $H$ industries did not experience any differential change in employment. In Panel $\mathrm{B}$, we investigate industrial specialization using social security data and the yearly panel regression introduced in equation (3). The results are in line with the ones obtained with Population Census data: labor was absorbed by $L$ industries. Point estimates are smaller possibly due to the fact that social security data only includes formal labor. As the level of informality is higher in agriculture than manufacturing, it is possible that former agricultural workers were more likely to accept informal contracts. In this case, their employment in the manufacturing sector is captured by the Population Census but not by social security data.

Next, we investigate the effects of agricultural technical change on capital investment in manufacturing. We highlight two potential channels through which agricultural productivity growth can lead to capital investment in manufacturing. First, a labor supply channel: the labor inflow in the $L$ industry documented above would tend to increase the marginal product of capital, which should attract more investment into this industry. Second, a capital supply channel: high agricultural productivity increased local savings, as documented in Bustos et al. (2020). In turn, this increase in local capital supply 
could have increased capital investment in capital-intensive industries. Panel C of Table 5 shows that capital inflows to manufacturing concentrated in $L$ industries, where capital increased by 26.7 percent for a one standard deviation differential change in soy technical change. In contrast, $H$ industries did not experience these capital inflows. Hence, this evidence, combined with the fact that our production function estimates imply that both industries have a similar capital-intensity (see Section 2.3), seems to favor the labor supply explanation.

Table 5 goes around here

To investigate in more detail the timing of these labor and capital inflows into manufacturing, we estimate the dynamic difference-in-differences specification described in equation (2). The coefficient estimates are presented in Figure 4, which shows that the adoption of GM soy induced the reallocation of labor towards $L$ industries starting in 2002. This timing coincides with the first reports of large scale smuggling of GE soy seeds and the expansion of the area planted with soy (Figure 1) in 2002, which led to the legalization of the new soy seeds in 2003. In addition, the figure shows that labor inflows into manufacturing precede capital inflows by one year, which is further evidence in support of the labor supply mechanism discussed above. We return to this point in Section 3.6 where we investigate the capital supply mechanism in more detail.

Figure 4 goes around here

In sum, we find evidence of local industrial specialization into $L$ industries. This finding is consistent with Rybczynski-type forces (Rybczynski, 1955), since the labor released from agriculture was mainly low-skilled and that $L$ industries tend to use lowskilled labor more intensively. In what follows, we investigate how this pattern of industrial specialization can explain the decline in manufacturing productivity.

\subsection{Manufacturing productivity}

In this section, we investigate the causes of the manufacturing productivity decline documented in section 3.1. First, we document the dynamics of the effect of soy technical change on manufacturing productivity using two alternative measures of productivity: value added per worker and TFP. To this end, we estimate the yearly effect of soy technical change using the specification described in Section 2.2, equation (2). As shown in Figure 5 (a) and (b), the yearly estimates show a small and non-significant effect of soy technical change on manufacturing productivity up to around 2004, when the point 
estimates become negative and statistically significant. Thus, the timing of the manufacturing productivity decline is consistent with the timing of legalization of GE soy seeds in Brazil and the reallocation of workers and capital into $L$ industries documented in the previous section.

The findings discussed above suggest two potential explanations of the productivity slowdown. First, as low R\&D industries tend to be less productive (and invest less in innovation), the mere reallocation of factors into these industries can reduce the overall level of manufacturing productivity (and its growth rate). Second, the increase in the size of the low R\&D industry can change incentives to innovate in both industries, affecting productivity growth within each of them. To assess the relative importance of each of these mechanisms, we start by decomposing the total effect of soy technical change on manufacturing productivity in three components: changes in productivity within the $L$ industry, changes in productivity within the $H$ industry, and the change in productivity driven by reallocation of factors between industries. In particular, we use the following decomposition:

$$
\begin{gathered}
\Delta \log T F P_{i t}=\underbrace{s_{i L t} \times \Delta \log T F P_{i L t}}_{\text {Change within } L \text { industry }}+\underbrace{\left(1-s_{i L t}\right) \times \Delta \log T F P_{i H t}}_{\text {Change within } H \text { industry }}+ \\
+\underbrace{s_{i L t} \times \Delta \log \omega_{i t} \times \frac{\left(T F P_{i L t}-T F P_{i H t}\right)}{T F P_{i L t}}}_{\text {Composition effects }}+\varepsilon_{i}
\end{gathered}
$$

where $s_{i L t}=\frac{\omega_{i} \times T F P_{i L t}}{\omega_{i} \times T F P_{i L t}+\left(1-\omega_{i}\right) \times T F P_{i H t}}$ corresponds to the share of TFP in the L industry weighted by $\omega_{i}=\frac{V A_{i L, 2000}}{V A_{i L, 2000}+V A_{i H, 2000}}$ which is the value added share of each sector in 2000, before the adoption of the new GE soy seeds. ${ }^{34}$ The first and second terms of this equation reflect changes in manufacturing productivity within the $L$ and $H$ industries, respectively. The last term captures changes in overall manufacturing productivity due to composition effects, driven by changes in the relative size of each industry.

The decompositions into between and within components, using value added per worker and our measure of TFP, are reported in Figure 5, graphs (c) and (d). Both graphs show that most of the reduction in the level of manufacturing productivity is driven by the within components, the between component being small. In fact, the estimates imply that the "between" component can explain at most 8 percent of the overall decline in manufacturing productivity. Hence, most of the manufacturing productivity decline is not driven by a change in the relative size of each industrial sector.

\footnotetext{
${ }^{34}$ Notice that $\varepsilon_{i t}$ is a residual that comes from the fact that we use pre-shock weights and aggregate differences in TFP between sectors, rather than microregion specific ones.
} 
Figure 5 goes around here

Table 6 quantifies further the results shown in Figure 5. The estimated coefficients in columns (1), (2), and (3) indicate that microregions with a one standard deviation faster technical change in soy experienced a decline in manufacturing productivity in the $L$ industry of between 10 and 11 percent when using value added per worker or value added over wage bill as measures of productivity, and of about 23 percent when using TFP. The declines in manufacturing productivity in the $\mathrm{H}$ industry are between 9 and 11 percent for a standard deviation difference in soy technical change across all measures of productivity.

The large reductions in productivity within the $L$ industry reported above, in the context of an overall increase in the size of this industry, have important implications for interpreting the evidence. First, this finding confirms that capital and labor are not pulled into the $L$ industry by increases in its productivity but pushed by labor-saving technical change in agriculture. Second, the resulting larger scale of this industry does not appear to generate increasing returns. To further our investigation, in what follows we evaluate two potential explanations for the observed decline in manufacturing productivity: worker composition and lower returns to innovation.

We start, in this section, by considering whether a composition effect driven by the entry of low-productivity former agricultural workers could contribute to the decline in productivity within the $L$ industry. This explanation is plausible because agricultural technical change appears to have displaced the low skill workers with lower wages, as discussed in Section 3.2. Then, workers entering manufacturing appear to be negatively selected both in observable characteristics such as education and unobservable characteristics such as their level of ability. Still, further evidence suggests that worker selection's contribution to $L$ industry manufacturing productivity decline is quantitatively small. First, when we look directly at the educational skill composition in the $L$ industry we do not find any significant change as a result of soy technical change (Table A.8). Second, some of our measures of productivity, such as value added over wage bill, are designed to account not only for observable differences in workers' human capital like education, but also for differences that are unobservable to the econometrician but not to the firm and thus captured by wages. To see this, note that we can decompose labor productivity in $L$ industries as valued added per wage bill and average wages: $\ln V A / L=\ln V A / w L+\ln w$. In perfectly competitive labor markets, average wages should reflect the average marginal product of labor, which can be tied to productivity. In this case, negative worker selection would manifest in a decline in average wages and, hence, large differences in our estimates of the effect of soy technical change on manufacturing productivity measured as value added per worker and as value added per wage bill, shown in Table 6. Yet, the estimates in columns (1) and (2) of this table are very similar, implying that at most $11 \%$ of the 
decline in manufacturing productivity in the $L$ industries can be attributed to worker selection. $^{35}$

Table 6 goes around here

Finally, it is worth emphasizing that a composition effect driven by low-productivity entrants could contribute to the decline in productivity within the $L$ industry, but it should not affect the productivity of the $H$ industry, because the latter does not absorb agricultural workers. However, as shown in Table 6, manufacturing productivity declines in both the $L$ and the $H$ industries, and by comparable magnitudes. This finding suggests that the reduction in manufacturing productivity could be driven by changes in the return to perform innovation activities in both industries, a possibility we explore in detail in the following section.

\subsection{Innovation}

In this section, we investigate whether the simultaneous reduction in productivity within $L$ and $H$ industries can be explained by changes in innovation activities. A major challenge to studying the response of industrial innovation to agricultural technical change is the lack of a measure of investment in $R \& D$ which is representative at low levels of spatial aggregation such as micro-regions. Thus, as detailed in Section 2.3, we use the description of workers' occupations in social security data to develop a new measure of investment in innovation that varies both across regions and sectors. We measure the labor input in innovation as the total wage bill of workers in innovation-intensive occupations, which are defined as those effectively producing new ideas - such as new products and processes - within each industry.

This measure allows us to estimate the effect of agricultural technical change on the allocation of innovative activities across industries. In particular, we estimate equation (2) using as outcome variable the total wage bill of workers employed in innovation and non-innovation intensive occupations and report estimates in Figure 6. The top panels (a) and (b) confirm that regions more exposed to soy technical change experienced an increase in the wage bill in non-innovative activities within $L$ industries. In turn, panels (c) and (d) report the effect of agricultural technical change on investment in innovation-intensive activities. Estimates reported in panel (c) show that, if anything, innovative activities in $L$ industries increased slightly. In turn, estimates in panel (d) show that regions more exposed to soy technical change experienced a sharp decline in investment in innovative activities within $H$ industries, whose timing corresponds with the legalization of GE soy in 2003.

\footnotetext{
${ }^{35}$ This number results from the following calculation: $(0.151-0.135) / 0.151=0.106$.
} 
Figure 6 goes around here

Table 7 quantifies the effects documented in Figure 6. The coefficients reported in columns (1) and (2) confirm that microregions with a one standard deviation larger increase in potential soy yields experienced an 11 percent higher increase in the wage bill of non-innovative labor in $L$ industries and no increase in $H$ industries. In turn, column (3) shows a positive but not statistically significant increase in the wage bill of innovative labor in $L$ industries. Finally, column (4) shows that microregions with one standard deviation larger increase in soy technical change experienced a 20 percent larger decline in the wage bill of innovative labor in $H$ industries.

Table 7 goes around here

The findings discussed above suggest that the increase in the relative size of the $L$ industry reduced innovation incentives within the $H$ industry. To better understand the connection between growth in the $L$ industry and the reduction in innovation in the $H$ industry, we perform two additional exercises. First, we want to understand whether the decline of innovation in the $H$ industry is driven by lower entry or lower retention of workers that might be attracted to the L industry. We use social security data to classify innovation workers employed in the $H$ industry into five different categories: stayers (i.e. innovation workers already observed in the previous year in the $H$ industry), entrants in the labor market, entrants from informality/self-employment/unemployment, switchers from $L$ industries and switchers from sectors other than the $L$ industry. We then estimate the impact of soy technical change on the wage bill of each of these categories separately. The results are reported in Figure 7. As shown, in regions more exposed to soy technical change, innovation workers are both less likely to enter and to stay in the $H$ industry. The magnitude of the effect on the different components indicates that about half of the total effect is driven by a lower probability of innovation workers remaining in the $H$ industry. The other half is driven by lower entry into the $H$ industry in regions more exposed to soy technical change.

Figure 7 goes around here

Next, we follow the employment trajectories of innovation workers to investigate to what extent lower retention in the $H$ industry is due to worker reallocation to the $L$ industry. To this end, we identify all workers employed for at least one year in innovation activities in the $H$ industry in the baseline period before the legalization of GE soy seeds, i.e. 1998 to 2002 . Then, we track the employment trajectories of these workers and 
identify those who moved to $L$ industries. This allows us to measure the effect of soy technical change on the share of innovation workers initially employed in the $H$ industry that reallocated to the $L$ industry in each microregion and year. Figure 8 (a) reports results using the wage bill share of those workers as an outcome. As shown, we find a positive and significant effect in the post 2003 period. This implies that in microregions with a one standard deviation higher exposure to soy technical change 2.4 percentage points of the wage bill share of innovation workers is lost due to reallocation of workers towards the $L$ industry over the whole post-period. We can use this estimate to calculate the share of the overall reduction in innovation expenditures in the $H$ industry $(20 \%$ for one standard deviation higher exposure to soy technical change) that is directly due to reallocation of workers to the $L$ industry. As mentioned above, half of this reduction is explained by lower worker entry and the other half by lower retention of workers. We focus our calculations on this second half as we can only track the employment trajectories of workers who were initially in the $H$ industry. Then, out of the reduction in innovation expenses due to less retention of workers in $H(10 \%)$, direct reallocation to $L$ explains $24 \%$.

Note that we cannot give a direct estimate of how much of the total reduction in innovation wage bill in $H(20 \%)$ is due to worker reallocation to $L$, because we cannot identify individuals that decide not to enter the $H$ industry but would have entered in the absence of soy technical change. Still, we can make a back of the envelope calculation by extrapolating our estimate for the workers who moved from the $H$ to the $L$ industry. This calculation implies that the expansion of the $L$ industry explains $24 \%$ of the overall reduction in innovation expenditures in the $H$ industry. We can think of this estimate as a lower bound to the extent that new entrants are more likely to be attracted to $L$ than workers already employed in the $H$ industry due to labor market frictions. ${ }^{36}$

Finally, we study whether innovation workers reallocating to the $L$ sector also experienced a change in occupation. As in the previous exercise, we focus on the innovation workers initially observed in $H$ industries, and study what fraction of those who moved to $L$ industries remained employed in innovation intensive occupations when changing industry, and which fraction instead changed to non-innovation intensive occupations. The results of this decomposition are shown in Figure 8 (b) in terms of wage bill and in Figure A.5 (b) in terms of number of workers. As shown, in both decompositions we find that more than one-third of innovation workers moving from $H$ to $L$ industries also changed occupation, switching from an innovation-intensive to a non-innovation intensive job.

Taken together, the results presented in this section show a decline in innovative

\footnotetext{
${ }^{36}$ Figure A.5 (a) reports the same exercise using the share of innovation workers initially employed in the $H$ industry that reallocated to the $L$ industry as an outcome (rather than their wage bill). The magnitude of the estimated effects indicate that microregions with one standard deviation higher exposure to soy technical change had a 1.5 percentage points higher share of innovation workers initially employed in the $H$ industry that relocated towards the $L$ industry.
} 
activities performed in $H$ industries in regions more exposed to agricultural technical change, and a reallocation of such activities from $H$ to $L$ industries. In addition, the results indicate that a significant fraction of innovation workers moving to $L$ industries also switched from innovation intensive to non-innovation intensive occupations. These results can explain the decline in manufacturing productivity growth that accompanied the industrialization process in such regions. In particular, the results suggest that the decline in innovation within $H$ industries reduced local knowledge production, causing manufacturing productivity growth to decline in both industries. Note that lower innovation in the $H$ industry appears to have a direct effect on its productivity and an indirect effect on the productivity of the $L$ industry through local knowledge spillovers.

\subsection{The role of capital}

In section 3.3, we documented that the reallocation of agricultural workers into lowR\&D intensive manufacturing industries was followed by an inflow of capital. We evaluated two potential channels through which agricultural productivity growth can lead to capital investment in manufacturing. First, a labor supply channel: labor-saving technical change in agriculture generated an inflow of workers in the $L$ industry. Larger employment is expected to increase the marginal product of capital and thus attract more investment into this industry. Second, a capital supply channel: high agricultural productivity increased local savings, as documented in Bustos et al. (2020). In turn, this increase in local capital supply could have increased capital investment in capital-intensive industries. We concluded that the evidence presented in that section favoured the labor supply mechanism for two reasons. First, capital inflows into manufacturing lagged labor inflows by one year. Second, capital inflows were concentrated in $L$ industries while both industries have a similar capital-intensity. Still, in the current section we conduct a more detailed exploration of the capital supply channel.

We build on previous work studying the effects of the agricultural boom in Brazil on capital markets. Bustos et al. (2020) document that regions with faster technical change in soy experienced an increase in local savings deposits which were not lent locally, leading to an increase in capital outflows. They use detailed credit registry data to track the destination of capital flows and find that banks capturing deposits in soy boom areas redirected them to other regions where they had branches. This increase in bank lending was concentrated outside of soy-producing regions and in the manufacturing and service sectors. Note that this finding stands in contrast to the findings on the effect of agricultural technical change on structural transformation through the labor supply channel, which operates in local labor markets with limited migration responses (see Table A.5). Instead, the capital supply channel operates across regions financially integrated with soy boom areas through the bank branch network. 
We can simultaneously estimate the effect of the labor and capital supply mechanisms on structural transformation by adding to our baseline specification, described in equation (1), a measure of exposure to capital inflows from soy boom areas through the bank branch network following Bustos et al. (2020). In this analysis, we use the change in employment share in manufacturing between 2000 and 2010 as our measure of structural transformation. Estimation results are reported in Appendix Table A.9. Two key findings emerge. First, we confirm that the local effect of soy technical change is concentrated in soy-producing regions, and in low-R\&D intensive manufacturing - what we label $L$ industries in this paper. On the other hand, the indirect effect of soy technical change via bank exposure to soy boom areas has the following characteristics: it affects manufacturing in destination regions, it is concentrated in non-soy producing regions, and it is stronger for high-R\&D intensive manufacturing - what we label $H$ industries in this paper.

These results have relevant implications for the role of technical change in agriculture for industrialization and growth. In particular, they suggest that while agricultural savings can foster the growth of productivity-enhancing manufacturing in urban regions financially integrated via the bank network, the reallocation of former agricultural workers towards low-skill intensive industries can slow down productivity growth at the local level. Thus, our findings indicate that structural transformation obtained through unskilled laborsaving technical change in agriculture - which may be quite common when developing countries adopt agricultural technologies from more developed ones - can attenuate the standard gains from reallocation into manufacturing emphasized by the existing literature, and potentially accentuate regional productivity inequalities.

\subsection{Robustness Tests}

In this section, we address some additional concerns regarding the interpretation of our estimates. First, we investigate whether the expansion of $L$ manufacturing industries in areas experiencing technical change in soy could be the result of larger local demand for agricultural inputs or larger local supply of agricultural outputs for further processing. In this case, the expansion of manufacturing employment would be driven by sectors connected to soy production via input-output linkages. This includes sectors using soy as an input - such as the food processing industry - or that produce inputs for the soy sector - such as the production of fertilizers, herbicides or other agricultural inputs. To identify the sectors linked to soy production via input-output linkages we use the Input-Output tables computed by the IBGE. ${ }^{37}$ Although the majority of the output of the soy sector is exported, two downstream manufacturing sectors report using soy as an input: "Slaughtering and preparation of meat and fish" (SNA code 1091) and "Other food

\footnotetext{
${ }^{37}$ The tables are publicly available on the IBGE website: https://www.ibge.gov.br/en/statistics/economic/nationalaccounts/. This IO Tables use the SNA sector classification, which include 67 sectors.
} 
products" (SNA code 1093). ${ }^{38}$ Upstream industries of the soy sector include: "Fertilizers and other inorganic chemicals" (2412, 2413, 2419) and "Refined petroleum" (232).

In Table A.10 in the Appendix we replicate the main results of the paper excluding upstream and downstream industries. As shown, the estimated coefficients that we obtain are similar in magnitude to those obtained in the main tables of the paper. For example, the coefficient capturing the effect of soy technical change on employment in the $L$ manufacturing industry has a magnitude of 0.121 in Table 5 , and a magnitude of 0.124 when excluding sectors connected via input-output linkages in Table A.10. We interpret these results as indicating that the effect of soy technical change on local employment is not driven by local demand effects in manufacturing industries related to soy via production networks.

Next, we investigate to what extent the reduction in innovation within high $R \& D$ industries has the potential to reduce productivity not only in this industry but also in the local low R\&D industry through local knowledge spillovers. Note that this is key for our empirical identification strategy that compares microregions differently affected by soy technical change, and thus requires that knowledge spillovers are stronger within than across regions. Evidence from the existing literature suggests that spillovers exist and tend to be local, as shown, for example, in Greenstone, Hornbeck, and Moretti (2010) and Giroud, Lenzu, Maingi, and Mueller (2021) in the context of the US. Greenstone et al. (2010) document that the construction of large manufacturing plants in a given county generates productivity spillovers for existing plants in the same county. Importantly, they show that such spillovers occur across manufacturing industries, and are stronger across industries with larger technological linkages, as measured by industry-to-industry R\&D flows and industry-to-industry patent citations (Ellison, Glaeser, and Kerr, 2010). Building on the same experiment, Giroud et al. (2021) show that across firms and acrossindustry spillovers are very local, and only travel across regions within multi-plant firms.

Still, it is worth exploring whether spillovers are also local in our context. First, we turn to survey evidence from PINTEC. This survey indicates, for each firm acquiring innovation externally, the location of the external firm that developed the innovation. In particular, the survey asks respondents to indicate the Brazilian state in which the external innovating firm is located. Survey responses show that around $70 \%$ of external innovation is developed by firms located in the same state as the respondent, consistent with important local innovation spillovers. Second, we directly test for spillovers across microregions, our unit of observation. We augment our main specification of the effect of

\footnotetext{
${ }^{38}$ These 2 SNA sectors correspond to the following sectors in the CNAE 1.0 sector classification at 4-digits used in the paper: (1511)-(1514), (1521)-(1523), (1531)-(1533), (1541)-(1543), (1571), (1572), (1551)-(1556), (1559), (1581)-(1586), and (1589). To identify which of these 29 CNAE 1.0 sectors use soy as an input we looked at the description of the activities classified in each sector according documentation provided by the National Commission of Classifications (CONCLA). We identified 5 sectors whose description indicate they use soy as an input: 1531, 1532, 1533, 1586, 1589. We also added to the downstream industries the biofuels sector.
} 
soy technical change on local manufacturing productivity with three additional controls capturing changes in soy technical change in neighboring microregions. More specifically, we include soy technical change in the five closest, in the five to ten closest, and in the ten to twenty closest microregions. Each group captures geographical spillovers at different distances, starting from adjacent microregions. Table A.11 reports the results for our key measures of manufacturing productivity. As shown, we find that changes in agricultural productivity in nearby microregions do not affect local manufacturing productivity.

\section{Conclusions}

The reallocation of labor from agriculture into manufacturing is generally regarded as positive in the economic development literature. Several studies have documented that the manufacturing sector has, on average, higher productivity and pays higher wages. However, little is known about which type of workers are released from the agricultural sector and which manufacturing industries absorb them during the process of structural transformation. Our paper contributes to the literature by showing that the forces driving structural transformation can shape the type of industries in which a country specializes. In particular, we show that when labor reallocation from agriculture to manufacturing is driven by agricultural productivity growth that displaces unskilled labor, it can generate an expansion in less innovation-intensive manufacturing sectors, which can reduce investment in innovation and slow down aggregate manufacturing productivity growth. 


\section{References}

Acemoglu, D. (2002, October). Directed Technical Change. The Review of Economic Studies 69(4), 781-809.

Acemoglu, D., U. Akcigit, H. Alp, N. Bloom, and W. Kerr (2018, November). Innovation, reallocation, and growth. American Economic Review 108(11), 3450-91.

Acemoglu, D. and V. Guerrieri (2008, June). Capital Deepening and Nonbalanced Economic Growth. Journal of Political Economy 116(3), 467-498.

Autor, D., D. Dorn, G. H. Hanson, G. Pisano, and P. Shu (2020, September). Foreign competition and domestic innovation: Evidence from us patents. American Economic Review: Insights 2(3), 357-74.

Baumol, W. (1967). Macroeconomics of Unbalanced Growth: The Anatomy of Urban Crisis. American Economic Review 57(3), 415-26.

Berg, J. (2010). Laws or luck? understanding rising formality in brazil in the 2000s.

Boppart, T. (2014). Structural Change and the Kaldor Facts in a Growth Model with Relative Price Effects and Non-Gorman Preferences. Econometrica.

Bragança, A. (2014). Three Essays on Rural Development in Brazil. Ph. D. thesis, PUCRio.

Buera, F., J. Kaboski, R. Rogerson, and J. Vizcaino (2021). Skill-Biased Structural Change. Review of Economic Studies.

Bustos, P., B. Caprettini, and J. Ponticelli (2016). Agricultural Productivity and Structural Transformation: Evidence from Brazil. American Economic Review.

Bustos, P., G. Garber, and J. Ponticelli (2020). Capital accumulation and structural transformation. The Quarterly Journal of Economics 135(2), 1037-1094.

Carlino, G. and W. R. Kerr (2015). Agglomeration and innovation. In Handbook of regional and urban economics, Volume 5, pp. 349-404. Elsevier.

Caselli, F. (2005). Chapter 9 Accounting for Cross-Country Income Differences. Volume 1, Part A of Handbook of Economic Growth, pp. 679 - 741. Elsevier.

Caselli, F. and W. J. Coleman (2001, June). The U.S. Structural Transformation and Regional Convergence: A Reinterpretation. Journal of Political Economy 109(3), 584616.

Cohen, W. M. and S. Klepper (1992). The anatomy of industry r\&d intensity distributions. The American Economic Review 82(4), 773-799.

Cohen, W. M., R. C. Levin, and D. C. Mowery (1987). Firm size and r\& d intensity: A re-examination. The Journal of Industrial Economics 35(4), 543-565.

Cohen, W. M., R. R. Nelson, and J. P. Walsh (2000). Protecting their intellectual assets: Appropriability conditions and why us manufacturing firms patent (or not). 
Costa, F., J. Garred, and J. P. Pessoa (2016, September). Winners and losers from a commodities-for-manufactures trade boom. Journal of International Economics 102, $50-69$.

Dix-Carneiro, R. and B. K. Kovak (2019, March). Margins of labor market adjustment to trade. Journal of International Economics 117, 125-142.

Duffy, M. and D. Smith (2001). "Estimated Costs of Crop Production in Iowa". Iowa State University Extension Service FM1712.

Ellison, G., E. L. Glaeser, and W. R. Kerr (2010). What causes industry agglomeration? evidence from coagglomeration patterns. American Economic Review 100(3), 11951213.

Fernandez-Cornejo, J., C. Klotz-Ingram, and S. Jans (2002). "Estimating Farm-Level Effects of Adopting Herbicide-Tolerant Soybeans in the USA". Journal of Agricultural and Applied Economics 34, 149-163.

Ferreira, F., S. Firpo, and J. Messina (2017). Ageing Poorly? Accounting for the Decline in Earnings Inequality in Brazil, 1995-2012. IDB Working Paper Series.

Foster, A. D. and M. R. Rosenzweig (1996). Technical Change and Human-Capital Returns and Investments: Evidence from the Green Revolution. The American Economic Review 86(4), 931-953.

Franck, R. and O. Galor (2019). Flowers of evil? industrialization and long run development. Journal of Monetary Economics.

Giroud, X., S. Lenzu, Q. Maingi, and H. Mueller (2021). Propagation and amplification of local productivity spillovers. Technical report, National Bureau of Economic Research.

Gollin, D., D. Lagakos, and M. E. Waugh (2014). The Agricultural Productivity Gap. Quarterly Journal of Economics.

Gollin, D., S. Parente, and R. Rogerson (2002). The Role of Agriculture in Development. American Economic Review, 160-64.

Greenstone, M., R. Hornbeck, and E. Moretti (2010). Identifying agglomeration spillovers: Evidence from winners and losers of large plant openings. Journal of Political Economy 118(3), 536-598.

Grossman, G. and E. Helpman (1991). Innovation and Growth in the Global Economy. The MIT Press.

Helpman, E., O. Itskhoki, M.-A. Muendler, and S. J. Redding (2017). Trade and inequality: From theory to estimation. The Review of Economic Studies 84(1), 357-405.

Herrendorf, B. and T. Schoellman (2018). Wages, Human Capital and Structural Transformation. American Economic Journal: Macroeconomics.

Huggins, D. R. and J. P. Reganold (2008). "No-Till: the Quiet Revolution". Scientific American 299, 70-77. 
IBGE (2006). "Censo Agropecuário 2006". Rio de Janeiro, Brazil: Instituto Brasileiro de Geografia e Estatística (IBGE).

Imbert, C., M. Seror, Y. Zhang, and Y. Zylberberg (2020). Migrants and firms: Evidence from china.

Jaffe, A. B. (1988). Demand and supply influences in $r$ \& d intensity and productivity growth. The Review of Economics and Statistics 70(3), 431-437.

Kongsamut, P., S. Rebelo, and D. Xie (2001). Beyond Balanced Growth. The Review of Economic Studies 68(4), 869-882.

Krugman, P. (1987). The Narrow Moving Band, the Dutch Disease, and the Competitive Consequences of Mrs. Thatcher: Notes on Trade in the Presence of Dynamic Scale Economies. Journal of Development Economics 27(1-2), 41-55.

Kuznets, S. (1973). Modern Economic Growth: Findings and Reflections. American Economic Review.

Lagakos, D. and M. E. Waugh (2013). Selection, Agriculture, and Cross-Country Productivity Differences. American Economic Review 103(2), 948-80.

Lagaras, S. (2017). Corporate takeovers and labor restructuring. Available at SSRN 3222950.

Lewis, A. W. (1954). Economic Development with Unlimited Supplies of Labor. The Manchester School.

Lucas, R. (1988). On the mechanics of economic development. Journal of Monetary Economics.

Matsuyama, K. (1992a). A Simple Model of Sectoral Adjustment. The Review of Economic Studies, 375-388.

Matsuyama, K. (1992b, December). Agricultural Productivity, Comparative Advantage, and Economic Growth. Journal of Economic Theory 58(2), 317-334.

McMillan, M. and D. Rodrik (2011). Globalization, Structural Change and Productivity Growth. In Making Globalization Socially Sustainable. ILO/WTO.

McMillan, M., D. Rodrik, and C. Sepulveda (2017). Structural Change, Fundamentals and Growth: A Framework and Case Studies. National Bureau of Economic Research Working Paper Series No. 23378.

Murphy, K. M., A. Shleifer, and R. Vishny (1989). Income Distribution, Market Size, and Industrialization. The Quarterly Journal of Economics 104(3), 537-564.

Ngai, L. R. and C. A. Pissarides (2007). Structural change in a multisector model of growth. American Economic Review 97(1), 429-443.

Nurkse, R. (1953). Problems of Capital Formation in Underdeveloped Countries. Oxford: Basil Blackwell. 
Pakes, A. and M. Schankerman (1984). An Exploration into the Determinants of Research Intensity, pp. 209-232. University of Chicago Press.

Peters, M. (2019). Market size and spatial growth - evidence from germany's post-war population expulsions. Unpublished manuscript.

Restuccia, D., D. T. Yang, and X. Zhu (2008). Agriculture and Aggregate Productivity: A Quantitative Cross-Country Analysis. Journal of Monetary Economics 55(2), 234 250.

Romer, P. (1990). Endogenous Technological Change. Journal of Political Economy 98(5).

Rostow, W. (1960). The Stages of Economic Growth: A Non Communist Manifesto. Cambridge University Press.

Rybczynski, T. (1955). Factor endowments and relative commodity prices. Economica.

Schultz, T. (1953). The Economic Organization of Agriculture. New York: McGraw-Hill.

USDA (2001). "Agriculture in Brazil and Argentina: Developments and Prospects for Major Field Crops". United States Department of Agriculture, Economic Research Service.

USDA (2012). "Agricultural Biotechnology Annual". United States Department of Agriculture, Economic Research Service. 


\section{$5 \quad$ Figures and Tables}

\section{Figure 1: Soy Production and Employment}

(a) Soy: Area planted

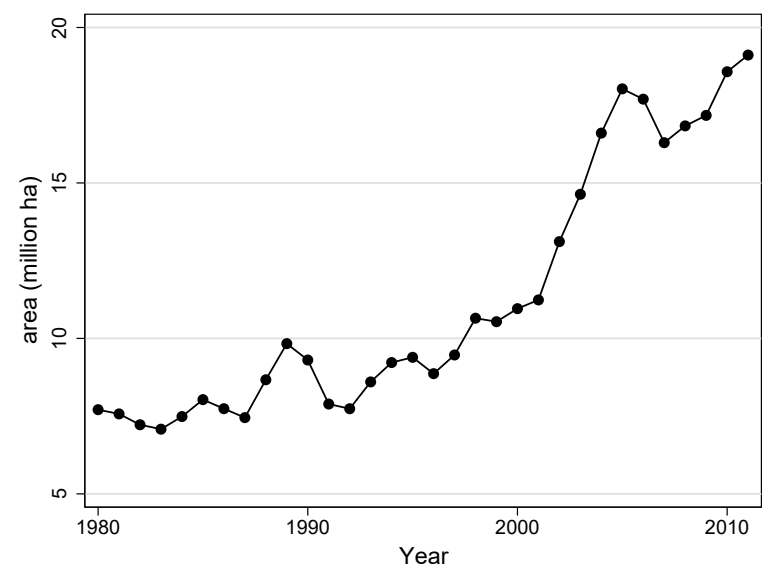

(c) Soy: Employment by Skill Group

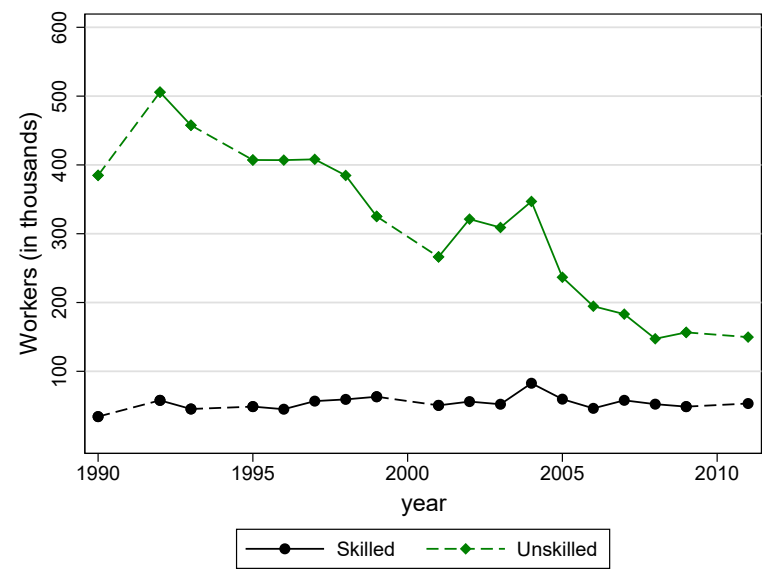

(b) Soy: Employment

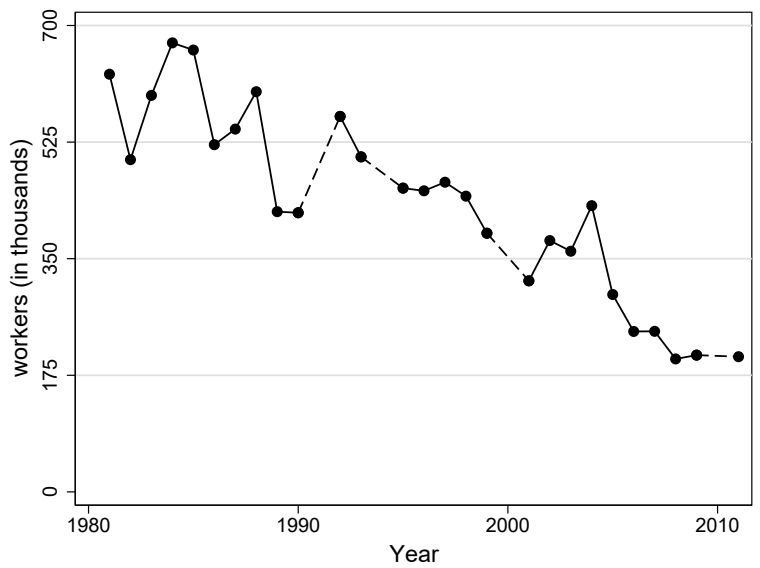

(d) Share of Skilled Workers by Agricultural Activity

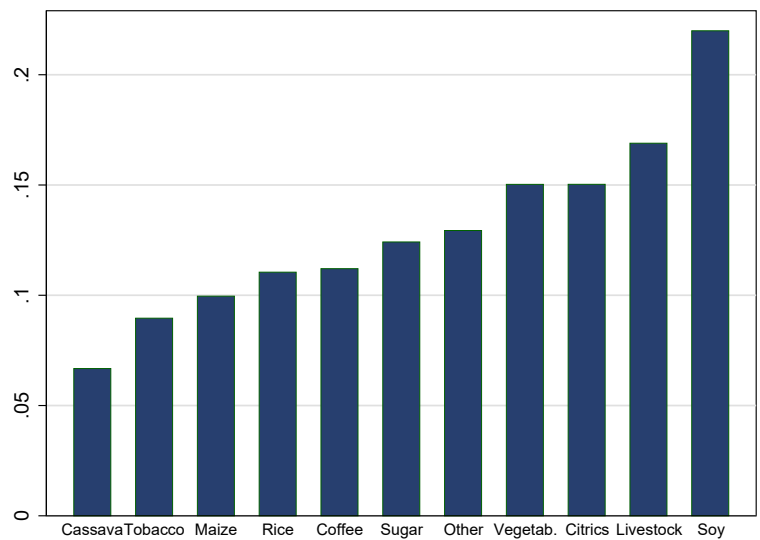

Notes: Figures in Panels (a) and (b) are from Bustos et al. (2016). Data sources are CONAB (Panel A), PNAD (Panel B and C) and 2000 Population Census (Panel D). CONAB is the Companhia Nacional de Abastecimento, an agency within the Brazilian Ministry of Agriculture, which runs surveys of farmers and agronomists to monitor the annual harvests of major crops in Brazil. PNAD is the Brazilian National Household Sample Survey. The states of Rondonia, Acre, Amazonas, Roraima, Pará, Amapá, Tocantins, Mato Grosso do Sul, Goias, and Distrito Federal are excluded due to incomplete coverage by PNAD in the early years of the sample. In Panels $\mathrm{C}$ and $\mathrm{D}$, an individual is classified as skilled if she has completed at least the $8^{t h}$ grade. 
Figure 2: $\Delta$ in Potential Soy Yield 2000-2010

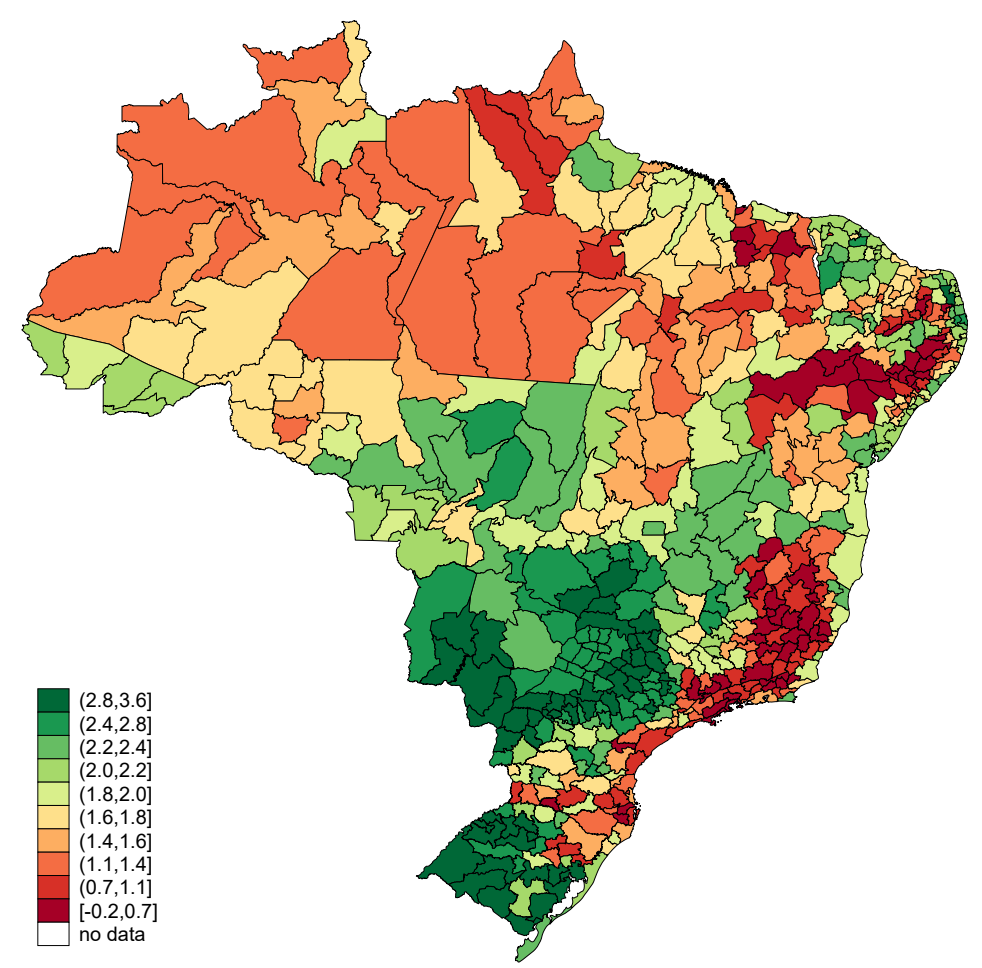

Notes: Authors' calculations from FAO-GAEZ data. Technical change in soy production for each microregion is computed by deducting the average potential yield under low inputs from the average potential yield under high inputs. 


\section{Figure 3: Effect of agricultural technical change on manufacturing employment \\ Yearly Social Security Data (1998-2009)}

(a) Unskilled Labor

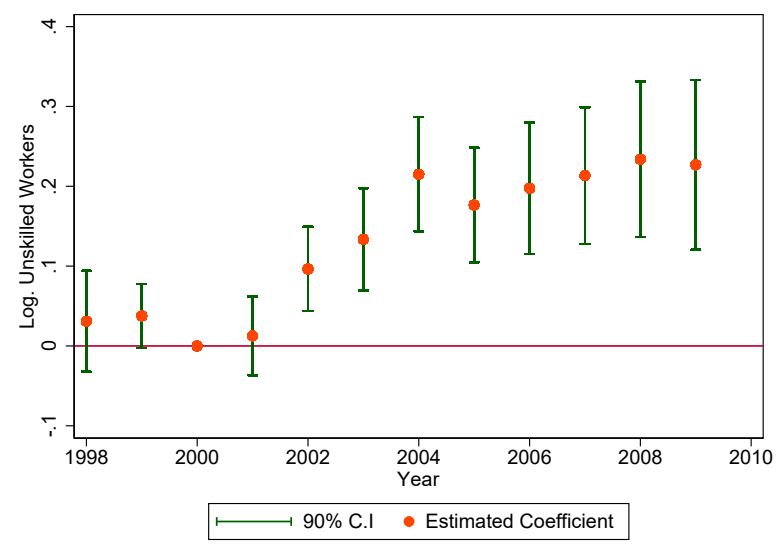

(b) Skilled Labor

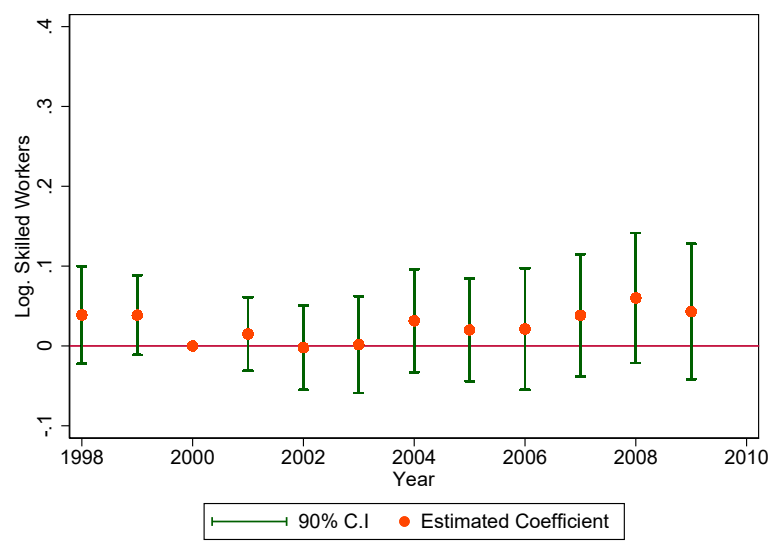

Notes: The figure shows the point estimates and the $90 \%$ confidence intervals for the estimates of the $\beta_{j}$ of equation (2) where $\ln y_{k, r, t}$ corresponds to aggregate log employment of unskilled and skilled labor in microregion $k$ located in region $r$ at the end of year $t$ in manufacturing. An individual is classified as skilled if she has completed at least the $8^{t h}$ grade. (Source: RAIS). Standard errors are clustered at the microregion level. 


\section{Figure 4: Effect of agricultural technical change on labor and capital allocation within manufacturing \\ Yearly Social Security Data (1998-2009) and Annual Manufacturing Survey(2000-2009)}

\section{Labor}

(a) L Industry

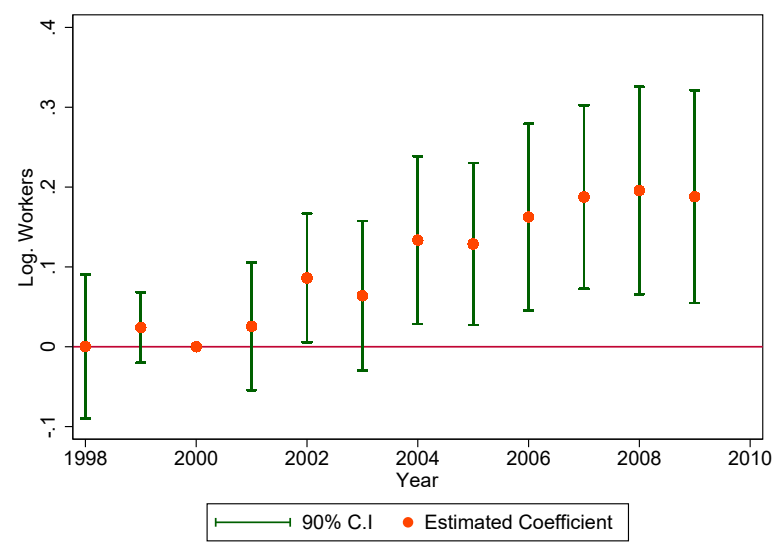

(b) H Industry

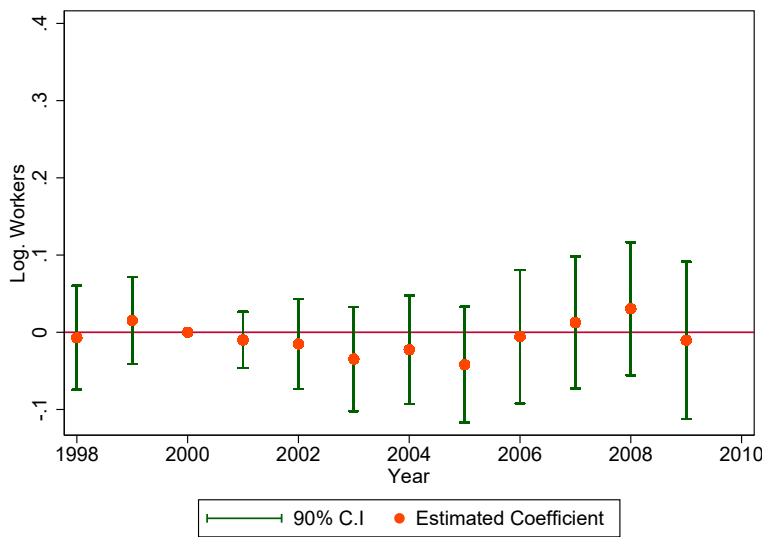

\section{Physical Capital}

(c) L Industry

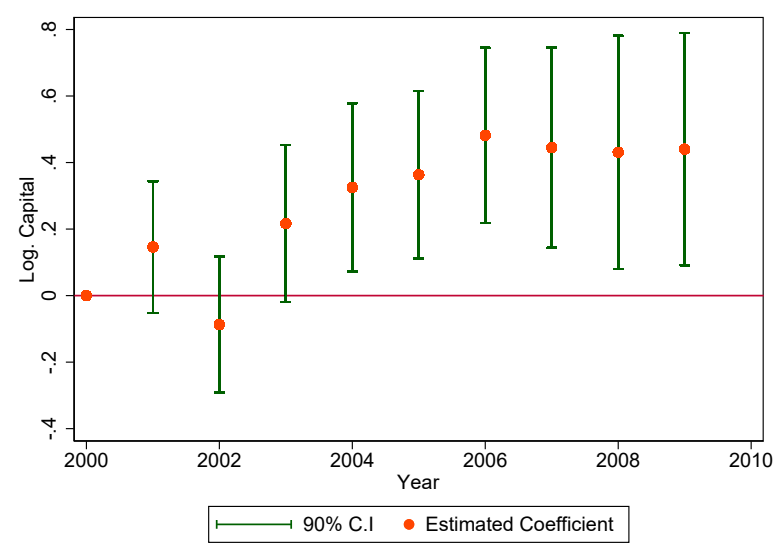

(d) $\mathbf{H}$ Industry

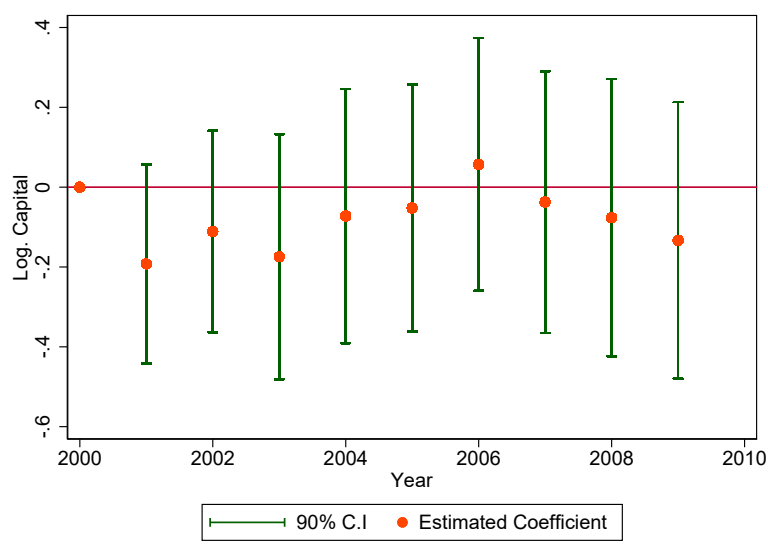

Notes: The figure shows the point estimates and the $90 \%$ confidence intervals for the estimates of the $\beta_{j}$ coefficients of equation (2) where $\ln y_{k, r, t}$ corresponds to aggregate log employment and log capital in microregion $k$ located in region $r$ at the end of year $t$ for each type of manufacturing industry (Source: PIA and RAIS). Manufacturing industries are classified as $\mathrm{L}$ or $\mathrm{H}$ depending on whether their R\&D intensity is below or above the median in 2000 (weighting industries by number of employees so that each group captures around 50 percent of total manufacturing employment). We define $\mathrm{R} \& \mathrm{D}$ intensity as $\mathrm{R} \& \mathrm{D}$ expenditure as a share of total sales at baseline and we source it from from the 2000 Pesquisa de Inovação Tecnológica (PINTEC). Standard errors are clustered at the microregion level. 
Figure 5: The effect of agricultural technical change on manufacturing productivity

(a) Value Added per Worker

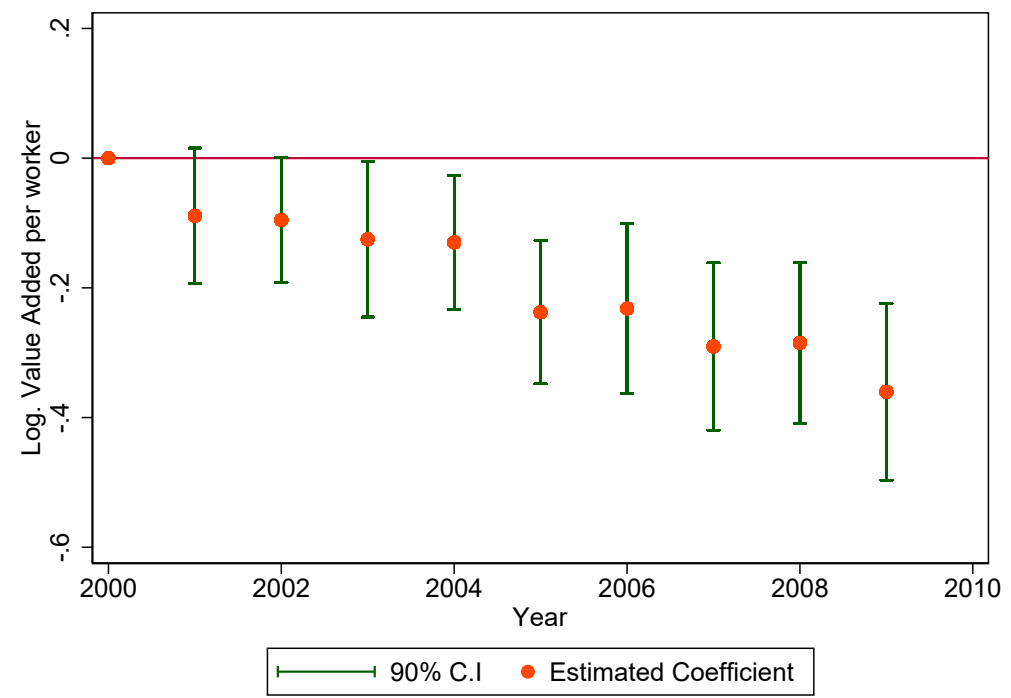

(c) Value Added per Worker: decomposition

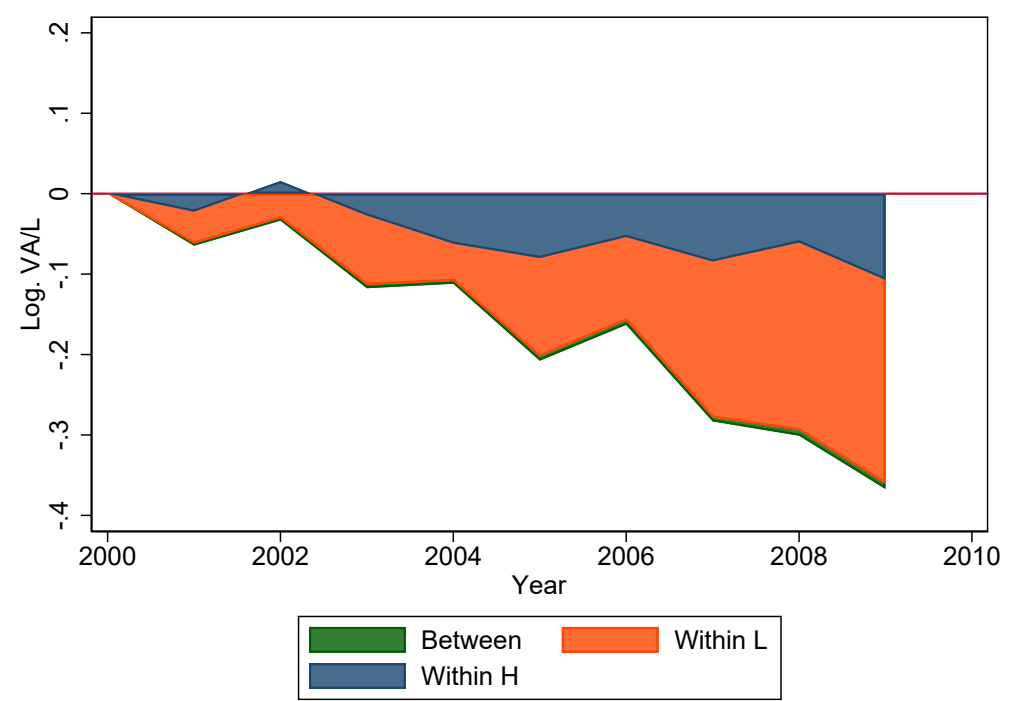

(b) Total Factor Productivity

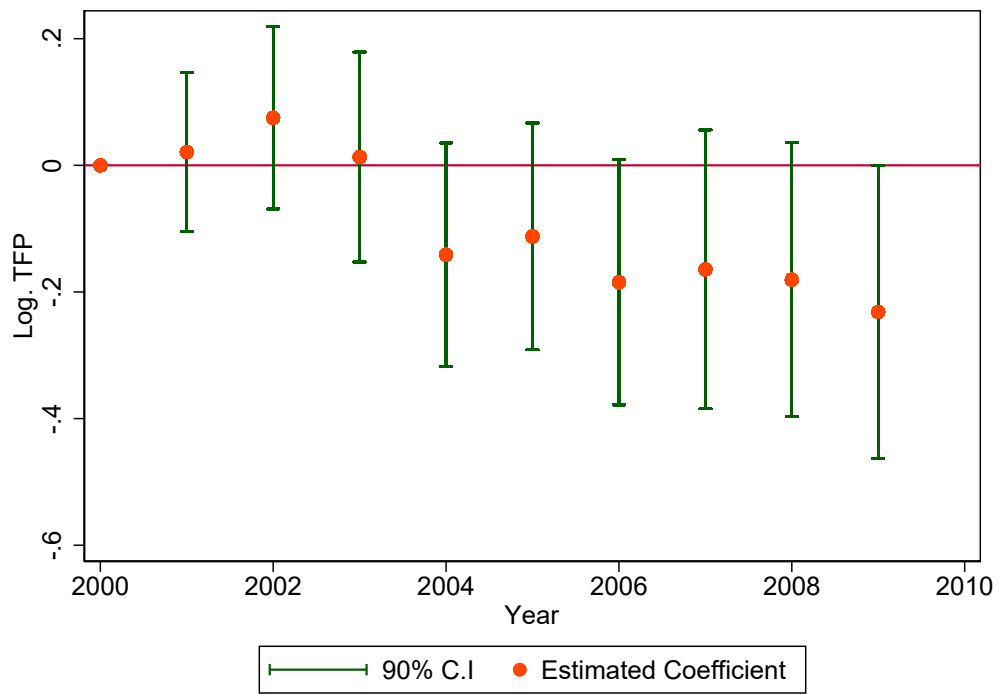

(d) Total Factor Productivity: decomposition

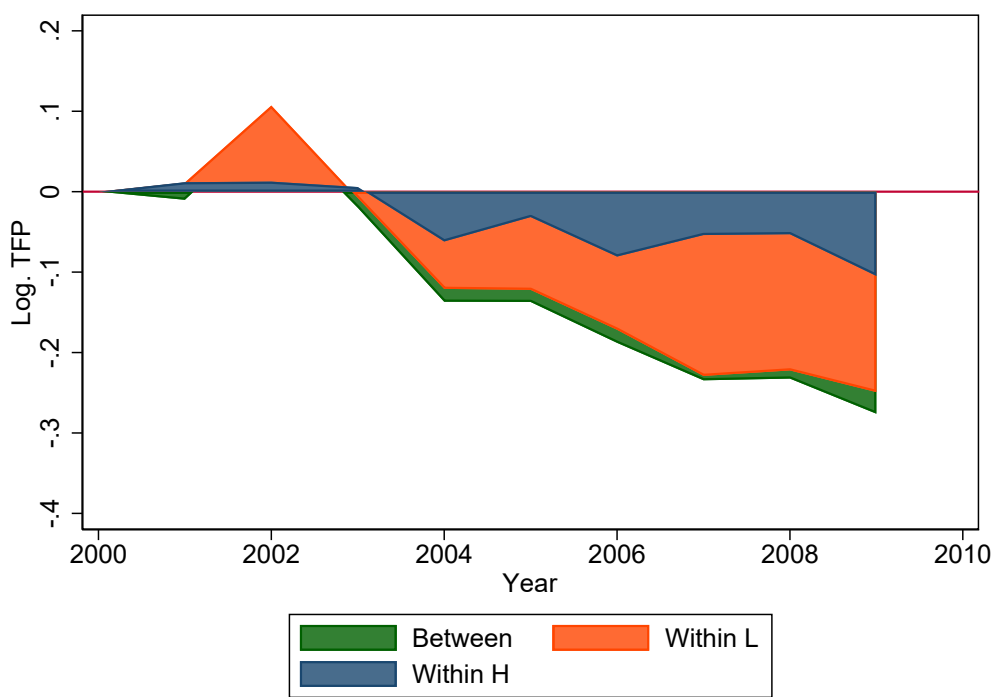

Notes: Graphs (a) and (b) show the point estimates and $90 \%$ confidence intervals for the estimates of the $\beta_{j}$ coefficients of equation (2) using two measures of manufacturing productivity as outcomes: $\log$ value added per worker and log TFP (Source: PIA). Graphs (c) and (d) show the decomposition of the total effect into the within components for each of the two industries and the between component across industries. Standard errors are clustered at the microregion level. 


\section{Figure 6: Effect of agricultural technical change on expenditure on non-innovative and innovative occupations \\ Yearly Social Security Data (1998-2009)}

Non-innovative labor wage bill

(a) L Industry

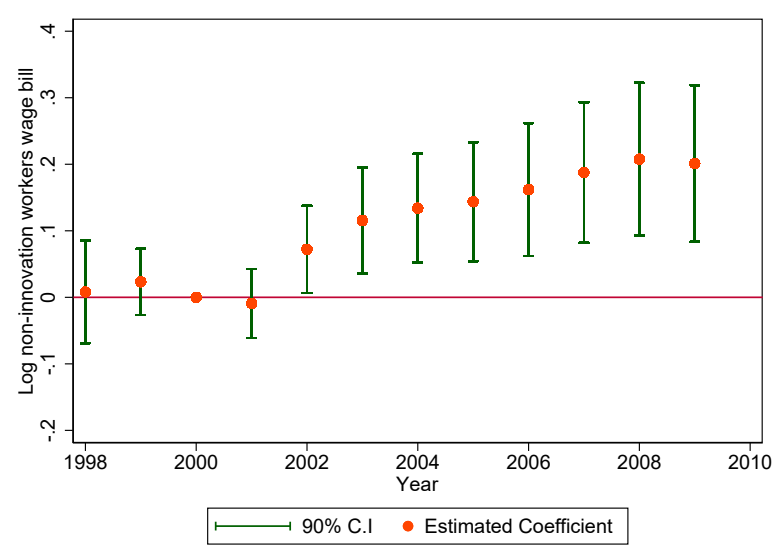

(b) H Industry

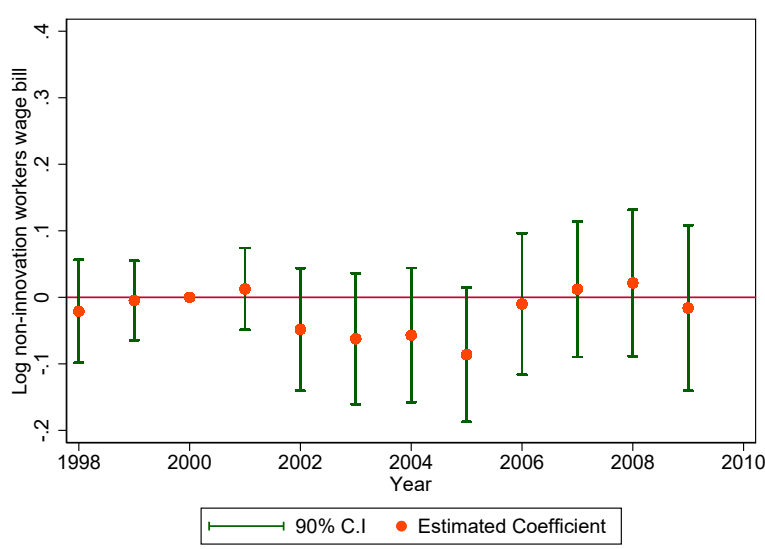

Innovative labor wage bill

(c) L Industry

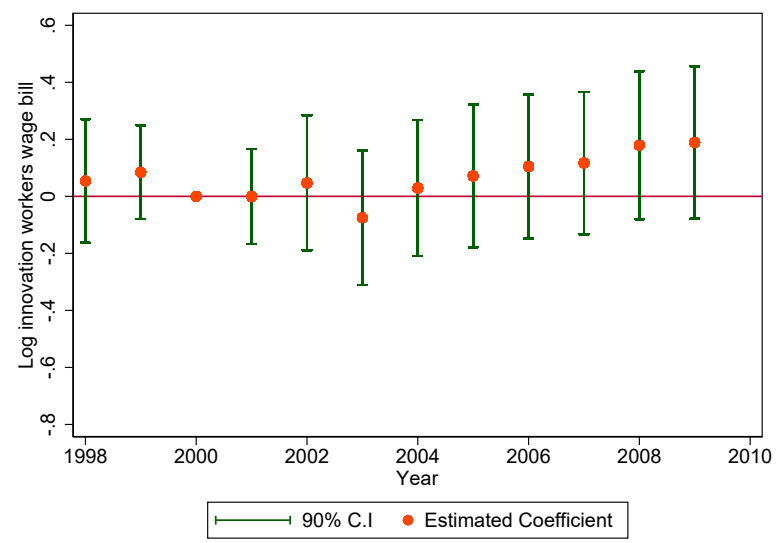

(d) H Industry

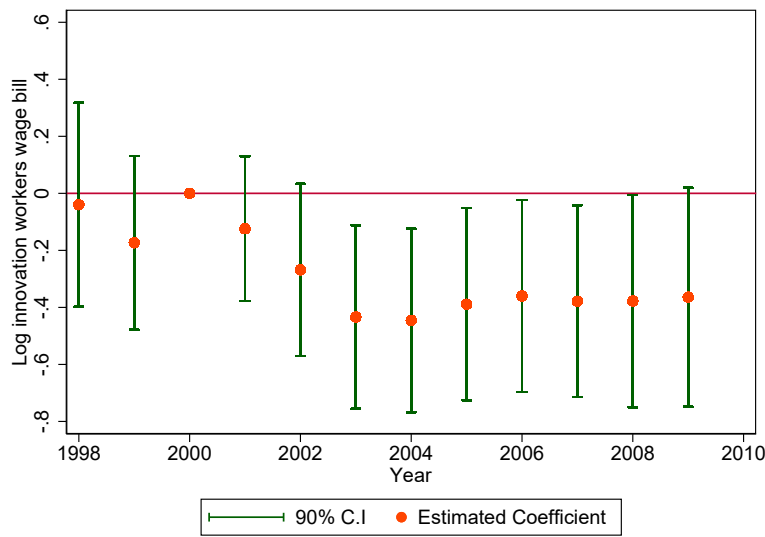

Notes: The figure shows the point estimates and the $90 \%$ confidence intervals for the estimates of the $\beta_{j}$ coefficients of equation (2) where $\ln y_{k, t}$ corresponds to the log wage bill of non-innovative and innovative labor in microregion $k$ located in region $r$ at the end of year $t$ for $\mathrm{L}$ and $\mathrm{H}$ manufacturing industries (Source: RAIS). An occupation is classified as innovative following the methodology outlined in Section 2.4. Manufacturing industries are classified as L or H depending on whether their R\&D intensity is below or above the median in 2000 (weighting industries by number of employees so that each group captures around 50 percent of total manufacturing employment). We define R\&D intensity as R\&D expenditure as a share of total sales at baseline and we source it from from the 2000 Pesquisa de Inovação Tecnológica (PINTEC). Standard errors are clustered at the microregion level. 
Figure 7: Decomposition of effect of agricultural technical change on innovation activities in the $H$ industry

Yearly Social Security Data (1998-2009)

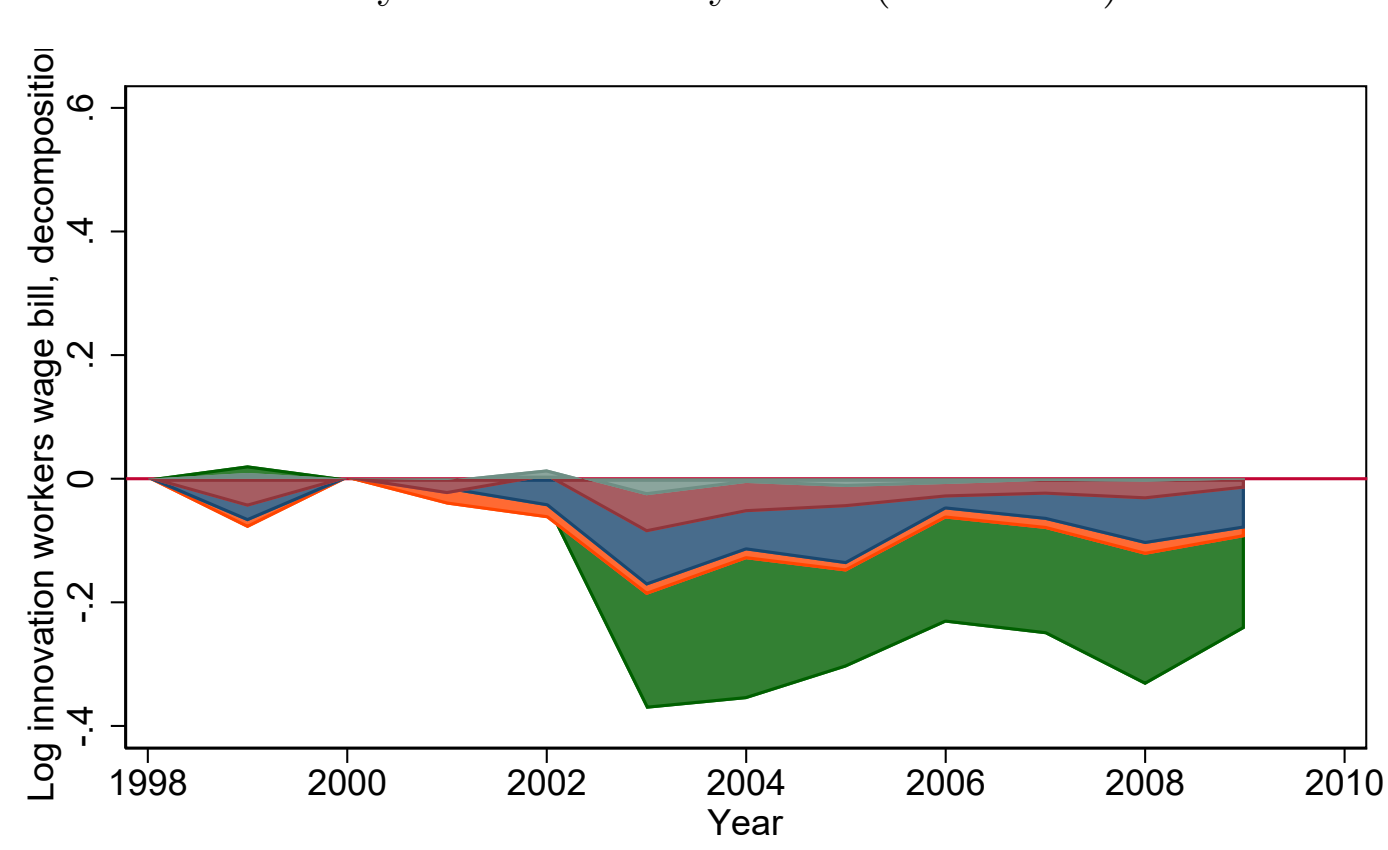

Stayers

Informal/Self-Employed

Entrants

L Industry

Notes: The graph shows the decomposition of the total effect of agricultural technical change on log wage bill of innovative workers in the H manufacturing industry into components coming from workers who stay in the industry, workers transitioning from either informality or self employment, workers transitioning from the L industry, workers who are entering the labor force, and works we the median in 2000 (weighting industries by number of employees so that each group captures around 50 percent of total manufacturing employment). We define R\&D intensity as R\&D
expenditure as a share of total sales at baseline and we source it from from the 2000 Pesquisa de Inovação Tecnológica (PINTEC). Standard errors are clustered at the microregion level. 


\section{Figure 8: Agricultural technical change and the reallocation of innovation activities across industries and occupations}

(a) Reallocation of innovative workers' wage bill from $H$ to $L$

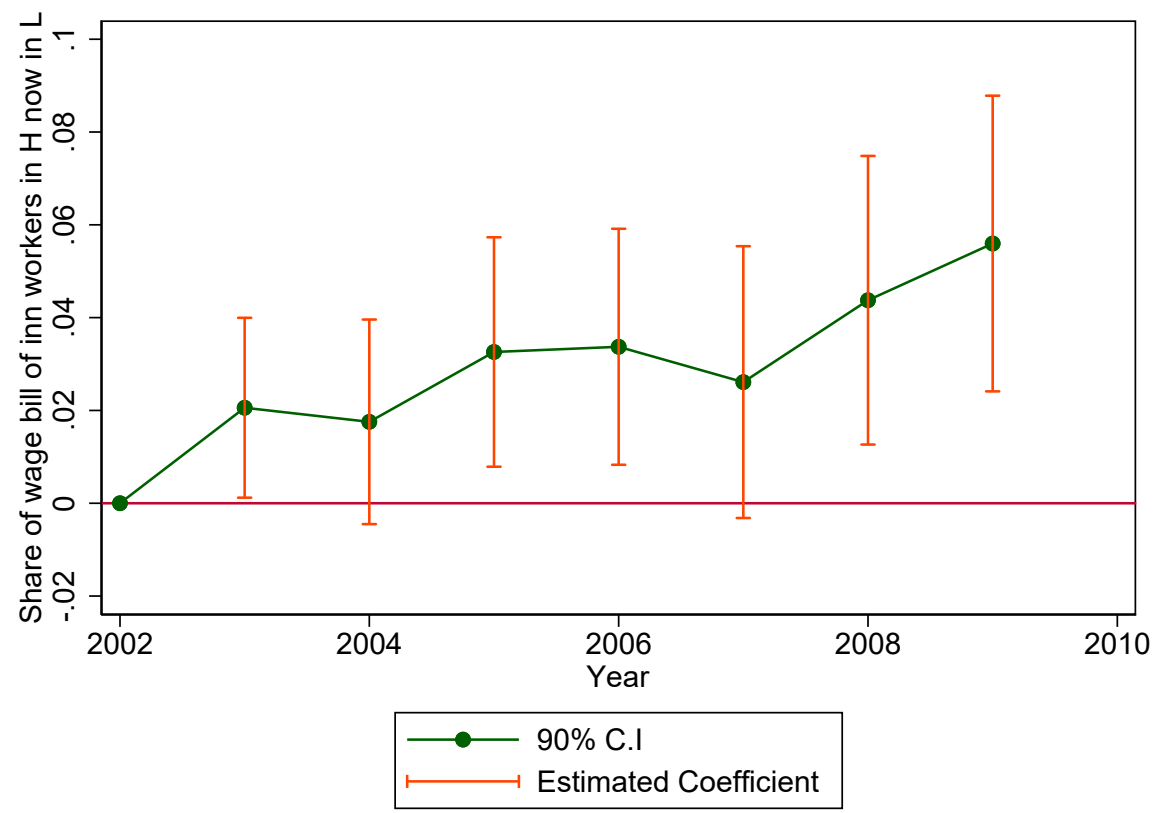

(b) Decomposition by new occupation in the $L$ industry

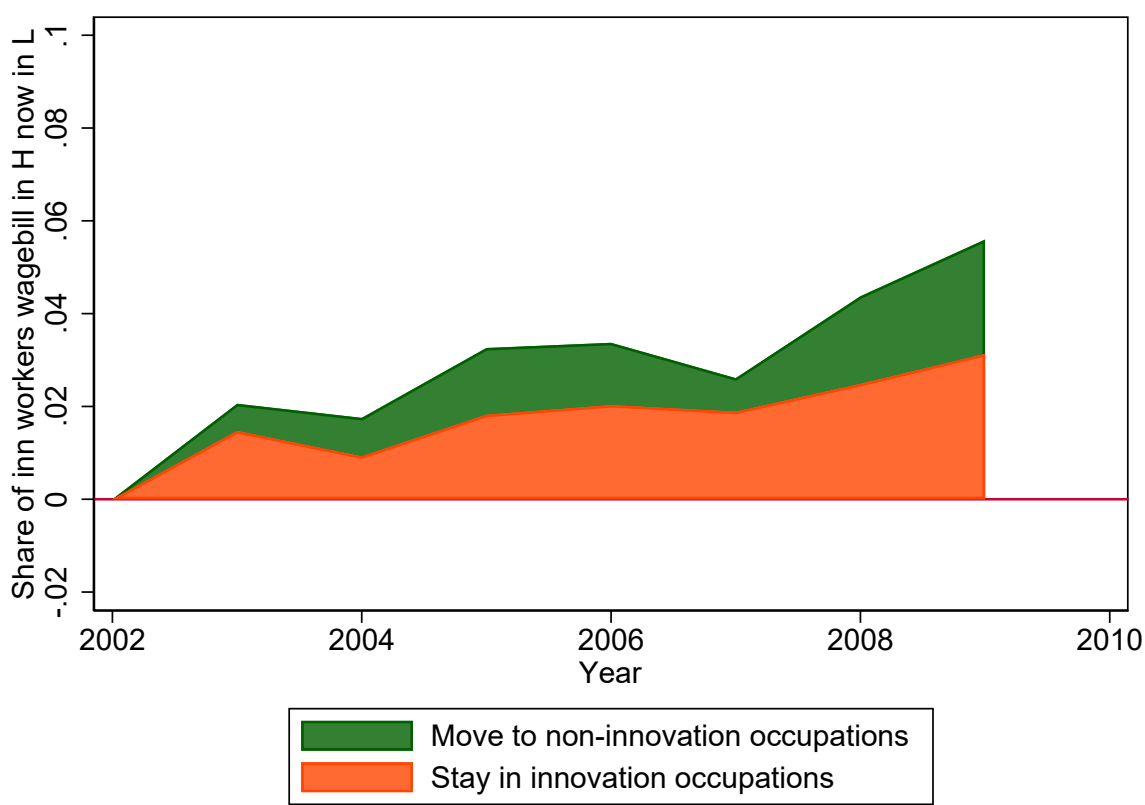

Notes: Graph (a) shows the point estimates and the $90 \%$ confidence intervals for the estimates of the $\beta_{j}$ coefficients of equation (2) where the outcome variable is the share of the wage bill of workers who were employed in innovative occupations in the $\mathrm{H}$ sector during a year between 1998 and 2002 that moved to the L industry in microregion $k$ located in region $r$ at the end of year $t$ (Source: RAIS). Graph (b) decomposes Graph (a) by the new occupation in the L industry of workers who were employed in innovative occupations in the H sector during a year between 1998 and 2002. An occupation is classified as innovative following the methodology outlined in Section 2.4. Manufacturing industries are classified as L or $\mathrm{H}$ depending on whether their R\&D intensity is below or above the median in 2000 (weighting industries by number of employees so that each group captures around 50 percent of total manufacturing employment). We define $R \& D$ intensity as $R \& D$ expenditure as a share of total sales at baseline and we source it from from the 2000 Pesquisa de Inovação Tecnológica (PINTEC). Standard errors are clustered at the microregion level. 
Table 1: Summary Statistics of the Sample of Individuals by Sector

\begin{tabular}{|c|c|c|}
\hline & 2000 & 2010 \\
\hline \multicolumn{3}{|l|}{ Agriculture } \\
\hline Age & 38.0 & 39.0 \\
\hline Male (\% of the Total) & 89.3 & 81.2 \\
\hline White (\% of the Total) & 55.4 & 48.6 \\
\hline \multicolumn{3}{|l|}{ Education level (highest degree obtained) } \\
\hline Less than Middle School (\% of the Total) & 86.1 & 72.7 \\
\hline Completed Middle School (\% of the Total) & 7.4 & 13.8 \\
\hline High School Graduates ( $\%$ of the Total) & 5.2 & 11.4 \\
\hline University Graduates (\% of the Total) & 1.3 & 2.1 \\
\hline Average log real hourly wage & 0.81 & 1.06 \\
\hline For skilled labor & 1.39 & 1.38 \\
\hline For unskilled labor & 0.71 & 0.95 \\
\hline \multicolumn{3}{|l|}{ Manufacturing L Industry } \\
\hline Age & 36.8 & 37.3 \\
\hline Male (\% of the Total) & 61.6 & 58.7 \\
\hline White (\% of the Total) & 65.0 & 55.6 \\
\hline \multicolumn{3}{|l|}{ Education level (highest degree obtained) } \\
\hline Less than Middle School (\% of the Total) & 52.2 & 36.8 \\
\hline Completed Middle School (\% of the Total) & 20.4 & 21.5 \\
\hline High School Graduates (\% of the Total) & 21.9 & 35.2 \\
\hline University Graduates (\% of the Total) & 5.5 & 6.6 \\
\hline Average log real hourly wage & 1.23 & 1.51 \\
\hline For skilled labor & 1.73 & 1.63 \\
\hline For unskilled labor & 1.15 & 1.23 \\
\hline \multicolumn{3}{|l|}{ Manufacturing $\mathrm{H}$ Industry } \\
\hline Age & 36.28 & 36.9 \\
\hline Male (\% of the Total) & 80.6 & 76.2 \\
\hline White (\% of the Total) & 63.0 & 55.2 \\
\hline \multicolumn{3}{|l|}{ Education level (highest degree obtained) } \\
\hline Less than Middle School (\% of the Total) & 49.8 & 31.3 \\
\hline Completed Middle School (\% of the Total) & 20.0 & 19.8 \\
\hline High School Graduates (\% of the Total) & 23.4 & 39.8 \\
\hline University Graduates (\% of the Total) & 6.8 & 9.1 \\
\hline Average log real hourly wage & 1.58 & 1.66 \\
\hline For skilled labor & 1.92 & 1.81 \\
\hline For unskilled labor & 1.24 & 1.35 \\
\hline \multicolumn{3}{|l|}{ Services } \\
\hline Age & 37.1 & 37.8 \\
\hline Male (\% of the Total) & 67.3 & 62.1 \\
\hline White (\% of the Total) & 58.9 & 50.8 \\
\hline \multicolumn{3}{|l|}{ Education level (highest degree obtained) } \\
\hline Less than Middle School (\% of the Total) & 51.1 & 36.0 \\
\hline Completed Middle School ( $\%$ of the Total) & 17.9 & 19.3 \\
\hline High School Graduates ( $\%$ of the Total) & 23.4 & 34.3 \\
\hline University Graduates (\% of the Total) & 7.6 & 10.4 \\
\hline Average log real hourly wage & 1.42 & 1.51 \\
\hline For skilled labor & 1.77 & 1.67 \\
\hline For unskilled labor & 1.01 & 1.24 \\
\hline
\end{tabular}

Notes: The data comes from the Population Censuses for years 2000 and 2010. Summary statistics refer to our final sample of individuals as detailed in Section 2.3. An individual is classified as skilled if she has at least completed the $8^{t h}$ grade. This level should be attained when an individual is 14 or 15 years old and is equivalent to graduating from middle school. Manufacturing industries are classified as $\mathrm{L}$ or $\mathrm{H}$ intensive depending on whether their R\&D intensity is below or above the median in 2000 (weighting industries by number of employees so that each group captures around 50 percent of total manufacturing employment). We define R\&D intensity as $R \& D$ expenditure as a share of total sales at baseline and we source it from from the 2000 Pesquisa de Inovação Tecnológica (PINTEC). 
Table 2: Summary Statistics of the Sample of Microregions

\begin{tabular}{|c|c|c|c|c|c|c|}
\hline & \multicolumn{6}{|c|}{ Panel A: Decadal Variables } \\
\hline & \multirow[b]{2}{*}{ Source: } & \multicolumn{2}{|c|}{2000} & \multicolumn{3}{|c|}{$\Delta 2000-2010$} \\
\hline & & Mean & $\mathrm{SD}$ & Mean & SD & Observations \\
\hline Potential Yields & $F A O-G A E Z$ & & & & & \\
\hline Soy & & 0.286 & 0.135 & 1.787 & 0.740 & 557 \\
\hline Maize & & 1.847 & 0.9984 & 3.082 & 1.639 & 557 \\
\hline Employment Shares & Population Census & & & & & \\
\hline Agriculture & & 0.279 & 0.140 & -0.050 & 0.055 & 557 \\
\hline Manufacturing L Industry & & 0.081 & 0.055 & 0.007 & 0.033 & 557 \\
\hline Manufacturing $\mathbf{H}$ Industry & & 0.067 & 0.043 & -0.001 & 0.025 & 557 \\
\hline Services & & 0.573 & 0.118 & 0.044 & 0.057 & 557 \\
\hline Log. Employment & Population Census & & & & & \\
\hline Agriculture & & 8.268 & 0.890 & 0.122 & 0.249 & 557 \\
\hline Manufacturing L Industry & & 7.076 & 1.569 & 0.358 & 0.400 & 557 \\
\hline Manufacturing H Industry & & 6.897 & 1.485 & 0.309 & 0.394 & 557 \\
\hline Services & & 9.194 & 1.887 & 0.404 & 0.175 & 557 \\
\hline
\end{tabular}

\begin{tabular}{llccc}
\hline & & Panel B: Yearly Variables & \\
\hline & Source: & Mean & SD & Observations \\
\hline
\end{tabular}

Manufacturing Employment Log. Employment

Manufacturing L Industry

Manufacturing $\mathbf{H}$ Industry

Log. Non-Innovative Wage Bill

Manufacturing L Industry

Manufacturing $\mathbf{H}$ Industry

Log. Innovative Wage Bill

Manufacturing L Industry

Manufacturing $\mathbf{H}$ Industry
RAIS (1998-2009)

$\begin{array}{lll}7.753 & 1.315 & 3,816 \\ 7.509 & 1.384 & 3,816 \\ & & \\ & & \\ 16.103 & 2.206 & 3,816 \\ 15.883 & 2.304 & 3,816 \\ & & \\ & & \\ 12.781 & 2.869 & 3,816 \\ 12.523 & 3.273 & 3,816\end{array}$

Manufacturing Productivity Log. Value Added per Worker Manufacturing L Industry Manufacturing $\mathbf{H}$ Industry

Log. Value Added per Wage Bill Manufacturing L Industry Manufacturing $\mathbf{H}$ Industry

Log. Total Factor Productivity Manufacturing L Industry Manufacturing $\mathbf{H}$ Industry
PIA (2000-2009)

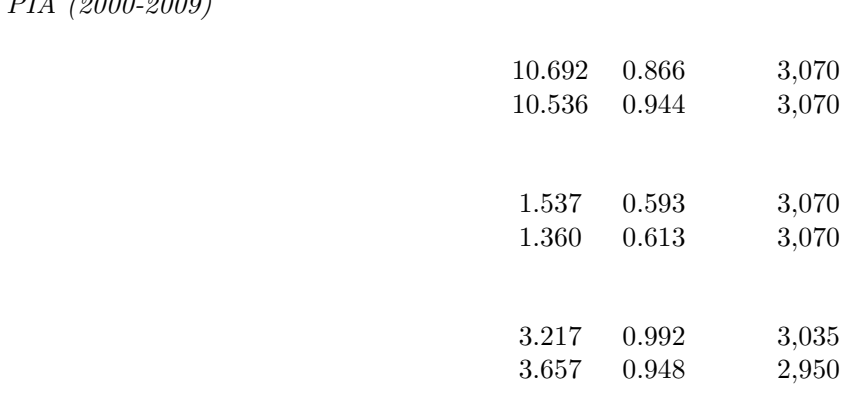

PIA (2000-2009)

$\begin{array}{lll}17.812 & 2.216 & 3,037 \\ 16.359 & 2.580 & 2,971\end{array}$

Log. Capital

Manufacturing L Industry Manufacturing $\mathbf{H}$ Industry

Notes: The data sources are the Population Census $(2000,2010)$, RAIS and PIA. Manufacturing industries are classified as Low-R\&D or High-R\&D intensive depending on whether their R\&D intensity is below or above the median in 2000 (weighting industries by number of employees so that each group captures around 50 percent of total manufacturing employment). We define R\&D intensity as R\&D expenditure as a share of total sales at baseline and we source it from from the 2000 Pesquisa de Inovação Tecnológica (PINTEC). A worker is classified as skilled if she has completed at least the $8^{\text {th }}$ grade (completed middle school). 


\section{Table 3: Effect of agricultural technical change on sectoral employment shares, manufacturing growth and manufacturing productivity}

Panel A: Decadal Population Census Data (2000 and 2010)

\begin{tabular}{lccc} 
& \multicolumn{3}{c}{ Change in employment shares by sector } \\
\cline { 2 - 4 } & $\begin{array}{c}\text { Agriculture } \\
(1)\end{array}$ & $\begin{array}{c}\text { Manufacturing } \\
(2)\end{array}$ & $\begin{array}{c}\text { Services } \\
(3)\end{array}$ \\
\hline & $-0.033^{* * *}$ & & $0.008^{*}$ \\
$\Delta A_{\text {soy }}$ & {$[0.005]$} & {$[0.005]$} & {$[0.004]$} \\
& & & 557 \\
Observations & 557 & 557 & 0.359 \\
R-squared & 0.246 & 0.166 & Yes \\
Region FE & Yes & Yes & Yes \\
Controls & Yes & Yes &
\end{tabular}

Panel B: Yearly Manufacturing Survey Data (2000-2009)

\begin{tabular}{|c|c|c|c|c|c|}
\hline \multirow[t]{2}{*}{ Outcome: } & \multicolumn{5}{|c|}{ Manufacturing Outcomes } \\
\hline & $\begin{array}{c}\text { Labor } \\
(1)\end{array}$ & $\begin{array}{c}\text { Capital } \\
(2)\end{array}$ & $\begin{array}{c}\mathrm{VA} / \mathrm{L} \\
(3) \\
\end{array}$ & $\begin{array}{c}\mathrm{VA} / \mathrm{WL} \\
(4)\end{array}$ & $\begin{array}{c}\text { TFP } \\
(5)\end{array}$ \\
\hline$A_{\text {soy }}$ & $\begin{array}{c}0.095^{* * *} \\
{[0.035]}\end{array}$ & $\begin{array}{c}0.257^{* *} \\
{[0.092]}\end{array}$ & $\begin{array}{c}-0.141^{* * *} \\
{[0.043]}\end{array}$ & $\begin{array}{c}-0.133^{* * *} \\
{[0.040]}\end{array}$ & $\begin{array}{c}-0.197^{* *} \\
{[0.080]}\end{array}$ \\
\hline Observations & 3,070 & 3,069 & 3,070 & 3,070 & 3,069 \\
\hline R-squared & 0.977 & 0.913 & 0.876 & 0.735 & 0.544 \\
\hline Microregion FE & Yes & Yes & Yes & Yes & Yes \\
\hline Year FE & Yes & Yes & Yes & Yes & Yes \\
\hline Controls $\times$ Linear trends & Yes & Yes & Yes & Yes & Yes \\
\hline Region x Year FEs & Yes & Yes & Yes & Yes & Yes \\
\hline
\end{tabular}

Notes: Panel A shows coefficient estimates corresponding to equation (1). Changes in dependent variables are calculated over the years 2000 and 2010. The unit of observation is the microregion. These regressions include as controls the share of rural population, income per capita (in logs), population density (in logs), literacy rate, all observed in the 1991 Population Census, a measure of technical change in maize and region fixed effects. Panel B shows coefficient estimates corresponding to equation (3). The dependent variables correspond to the total labor (in logs), total capital (in logs), total value added divided by employment (in logs), total value added divided by total wage bill (in logs) and total factor productivity for manufacturing in each microregion. We include only those microregions that have positive employment for all the years in the sample. Controls include the share of rural population, income per capita (in logs), population density (in logs), literacy rate, all observed in 1991, all interacted with a linear trend, a measure of technical change in maize and region times year fixed effects. Robust standard errors are reported in brackets in Panel A, and standard errors clustered at the microregion level are reported in brackets in Panel B. Significance levels: ${ }^{* * *} p<0.01,{ }^{* *} p<0.05,{ }^{*} p<0.1$. 


\section{Table 4: Effect of agricultural technical change on sectoral employment shares by skill group \\ Decadal Population Census Data (2000 and 2010)}

\begin{tabular}{|c|c|c|c|c|c|c|}
\hline \multirow{2}{*}{$\begin{array}{l}\text { Outcome: } \\
\text { Sector: }\end{array}$} & \multicolumn{3}{|c|}{$\begin{array}{c}\text { Change in employment shares of } \\
\text { unskilled workers by sector }\end{array}$} & \multicolumn{3}{|c|}{$\begin{array}{l}\text { Change in employment shares of } \\
\text { skilled workers by sector }\end{array}$} \\
\hline & $\begin{array}{l}\text { Agriculture } \\
(1)\end{array}$ & $\begin{array}{l}\text { Manufacturing } \\
(2)\end{array}$ & $\begin{array}{l}\text { Services } \\
\quad(3)\end{array}$ & $\begin{array}{l}\text { Agriculture } \\
\quad(4)\end{array}$ & $\begin{array}{l}\text { Manufacturing } \\
(5)\end{array}$ & $\begin{array}{l}\text { Services } \\
\quad(6)\end{array}$ \\
\hline$\Delta A_{\text {soy }}$ & $\begin{array}{c}-0.033^{* * *} \\
{[0.006]}\end{array}$ & $\begin{array}{c}0.030 * * * \\
{[0.005]}\end{array}$ & $\begin{array}{c}0.004 \\
{[0.004]}\end{array}$ & $\begin{array}{c}-0.015^{* * *} \\
{[0.004]}\end{array}$ & $\begin{array}{c}0.014^{* * *} \\
{[0.005]}\end{array}$ & $\begin{array}{c}0.001 \\
{[0.005]}\end{array}$ \\
\hline Observations & 557 & 557 & 557 & 557 & 557 & 557 \\
\hline R-squared & 0.126 & 0.157 & 0.208 & 0.047 & 0.112 & 0.103 \\
\hline Region FE & Yes & Yes & Yes & Yes & Yes & Yes \\
\hline Controls & Yes & Yes & Yes & Yes & Yes & Yes \\
\hline
\end{tabular}

Notes: Changes in dependent variables are calculated over the years 2000 and 2010 (source: Population Censuses). The unit of observation is the microregion. All the regressions include as controls the share of rural population, income per capita (in logs), population density (in logs), literacy rate, all observed in the 1991 Population Census, a measure of technical change in maize and region fixed effects. Robust standard errors reported in brackets. Significance levels: ${ }^{* * *} p<0.01,{ }^{* *} p<0.05,{ }^{*} p<0.1$. 


\section{Table 5: Effect of agricultural technical change on industrial specialization within manufacturing}

\begin{tabular}{lcc} 
Panel A: Decadal Population Census Data $(2000$ and 2010$)$ & \\
\hline Outcome: & Change in employment by manufacturing industry \\
\cline { 2 - 3 } Industry: & $\begin{array}{c}\text { L Industry } \\
(1)\end{array}$ & $\begin{array}{c}\text { H Industry } \\
(2)\end{array}$ \\
\hline \multirow{2}{*}{$\begin{array}{l}\text { soy } \\
\text { Observations }\end{array}$} & $0.233^{* * *}$ & 0.015 \\
R-squared & {$[0.038]$} & {$[0.036]$} \\
Region FE & 557 & 557 \\
Controls & 0.129 & 0.099 \\
\hline
\end{tabular}

Panel B: Yearly Social Security Data (1998-2009)

\begin{tabular}{lcc}
\hline \multirow{2}{*}{$\begin{array}{l}\text { Outcome: } \\
\text { Industry: }\end{array}$} & \multicolumn{2}{c}{ Employment by manufacturing industry } \\
\cline { 2 - 3 } & $\begin{array}{c}\text { L Industry } \\
(1)\end{array}$ & $\begin{array}{c}\text { H Industry } \\
(2)\end{array}$ \\
\hline & $0.121^{* *}$ & -0.008 \\
$A_{\text {soy }}$ & {$[0.050]$} & {$[0.037]$} \\
& & \\
Observations & 5,640 & 5,640 \\
R-squared & 0.455 & 0.410 \\
Microregion FE & Yes & Yes \\
Year FE & Yes & Yes \\
Controls $\times$ Linear trends & Yes & Yes \\
Region $x$ Year FEs & Yes & Yes \\
\hline
\end{tabular}

Panel C: Yearly Manufacturing Survey Data (2000-2009)

\begin{tabular}{lcc} 
Outcome: & \multicolumn{2}{c}{ Capital by manufacturing industry } \\
\cline { 2 - 3 } Industry: & $\begin{array}{c}\text { L Industry } \\
\text { (1) }\end{array}$ & $\begin{array}{c}\text { H Industry } \\
(2)\end{array}$ \\
\hline & $0.360^{* * *}$ & 0.027 \\
$A_{\text {soy }}$ & {$[0.112]$} & {$[0.115]$} \\
& & \\
Observations & 3,037 & 2,969 \\
R-squared & 0.891 & 0.894 \\
Microregion FE & Yes & Yes \\
Year FE & Yes & Yes \\
Controls $\times$ Linear trends & Yes & Yes \\
Region $x$ Year FEs & Yes & Yes \\
\hline
\end{tabular}

Notes: In Panel A the dependent variables are changes in total employment (in logs) calculated over the years 2000 and 2010 (source: Population Censuses). The unit of observation is the microregion. Controls include: share of rural population in 1991, income per capita (in logs), population density (in logs), and literacy rate, all observed in the 1991 Population Census, as well as a measure of technical change in maize and region fixed effects. In Panel B, the dependent variable is total employment (in logs) for each manufacturing industry in each microregion. We use aggregate information from RAIS at the microregion-industry level for the time period 1998-2009. We include only those microregions that have positive employment for all the years in the sample. In Panel C, the dependent variable is capital (in logs) for each manufacturing industry in each microregion. We use aggregate information from PIA at the microregion level for the time period 2000-2009. In Panels B and C, $A_{\text {soy }}$ is defined as potential soy yield under high inputs for the years between 2003 and 2009, and the potential soy yield under low inputs for the years between 2000 and 2002. Controls include the share of rural population, income per capita (in logs), population density (in logs), literacy rate, all observed in 1991, all interacted with a linear trend, a measure of technical change in maize and region year fixed effects. In these regressions, manufacturing industries are classified as L or $\mathrm{H}$ depending on whether their R\&D intensity is below or above the median in 2000 (weighting industries by number of employees so that each group captures around 50 percent of total manufacturing employment). We define R\&D intensity as R\&D expenditure as a share of total sales at baseline and we source it from from the 2000 Pesquisa de Inovação Tecnológica (PINTEC). Robust standard errors are reported in Panel A, and standard errors clustered at the microregion level are reported in Panels B and C. Significance levels: ${ }^{* * *} p<0.01,{ }^{* *} p<0.05,{ }^{*} p<0.1$. 


\section{Table 6: Effect of agricultural technical change on manufacturing productivity \\ Yearly Manufacturing Survey Data (2000-2009)}

\begin{tabular}{|c|c|c|c|c|c|c|}
\hline \multirow{2}{*}{$\begin{array}{l}\text { Outcomes: } \\
\text { Measure: }\end{array}$} & \multicolumn{3}{|c|}{ L Industry Productivity } & \multicolumn{3}{|c|}{ H Industry Productivity } \\
\hline & $\begin{array}{l}\text { Log Value Added } \\
\text { per Worker } \\
(1)\end{array}$ & $\begin{array}{l}\text { Log Value Added } \\
\text { per Wage Bill } \\
(2)\end{array}$ & $\begin{array}{c}\text { Log TFP } \\
\quad(3)\end{array}$ & $\begin{array}{l}\text { Log Value Added } \\
\text { per Worker } \\
(4)\end{array}$ & $\begin{array}{l}\text { Log Value Added } \\
\text { per Wage Bill } \\
(5)\end{array}$ & $\begin{array}{c}\text { Log TFP } \\
\quad(6)\end{array}$ \\
\hline$A_{\text {soy }}$ & $\begin{array}{c}-0.151^{* *} \\
{[0.059]}\end{array}$ & $\begin{array}{c}-0.135^{* *} \\
{[0.054]}\end{array}$ & $\begin{array}{c}-0.307^{* * *} \\
{[0.096]}\end{array}$ & $\begin{array}{c}-0.119^{*} \\
{[0.071]}\end{array}$ & $\begin{array}{l}-0.109^{*} \\
{[0.057]}\end{array}$ & $\begin{array}{c}-0.150^{*} \\
{[0.087]}\end{array}$ \\
\hline Observations & 3,070 & 3,070 & 3,035 & 3,070 & 3,070 & 2,949 \\
\hline R-squared & 0.796 & 0.627 & 0.605 & 0.799 & 0.635 & 0.574 \\
\hline Region x Year FEs & Yes & Yes & Yes & Yes & Yes & Yes \\
\hline Controls & Yes & Yes & Yes & Yes & Yes & Yes \\
\hline \multicolumn{7}{|c|}{$\begin{array}{l}\text { Notes: The dependent variables are: total value added divided by employment (in logs), total value added divided by total wage bill (in logs) and total } \\
\text { factor productivity for each type of manufacturing industry in each microregion as a proxy for productivity. We include only those microregions that } \\
\text { have positive employment for all the years in the sample. } A_{\text {soy }} \text { is defined as potential soy yield under high inputs for the years between } 2003 \text { and } 2009 \text {, } \\
\text { and the potential soy yield under low inputs for the years between } 2000 \text { and } 2002 \text {. Controls include the share of rural population, income per capita } \\
\text { (in logs), population density (in logs), literacy rate, all observed in } 1991 \text {, all interacted with a linear trend, a measure of technical change in maize and } \\
\text { region year fixed effects. The unit of observation is a microregion. In these regressions, manufacturing industries are classified as L or H depending on } \\
\text { whether their R\&D intensity is below or above the median in } 2000 \text { (weighting industries by number of employees so that each group captures around } 50 \\
\text { percent of total manufacturing employment). We define R\&D intensity as R\&D expenditure as a share of total sales at baseline and we source it from } \\
\text { from the } 2000 \text { Pesquisa de Inovaça } \tilde{a} \text { Tecnológica (PINTEC). Standard errors clustered at the microregion level reported in parentheses. Significance } \\
\text { levels: }{ }^{* * *} p<0.01,{ }^{* *} p<0.05,{ }^{*} p<0.1 \text {. }\end{array}$} \\
\hline
\end{tabular}




\section{Table 7: Effect of agricultural technical change on innovation in manufacturing \\ Yearly Social Security Data (1998-2009)}

\begin{tabular}{lccccc}
\hline \multirow{2}{*}{$\begin{array}{l}\text { Outcomes: } \\
\text { Industry: }\end{array}$} & \multicolumn{2}{l}{ Wage Bill of Non-Innovation Workers } & & \multicolumn{2}{c}{ Wage Bill of Innovation Workers } \\
\cline { 2 - 3 } & $\begin{array}{c}\text { L Industry } \\
(1)\end{array}$ & $\begin{array}{c}\text { H Industry } \\
(2)\end{array}$ & & $\begin{array}{c}\text { L Industry } \\
(3)\end{array}$ & $\begin{array}{c}\text { H Industry } \\
(4)\end{array}$ \\
\hline \multirow{2}{*}{$A_{\text {soy }}$} & $0.144^{* * *}$ & -0.019 & & 0.048 & $-0.274^{*}$ \\
& {$[0.047]$} & {$[0.046]$} & & {$[0.107]$} & {$[0.151]$} \\
Observations & 3,828 & 3,828 & & 3,828 & 3,828 \\
R-squared & 0.969 & 0.978 & & 0.910 & 0.905 \\
Controls & Yes & Yes & & Yes & Yes \\
\hline
\end{tabular}

Notes: The dependent variables in columns (1) and (2) are the total wage bill of non-innovation workers (in logs) for each manufacturing industry in each microregion as a proxy for industry size, and in columns (3) and (4) are the total wage bill of innovation workers (in logs) for each type of industry in every microregion as a proxy for expenditure in innovation. We use aggregate information from RAIS at the microregion-industry level for the time period 1998-2009. We include only those microregions that have positive employment for all the years in the sample. $A^{\text {soy }}$ is defined as potential soy yield under high inputs for the years between 2003 and 2009, and the potential soy yield under low inputs for the years between 1998 and 2002. Controls include the share of rural population, income per capita (in logs), population density (in logs), literacy rate, all observed in 1991, all interacted with a linear trend, a measure of technical change in maize and region year fixed effects. The unit of observation is a microregion. In these regressions, manufacturing industries are classified as Low- $R \& D$ or High- $R \& D$ intensive depending on whether their $R \& D$ intensity is below or above the median in 2000 (weighting industries by number of employees so that each group captures around 50 percent of total manufacturing employment). We define R\&D intensity as R\&D expenditure as a share of total sales at baseline and we source it from from the 2000 Pesquisa de Inovação Tecnológica (PINTEC). Standard errors clustered at the microregion level reported in parentheses. Significance levels: ${ }^{* * *} p<0.01,{ }^{* *} p<0.05,{ }^{*} p<0.1$. 


\section{A Appendix: Figures and Tables}

\section{Figure A.1: Skill Intensity and R\&D Intensity at Industry Level}

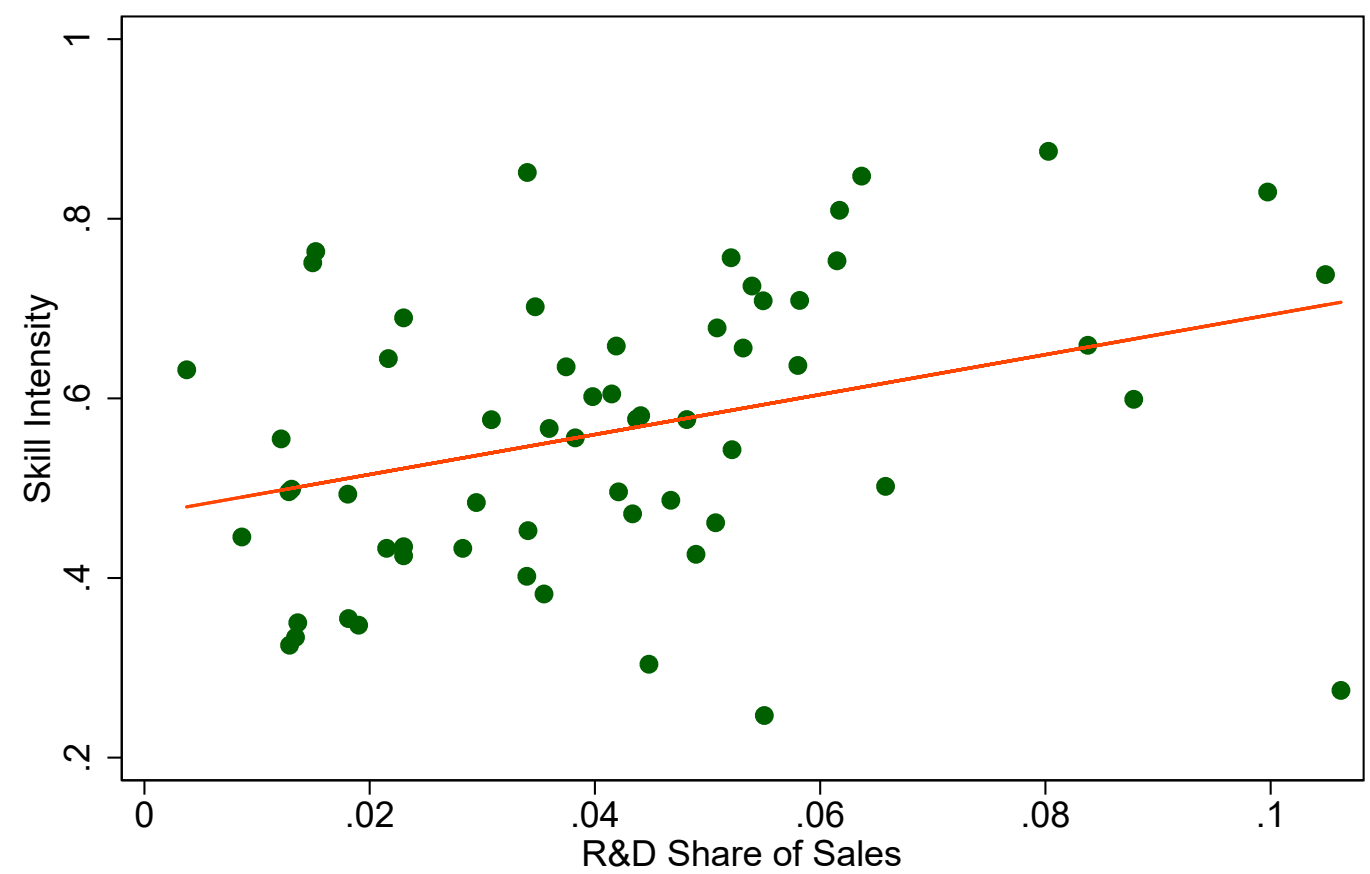

- Actual Values $\quad$ Fitted Values

Notes: We define skill intensity as the share of skilled individuals in a particular industry in Brazil at baseline and we source it from the 2000 Population Census. Our measure of R\&D activity is R\&D expenditure as a share of total sales at baseline and we source it from from the 2000 Pesquisa de Inovação Tecnológica ](PINTEC). The correlation between these variables is approximately 0.34 . 
Figure A.2: Manufacturing Employment in Innovation Intensive Occupations

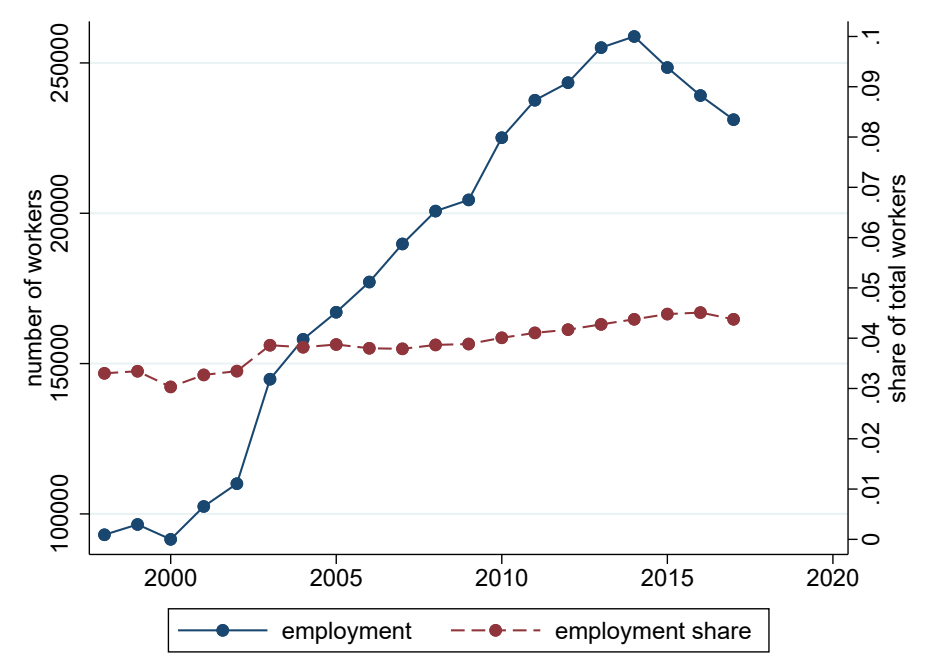

Notes: Authors' calculations using RAIS data. Innovation intensive occupations are defined using the methodology described in Section 2.4. 


\section{Figure A.3: Correlations between share of workers in innovation intensive occupations and industry-level measures of innovation}

(a) R\&D expenditure/sales

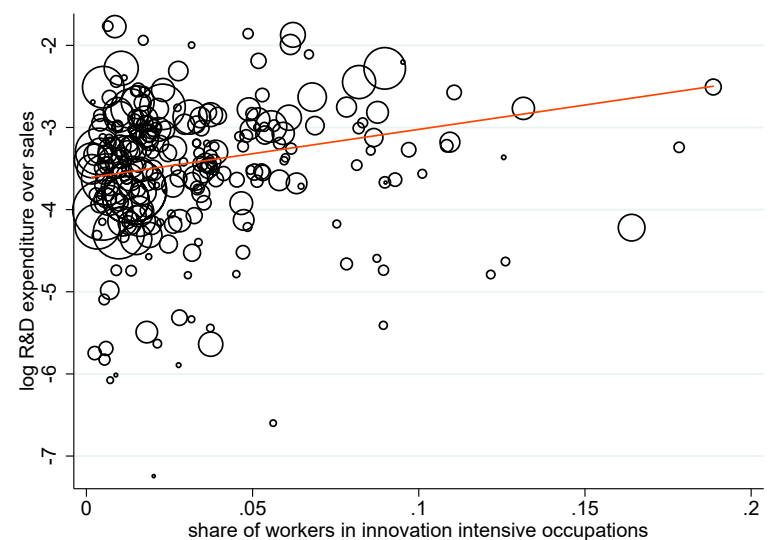

(c) Product innovation share

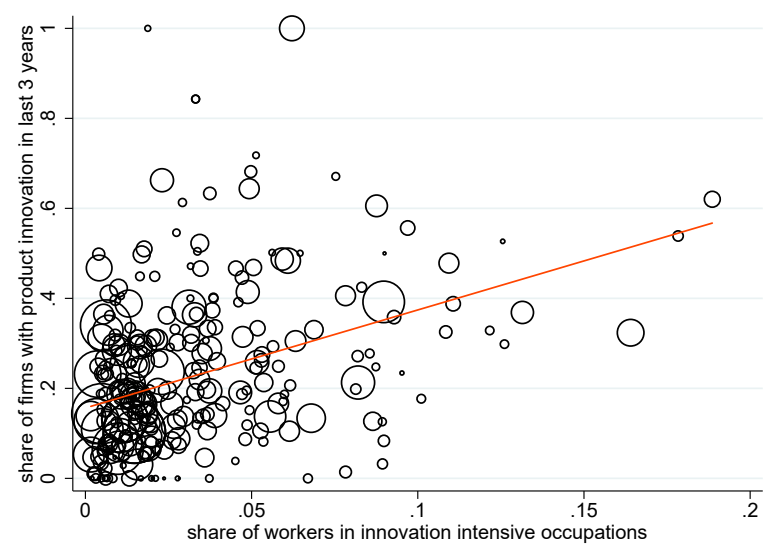

(e) Product or Process innovation share

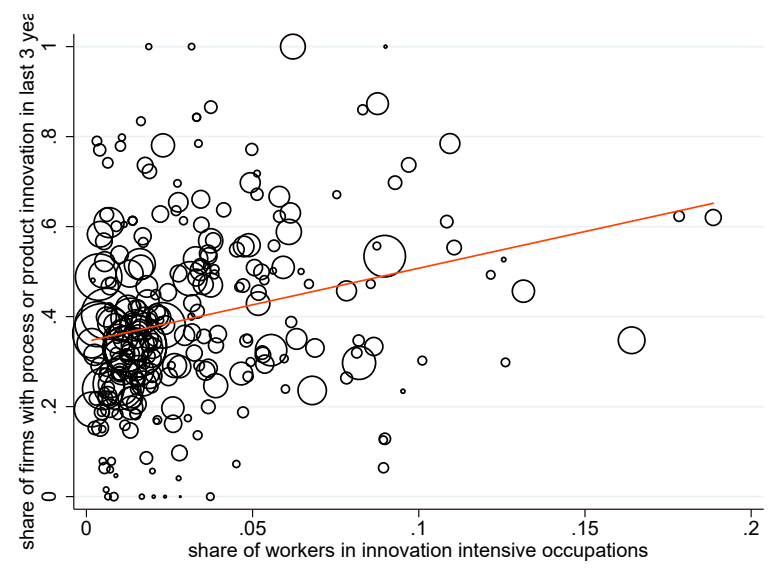

(b) Patent share

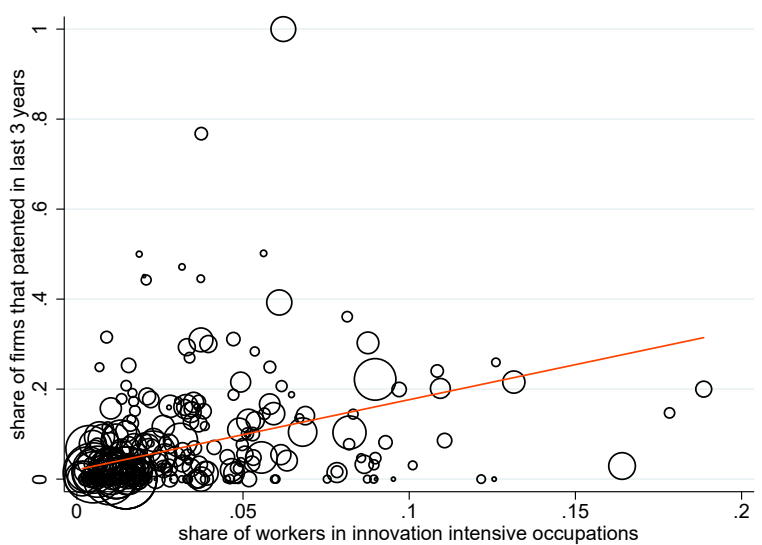

(d) Process innovation share

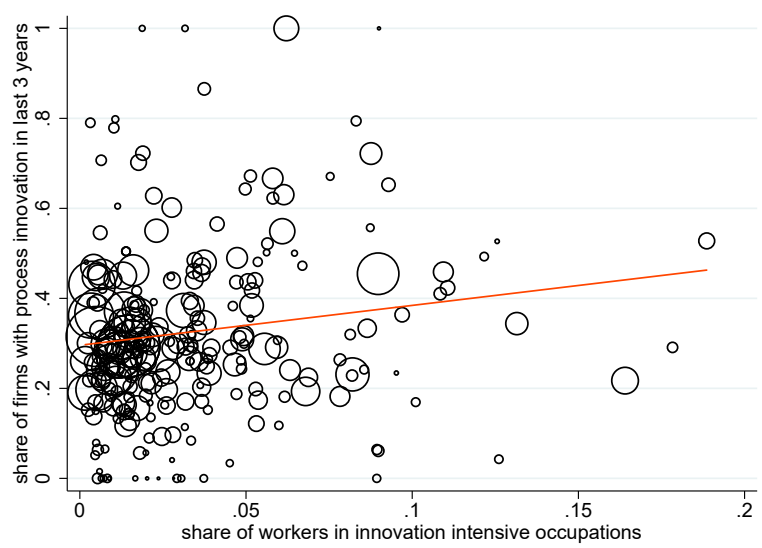

(f) Patents vs Product or Process innovation share

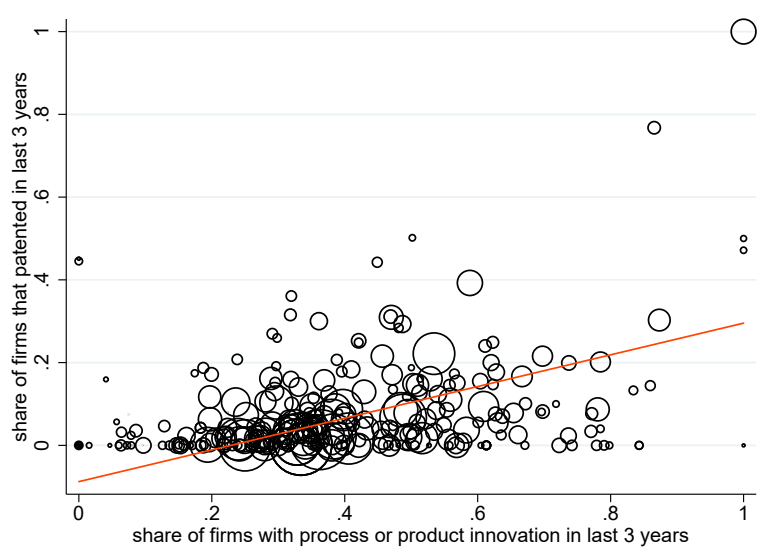

Notes: The share of workers in innovation intensive occupations in each sector is constructed using RAIS data for the year 2000 and the methodology described in Section 2.4. All measures of innovation at industry level (R\&D expenditure over sales, patent share, product and process innovation share) are computed using the 2000 Pesquisa de Inovação Tecnológica (PINTEC). Dot size captures size of the industry in terms of number of employees in 2000. 
Figure A.4: Geographical distribution of share of manufacturing workers in innovation intensive occupations in 2000

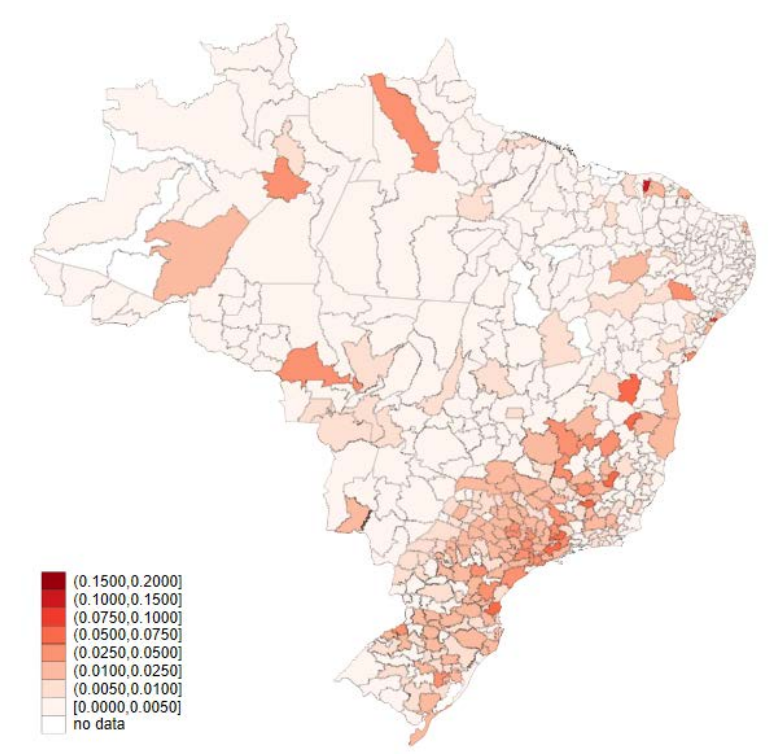

Notes: The Figure reports the share of innovation intensive workers over total workers in the manufacturing sector in the year 2000 by microregion. Innovation intensive occupations are defined using the methodology described in Section 2.4 . 
Figure A.5: Agricultural technical change and the reallocation of innovation workers across industries and occupations

(a) Reallocation of innovative workers from $H$ to $L$ Industry

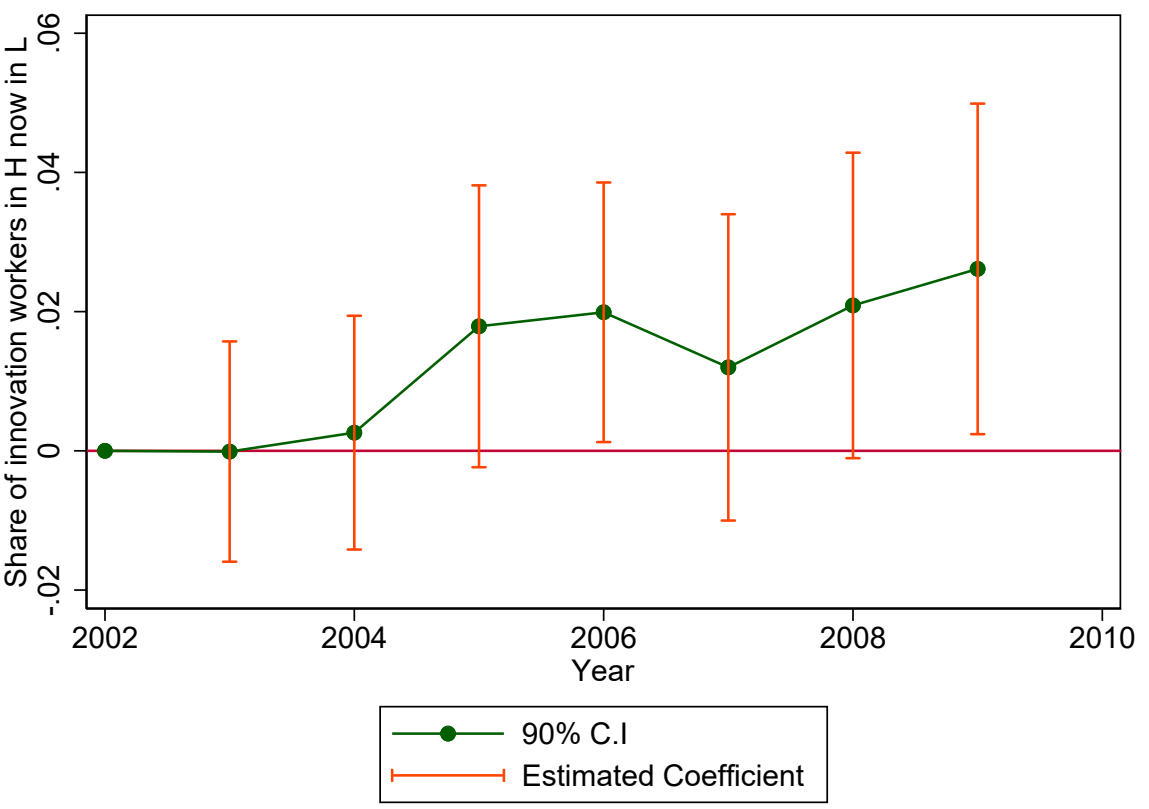

(b) Decomposition by new occupation in the $L$ industry

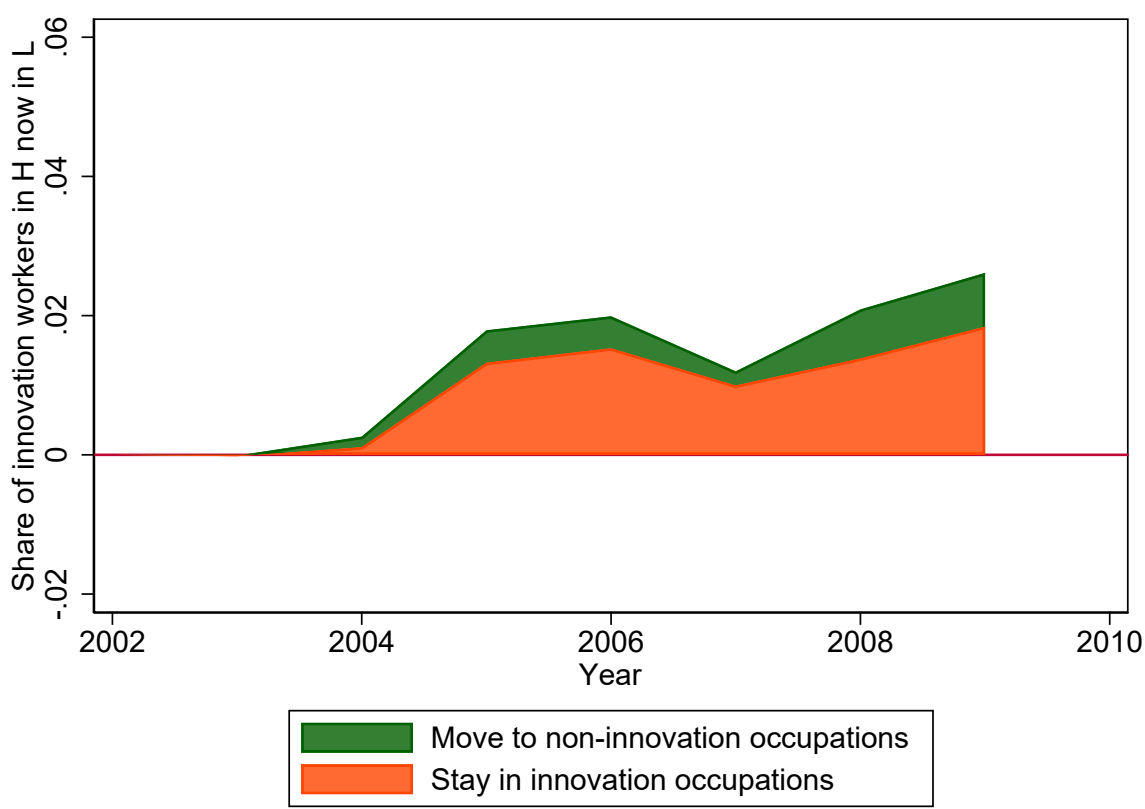

Notes: Graph (a) shows the point estimates and the $90 \%$ confidence intervals for the estimates of the $\beta_{j}$ coefficients of equation (2) where the outcome variable is the share of workers who were employed in innovative occupations in the $\mathrm{H}$ sector during a year between 1998 and 2002 that moved to the $\mathrm{L}$ industry in microregion $k$ located in region $r$ at the end of year $t$ (Source: RAIS). Graph (b) decomposes Graph (a) by the new occupation in the L industry of workers who were employed in innovative occupations in the H sector during a year between 1998 and 2002. An occupation is classified as innovative following the methodology outlined in Section 2.4. Manufacturing industries are classified as L or H depending on whether their R\&D intensity is below or above the median in 2000 (weighting industries by number of employees so that each group captures around 50 percent of total manufacturing employment). We define R\&D intensity as R\&D expenditure as a share of total sales at baseline and we source it from from the 2000 Pesquisa de Inovação Tecnológica (PINTEC). Standard errors are clustered at the microregion level. 
Table A.1: Effect of Agricultural Technical Change on GE Soy Adoption

\begin{tabular}{|c|c|c|c|c|}
\hline Panel A & $\begin{array}{c}\Delta \text { GE-soy area share } \\
(1)\end{array}$ & $\begin{array}{c}\Delta \text { GE-soy area share } \\
(2)\end{array}$ & $\begin{array}{c}\Delta \text { non-GE soy area share } \\
(3)\end{array}$ & $\begin{array}{c}\Delta \text { non-GE soy area share } \\
(4)\end{array}$ \\
\hline$\Delta A^{\text {soy }}$ & $\begin{array}{c}0.022^{* * *} * \\
{[0.005]}\end{array}$ & $\begin{array}{c}0.020^{* * *} \\
{[0.004]}\end{array}$ & $\begin{array}{c}-0.007^{*} \\
{[0.004]}\end{array}$ & $\begin{array}{c}-0.008^{* *} \\
{[0.004]}\end{array}$ \\
\hline Share rural population & $\begin{array}{c}0.034^{* * *} \\
{[0.010]}\end{array}$ & $\begin{array}{c}0.117^{* * *} \\
{[0.023]}\end{array}$ & $\begin{array}{l}-0.009 \\
{[0.009]}\end{array}$ & $\begin{array}{c}-0.057^{* *} \\
{[0.023]}\end{array}$ \\
\hline Log Income per capita & & $\begin{array}{l}-0.009 \\
{[0.006]}\end{array}$ & & $\begin{array}{l}-0.002 \\
{[0.007]}\end{array}$ \\
\hline Literacy rate & & $\begin{array}{c}0.162^{* * * *} \\
{[0.034]}\end{array}$ & & $\begin{array}{l}-0.043 \\
{[0.035]}\end{array}$ \\
\hline Log population density & & $\begin{array}{c}0.005^{* * *} \\
{[0.001]}\end{array}$ & & $\begin{array}{c}-0.006^{* * *} \\
{[0.001]}\end{array}$ \\
\hline Observations & 557 & 557 & 557 & 557 \\
\hline R-squared & 0.094 & 0.208 & 0.013 & 0.053 \\
\hline Panel B & $\begin{array}{l}\Delta \text { Soy area share } \\
(1)\end{array}$ & $\begin{array}{c}\Delta \text { Soy area share } \\
(2)\end{array}$ & $\begin{array}{c}\Delta \text { Maize area share } \\
(3)\end{array}$ & $\begin{array}{c}\Delta \text { Maize area share } \\
(4)\end{array}$ \\
\hline$\Delta A^{\text {soy }}$ & $\begin{array}{c}0.022^{* * * *} \\
{[0.004]}\end{array}$ & $\begin{array}{c}0.016^{* * *} \\
{[0.004]}\end{array}$ & $\begin{array}{l}-0.006 \\
{[0.004]}\end{array}$ & $\begin{array}{c}0.000 \\
{[0.004]}\end{array}$ \\
\hline$\Delta A^{\text {maize }}$ & $\begin{array}{c}-0.003^{* *} \\
{[0.001]}\end{array}$ & $\begin{array}{l}-0.001 \\
{[0.001]}\end{array}$ & $\begin{array}{c}0.005^{* * *} * \\
{[0.002]}\end{array}$ & $\begin{array}{l}0.003^{*} \\
{[0.002]}\end{array}$ \\
\hline Share rural population & $\begin{array}{c}0.029^{* * *} * \\
{[0.007]}\end{array}$ & $\begin{array}{c}0.064^{* * *} \\
{[0.013]}\end{array}$ & $\begin{array}{c}0.020^{* * * *} \\
{[0.008]}\end{array}$ & $\begin{array}{c}0.012 \\
{[0.015]}\end{array}$ \\
\hline Log Income per capita & & $\begin{array}{c}-0.010^{*} \\
{[0.006]}\end{array}$ & & $\begin{array}{l}-0.011 \\
{[0.007]}\end{array}$ \\
\hline Literacy rate & & $\begin{array}{c}0.122^{* * *} \\
{[0.018]}\end{array}$ & & $\begin{array}{l}-0.002 \\
{[0.023]}\end{array}$ \\
\hline Log population density & & $\begin{array}{l}-0.001 \\
{[0.001]}\end{array}$ & & $\begin{array}{c}0.003^{* * *} * \\
{[0.001]}\end{array}$ \\
\hline Observations & 557 & 557 & 556 & 556 \\
\hline R-squared & 0.135 & 0.245 & 0.041 & 0.066 \\
\hline
\end{tabular}

Notes: Changes in dependent variables are calculated over the years 1996 and 2006 (source: Agricultural Census). The unit of observation is the microregion. Robust standard errors reported in brackets. Significance levels: ${ }^{* * *} p<0.01,{ }^{* *} p<0.05,{ }^{*} p<0.1$. 
Table A.2: Classification of Manufacturing Industries by R\&D Intensity

\begin{tabular}{|c|c|c|c|}
\hline IBGE Code & Description & R\&D Share of Sales & Skill Intensity \\
\hline 26091 & Ceramic products & 0.106 & 0.275 \\
\hline 34001 & Manufacturing and assembly of motor vehicles & 0.105 & 0.738 \\
\hline 23030 & Production of nuclear fuels & 0.100 & 0.830 \\
\hline 31002 & Electrical material for vehicles & 0.088 & 0.599 \\
\hline 27001 & Steel products & 0.084 & 0.659 \\
\hline 35030 & Construction, assembly and repair of airplanes & 0.080 & 0.875 \\
\hline 28002 & Foundries, stamping shops, powder metallurgy and metal treatment services & 0.066 & 0.502 \\
\hline 33003 & Machines, equipment for electronic systems for industrial automation, and control & 0.064 & 0.848 \\
\hline 24020 & Pharmaceutical products & 0.062 & 0.809 \\
\hline 33001 & Medical equipment & 0.061 & 0.753 \\
\hline 29002 & Appliances & 0.058 & 0.709 \\
\hline 34002 & Cabins, car bodies, trailers and parts for motor vehicles & 0.058 & 0.637 \\
\hline 20000 & Wooden products & 0.055 & 0.247 \\
\hline 33004 & Equipment, instruments and optical, photographic and cinematographic material & 0.055 & 0.709 \\
\hline 33002 & Measuring, testing and control equipment - except for controlling industrial processes & 0.054 & 0.725 \\
\hline 24010 & Paints, dyes, varnish, enamels and lacquers & 0.053 & 0.656 \\
\hline 25020 & Plastic products & 0.052 & 0.543 \\
\hline 32000 & Electronic material and communications equipment & 0.052 & 0.757 \\
\hline 31001 & Machines, equipment and miscellaneous electric material - except for vehicles & 0.051 & 0.678 \\
\hline 27003 & Foundries & 0.051 & 0.462 \\
\hline 15043 & Other food products & 0.049 & 0.426 \\
\hline 36090 & Miscellaneous products & 0.048 & 0.576 \\
\hline 23010 & Coke plants & 0.047 & 0.487 \\
\hline 37000 & Recycling & 0.045 & 0.304 \\
\hline 35090 & Miscellaneous transportation equipment & 0.044 & 0.581 \\
\hline 21002 & Corrugated cardboard, packaging, and paper and cardboard objects & 0.044 & 0.577 \\
\hline 17001 & Processing of fibers, weaving and cloth making & 0.043 & 0.471 \\
\hline 28001 & Metal products - except machines and equipment & 0.042 & 0.496 \\
\hline 24030 & Soap, detergents, cleaning products and toiletries & 0.042 & 0.658 \\
\hline 29001 & Machines and equipment - except appliances & 0.041 & 0.605 \\
\hline 21001 & Pulp, paper and smooth cardboard, poster paper and card paper & 0.040 & 0.602 \\
\hline 34003 & Reconditioning or restoration of engines of motor vehicles & 0.038 & 0.556 \\
\hline 24090 & Miscellaneous chemical products & 0.037 & 0.635 \\
\hline 25010 & Rubber products & 0.036 & 0.567 \\
\hline 26092 & Miscellaneous products of non-metallic minerals & 0.035 & 0.382 \\
\hline 22000 & Editing, printing and reproduction of recordings & 0.035 & 0.702 \\
\hline 19012 & Leather objects & 0.034 & 0.453 \\
\hline 30000 & Office machines and data-processing equipment & 0.034 & 0.852 \\
\hline 36010 & Pieces of furniture & 0.034 & 0.402 \\
\hline 26010 & Glass and glass products & 0.031 & 0.576 \\
\hline 15021 & Preserves of fruit, vegetables and other vegetable products & 0.029 & 0.484 \\
\hline 17002 & Manufacturing of textile objects based on cloth - except for garments & 0.028 & 0.433 \\
\hline 18001 & Making of clothing articles and accessories - except on order & 0.023 & 0.425 \\
\hline 18002 & Making clothing articles and accessories - on order & 0.023 & 0.435 \\
\hline 18999 & Making of clothing articles and accessories - on order or not & 0.023 & 0.690 \\
\hline 27002 & Non-ferrous metals & 0.022 & 0.644 \\
\hline 15030 & Dairy products & 0.022 & 0.433 \\
\hline 19020 & Footwear & 0.019 & 0.348 \\
\hline 15010 & Slaughtering and preparation of meat and fish & 0.018 & 0.355 \\
\hline 35010 & Construction and repair of boats & 0.018 & 0.493 \\
\hline 23020 & Products in oil refining & 0.015 & 0.763 \\
\hline 33005 & Chronometers, clocks and watches & 0.015 & 0.751 \\
\hline 23400 & Alcohol production & 0.014 & 0.350 \\
\hline 15041 & Manufacturing and refining of sugar & 0.013 & 0.334 \\
\hline 15042 & Roasting and grinding of coffee & 0.013 & 0.499 \\
\hline 19011 & Tanning and other preparations of leather & 0.013 & 0.325 \\
\hline 16000 & Tobacco products & 0.013 & 0.496 \\
\hline 15050 & Beverages & 0.012 & 0.555 \\
\hline 15022 & Vegetable fat and oil & 0.009 & 0.446 \\
\hline 35020 & Construction and assembly of locomotives, cars and other rolling stock & 0.004 & 0.632 \\
\hline \multicolumn{2}{|r|}{ Median } & 0.041 & 0.432 \\
\hline
\end{tabular}

Notes: The industry codes correspond to the CNAE-Domiciliar, the industry classification used in the 2000 Population Census. Industries are sorted by their R\&D intensity at baseline. We measure R\&D intensity as R\&D expenditure as a share of total sales at baseline and we source it from from the 2000 Pesquisa de Inovação Tecnológica (PINTEC). We define skill intensity as the share of skilled individuals in a particular industry in Brazil at baseline and we source it from the 2000 Population Census. The correlation between these variables is approximately 0.34 . Industries below the median are classified as low and the ones above the median as high. 
Table A.3: Keywords Used to Identify Innovative Occupations

Panel A: Nouns or combination of nouns from task description of occupations

\begin{tabular}{ll} 
Portuguese & English \\
${$\cline { 1 - 2 }$} }$ & research and development \\
inovação & innovation \\
p\&d & R\&D \\
desenvolvimento de produtos & product development \\
desenvolvimento de processos & process development \\
pesquisador & researcher \\
novas tecnologias & new technologies \\
protótipos & prototypes \\
pesquisas tecnologicas & technological research \\
automaçao de processos & process automation \\
& \\
Panel B: Actions (verb + noun) from task description of occupations \\
\hline
\end{tabular}

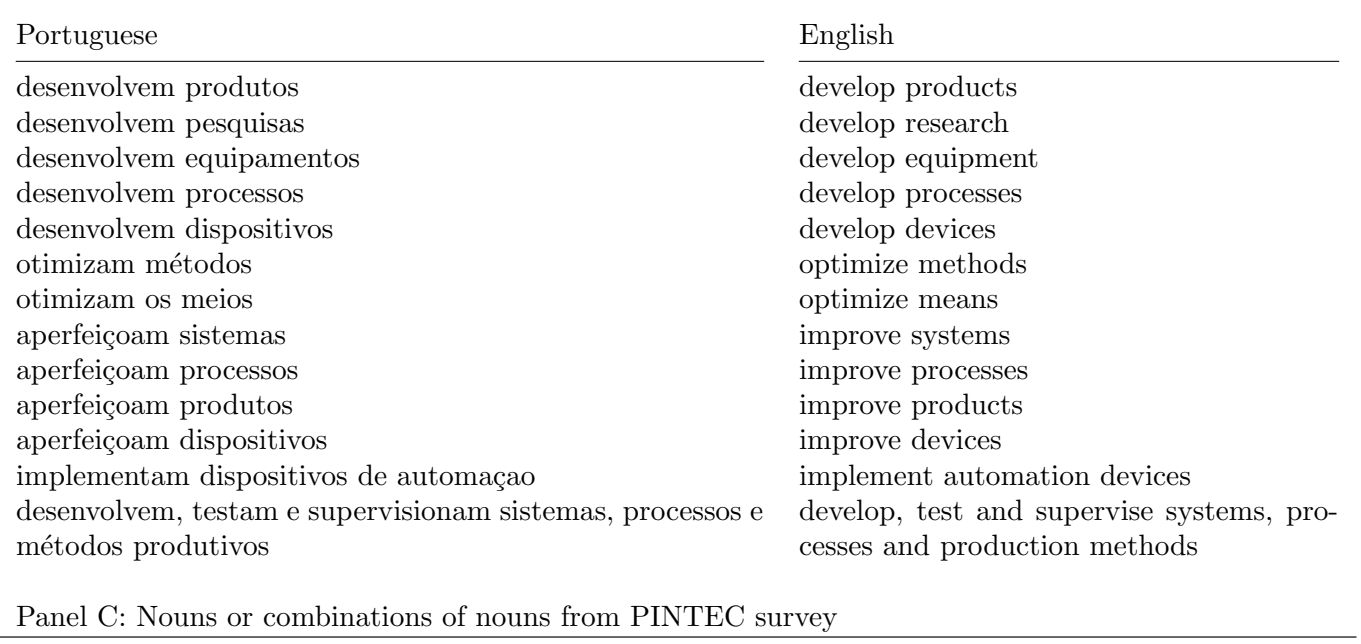

\begin{tabular}{ll} 
Portuguese & English \\
${$\cline { 1 - 2 }$}$ new product $}$ \\
produtos novos / novos produtos & new products \\
produto aprimorado & improved product \\
produtos aprimorados & improved produts \\
inovação de produto & product innovation \\
aperfeiçoamento de produto & product improvement \\
processo novo / novo processo & new process \\
processos novos / novos processos & new processes \\
processo aprimorado & improved process \\
processos aprimorados & improved processes \\
inovação de processo & process innovation \\
aperfeiçoamento de processo & process improvement \\
\hline
\end{tabular}

Notes: The Table reports the keywords used to identify innovation intensive occupations and their English translation. Keywords reported in Panels A and B are sourced from the "Brazilian Classification of Occupations", Ministry of Labor, 3rd Edition (2010). Keywords reported in Panel C are sourced from the Technical Appendix of the 2008 PINTEC Survey. 
Table A.4: Industry-level Measures of Innovation

\begin{tabular}{|c|c|c|c|c|c|}
\hline \multirow{2}{*}{$\begin{array}{l}\text { Outcome: } \\
\text { Measure: }\end{array}$} & \multicolumn{5}{|c|}{ Measure of Industrial Innovation } \\
\hline & $\begin{array}{c}\log \mathrm{R} \& \mathrm{D} \text { expenditure } \\
\text { over sales } \\
(1)\end{array}$ & $\begin{array}{c}\text { Share of } \\
\text { patenting firms } \\
(2)\end{array}$ & $\begin{array}{l}\text { Share of product } \\
\text { innovation firms } \\
(3)\end{array}$ & $\begin{array}{l}\text { Share of process } \\
\text { innovation firms } \\
\qquad(4)\end{array}$ & $\begin{array}{l}\text { Share of product or process } \\
\text { innovation firms } \\
(5)\end{array}$ \\
\hline Share of innovation & $\begin{array}{c}5.929 * * \\
(2.502)\end{array}$ & $\begin{array}{c}1.557^{* * *} \\
(0.411)\end{array}$ & $\begin{array}{c}2.178^{* * *} \\
(0.406)\end{array}$ & $\begin{array}{c}0.885^{* *} \\
(0.427)\end{array}$ & $\begin{array}{c}1.628^{* * *} \\
(0.473)\end{array}$ \\
\hline Observations & 271 & 274 & 274 & 274 & 274 \\
\hline R-squared & 0.062 & 0.166 & 0.172 & 0.037 & 0.098 \\
\hline
\end{tabular}

Notes: Dependent variables are calculated from 2000 Pesquisa de Inovação Tecnológica (PINTEC). The unit of observation is the 4-digit CNAE industry. These regressions compute the OLS coefficient of a number of outcomes on the share of innovation workers. The share of innovation workers in each industry are computed for the year 2000 using the methodology described in Section 2.4. All regressions are weighted by number of workers in each industry in 2000. Robust standard errors reported in brackets. Significance levels: 
Table A.5: Internal migration

\begin{tabular}{|c|c|c|c|c|c|c|c|c|c|c|}
\hline \multirow{2}{*}{$\begin{array}{l}\text { Skill Group: } \\
\text { Outcomes }\end{array}$} & \multicolumn{4}{|c|}{ All } & \multicolumn{3}{|c|}{ Skilled } & \multicolumn{3}{|c|}{ Unskilled } \\
\hline & $\Delta \log L$ & Net Migration & In-Migration & Out-Migration & Net Migration & In-Migration & Out-Migration & Net Migration & In-Migration & Out-Migration \\
\hline & $(1)$ & $(2)$ & (3) & $(4)$ & $(5)$ & (6) & $(7)$ & $(8)$ & (9) & $(10)$ \\
\hline$\Delta A_{\text {soy }}$ & $\begin{array}{c}-0.014 \\
{[0.013]}\end{array}$ & $\begin{array}{c}0.004 \\
{[0.009]}\end{array}$ & $\begin{array}{c}0.002 \\
{[0.005]}\end{array}$ & $\begin{array}{l}-0.003 \\
{[0.006]}\end{array}$ & $\begin{array}{l}-0.001 \\
{[0.010]}\end{array}$ & $\begin{array}{l}-0.004 \\
{[0.005]}\end{array}$ & $\begin{array}{l}-0.003 \\
{[0.007]}\end{array}$ & $\begin{array}{c}0.012 \\
{[0.008]}\end{array}$ & $\begin{array}{c}0.011^{* *} \\
{[0.005]}\end{array}$ & $\begin{array}{l}-0.002 \\
{[0.006]}\end{array}$ \\
\hline Observations & 557 & 557 & 557 & 557 & 557 & 557 & 557 & 557 & 557 & 557 \\
\hline R-squared & 0.171 & 0.553 & 0.401 & 0.592 & 0.507 & 0.380 & 0.593 & 0.582 & 0.407 & 0.566 \\
\hline Controls & Yes & Yes & Yes & Yes & Yes & Yes & Yes & Yes & Yes & Yes \\
\hline
\end{tabular}




\section{Table A.6: Effect of technical change in soy on wages by skill group}

\section{Panel A}

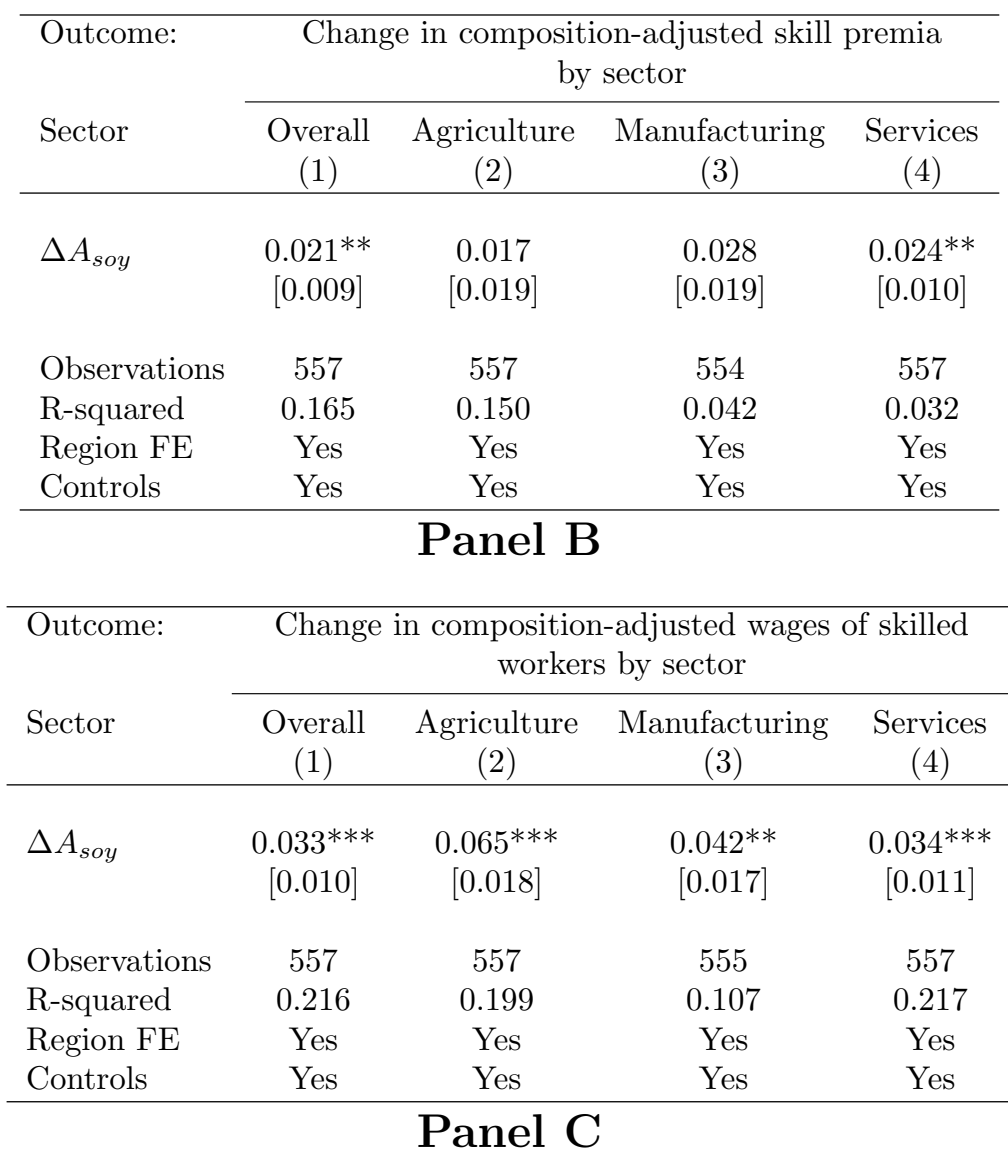

\begin{tabular}{lcccc}
\hline Outcome: & \multicolumn{3}{c}{$\begin{array}{c}\text { Change in composition-adjusted wages of unskilled } \\
\text { workers by sector }\end{array}$} \\
\cline { 2 - 5 } Sector & $\begin{array}{c}\text { Overall } \\
(1)\end{array}$ & $\begin{array}{c}\text { Agriculture } \\
(2)\end{array}$ & $\begin{array}{c}\text { Manufacturing } \\
(3)\end{array}$ & $\begin{array}{c}\text { Services } \\
(4)\end{array}$ \\
\hline \multirow{3}{*}{$\Delta A_{\text {soy }}$} & 0.012 & $0.045^{* * *}$ & 0.012 & 0.010 \\
& {$[0.008]$} & {$[0.012]$} & {$[0.012]$} & {$[0.009]$} \\
Observations & 557 & 557 & 556 & 557 \\
R-squared & 0.387 & 0.170 & 0.104 & 0.293 \\
Region FE & Yes & Yes & Yes & Yes \\
Controls & Yes & Yes & Yes & Yes \\
\hline
\end{tabular}

Notes: Changes in wages and skill premia are calculated over the years 2000 to 2010. Controls include the share of rural population, income per capita (in logs), population density (in logs), literacy rate, all observed in 1991, and a measure of technical change in maize. Dependent variables are computed from a Mincerian regression of log of hourly wages on microregion fixed effects, and a vector of individual characteristics that includes dummies for sector, skill group, age group, race, and all the interactions between these variables. Robust standard errors reported in brackets. Significance levels: ${ }^{* * *} p<0.01,{ }^{* *} p<0.05,{ }^{*} p<0.1$. 


\section{Table A.7: Effect of technical change in soy on the number of workers at the minimum wage}

\begin{tabular}{lccc}
\hline Outcome: & \multicolumn{3}{c}{$\begin{array}{c}\text { Change in the share of workers } \\
\text { at the minimum wage by sector }\end{array}$} \\
\cline { 2 - 4 } Industry & $\begin{array}{c}\text { All Manufacturing } \\
(1)\end{array}$ & $\begin{array}{c}\text { L Industry } \\
(2)\end{array}$ & $\begin{array}{c}\text { H Industry } \\
(3)\end{array}$ \\
\hline \multirow{2}{*}{$\Delta A_{\text {soy }}$} & $0.177^{* * *}$ & $0.207^{* * *}$ & $0.185^{* * *}$ \\
& {$[0.044]$} & {$[0.048]$} & {$[0.045]$} \\
Observations & 556 & & \\
R-squared & 0.184 & 555 & 555 \\
Region FE & Yes & 0.221 & 0.302 \\
Controls & Yes & Yes & Yes \\
\hline
\end{tabular}

Notes: Changes in dependent variables are calculated over the years 2000 and 2010 (source: Population Censuses). The unit of observation is the microregion. Workers at the minimum wage are workers paid below the mandatory minimum wage in 2000 and 2010. Controls include the share of rural population, income per capita (in logs), population density (in logs), literacy rate, all observed in 1991, and a measure of technical change in maize. Robust standard errors reported in brackets. Significance levels: ${ }^{* * *} p<0.01,{ }^{* *} p<0.05,{ }^{*} p<0.1$. 
Table A.8: Ratio high- to low-skilled workers

\begin{tabular}{|c|c|c|c|c|}
\hline \multirow{2}{*}{$\begin{array}{l}\text { Outcome: } \\
\text { Sector/Industry }\end{array}$} & \multicolumn{2}{|c|}{$\begin{array}{c}\text { Log Ratio of high- to low-skilled } \\
\text { workers by sector }\end{array}$} & \multicolumn{2}{|c|}{$\begin{array}{l}\text { Log Ratio of high- to low-skilled } \\
\text { workers by manufacturing industry }\end{array}$} \\
\hline & $\begin{array}{c}\text { Agriculture } \\
\text { (1) }\end{array}$ & $\begin{array}{l}\text { Manufacturing } \\
(2)\end{array}$ & $\begin{array}{l}\text { L Industry } \\
(3)\end{array}$ & $\begin{array}{l}\text { H Industry } \\
(4)\end{array}$ \\
\hline$\Delta A_{\text {soy }}$ & $\begin{array}{c}0.160^{* * *} \\
{[0.044]}\end{array}$ & $\begin{array}{c}0.038 \\
{[0.041]}\end{array}$ & $\begin{array}{l}-0.041 \\
{[0.038]}\end{array}$ & $\begin{array}{c}0.000 \\
{[0.043]}\end{array}$ \\
\hline Observations & 557 & 556 & 556 & 546 \\
\hline R-squared & 0.256 & 0.144 & 0.072 & 0.018 \\
\hline Region FE & Yes & Yes & Yes & Yes \\
\hline Controls & Yes & Yes & Yes & Yes \\
\hline
\end{tabular}

Notes: Changes in dependent variables are calculated over the years 2000 and 2010 (source: Population Censuses). The unit of observation is the microregion. All the regressions include as controls the share of rural population, income per capita (in logs), population density (in logs), literacy rate, all observed in the 1991 Population Census, a measure of technical change in maize and region fixed effects. Robust standard errors reported in brackets. Significance levels: ${ }^{* * *} p<0.01,{ }^{* *} p<0.05,{ }^{*} p<0.1$. 
Table A.9: Labor (direct) and Capital (indirect) Channels of Structural Transformation

\begin{tabular}{|c|c|c|c|c|c|}
\hline \multirow{3}{*}{$\begin{array}{l}\text { Outcome: } \\
\text { Region/Industry: }\end{array}$} & \multicolumn{5}{|c|}{ Change in manufacturing employment share } \\
\hline & All & Soy regions & Non-soy regions & $L$ industries & $H$ industries \\
\hline & $(1)$ & $(2)$ & $(3)$ & $(4)$ & $(5)$ \\
\hline \multirow{2}{*}{$\Delta A_{\text {soy }}$} & $0.015^{* * *}$ & $0.020^{* * *}$ & -0.002 & $0.014^{* * *}$ & 0.001 \\
\hline & {$[0.004]$} & {$[0.005]$} & {$[0.006]$} & {$[0.003]$} & {$[0.003]$} \\
\hline \multirow[t]{2}{*}{$\Delta$ Exposure to capital inflows } & $0.023^{*}$ & 0.001 & 0.042 & 0.004 & $0.019^{*}$ \\
\hline & {$[0.014]$} & {$[0.016]$} & {$[0.028]$} & {$[0.010]$} & {$[0.011]$} \\
\hline Observations & 540 & 385 & 155 & 540 & 540 \\
\hline R-squared & 0.253 & 0.099 & 0.431 & 0.292 & 0.076 \\
\hline
\end{tabular}

Notes: Changes in dependent variables are calculated over the years 2000 and 2010 (source: Population Censuses). The unit of observation is the microregion. All the regressions include as controls the share of rural population, income per capita (in logs), population density (in logs), literacy rate, all observed in the 1991 Population Census, a measure of technical change in maize and region fixed effects. Observations are weighted by total employment in a given microregion in 2000. Robust standard errors reported in brackets. Significance levels: ${ }^{* * *} p<0.01,{ }^{* *} p<0.05,{ }^{*} p<0.1$. 


\section{Table A.10: Effect of agricultural technical change on manufacturing outcomes excluding industries linked to soy Yearly Social Security Data (1998-2009) and Yearly Manufacturing Survey Data (2000-2009)}

Panel A

\begin{tabular}{lcccc}
\hline \multirow{2}{*}{ Outcome: } & \multicolumn{3}{c}{$\begin{array}{c}\text { Employment by manufacturing } \\
\text { industry }\end{array}$} & $\begin{array}{c}\text { Capital by manufacturing } \\
\text { industry }\end{array}$ \\
\cline { 2 - 5 } Industry: & $\begin{array}{c}\text { L Industry } \\
(1)\end{array}$ & $\begin{array}{c}\text { H Industry } \\
(2)\end{array}$ & $\begin{array}{c}\text { L Industry } \\
(3)\end{array}$ & $\begin{array}{c}\text { H Industry } \\
(4)\end{array}$ \\
\hline & $0.124^{* *}$ & -0.006 & $0.363^{* * *}$ & 0.043 \\
$A_{\text {soy }}$ & {$[0.050]$} & {$[0.041]$} & {$[0.118]$} & {$[0.122]$} \\
& & & & \\
Observations & 5,640 & 5,640 & 3,001 & 2,942 \\
R-squared & 0.448 & 0.385 & 0.900 & 0.894 \\
Region x Year FEs & Yes & Yes & Yes & Yes \\
Controls & Yes & Yes & Yes & Yes \\
\hline
\end{tabular}

Panel B

\begin{tabular}{|c|c|c|c|c|c|c|}
\hline \multirow{2}{*}{$\begin{array}{l}\text { Outcomes: } \\
\text { Measure: }\end{array}$} & \multicolumn{3}{|c|}{ L Industry Productivity } & \multicolumn{3}{|c|}{ H Industry Productivity } \\
\hline & $\begin{array}{c}\text { Log Value Added } \\
\text { per Worker } \\
(1)\end{array}$ & $\begin{array}{c}\text { Log Value Added } \\
\text { per Wage Bill } \\
(2)\end{array}$ & $\begin{array}{c}\text { Log TFP } \\
(3) \\
\end{array}$ & $\begin{array}{c}\text { Log Value Added } \\
\text { per Worker } \\
(4)\end{array}$ & $\begin{array}{c}\text { Log Value Added } \\
\text { per Wage Bill } \\
(5)\end{array}$ & $\begin{array}{c}\text { Log TFP } \\
(6)\end{array}$ \\
\hline$A_{\text {soy }}$ & $\begin{array}{c}-0.150^{* *} \\
{[0.061]}\end{array}$ & $\begin{array}{c}-0.135 * * \\
{[0.054]}\end{array}$ & $\begin{array}{c}-0.277^{* * *} \\
{[0.096]}\end{array}$ & $\begin{array}{c}-0.126^{*} \\
{[0.072]}\end{array}$ & $\begin{array}{c}-0.118^{* *} \\
{[0.057]}\end{array}$ & $\begin{array}{c}-0.166^{*} \\
{[0.088]}\end{array}$ \\
\hline Observations & 3,055 & 3,055 & 2,999 & 3,069 & 3,069 & 2,922 \\
\hline R-squared & 0.770 & 0.568 & 0.611 & 0.797 & 0.633 & 0.588 \\
\hline Region x Year FEs & Yes & Yes & Yes & Yes & Yes & Yes \\
\hline Controls & Yes & Yes & Yes & Yes & Yes & Yes \\
\hline
\end{tabular}

Panel C

\begin{tabular}{lcccc} 
Outcomes: & \multicolumn{2}{c}{ Wage Bill of Non-Innovation Workers } & \multicolumn{2}{c}{ Wage Bill of Innovation Workers } \\
\cline { 2 - 5 } Industry: & $\begin{array}{c}\text { L Industry } \\
(1)\end{array}$ & $\begin{array}{c}\text { H Industry } \\
(2)\end{array}$ & $\begin{array}{c}\text { L Industry } \\
(3)\end{array}$ & $\begin{array}{c}\text { H Industry } \\
(4)\end{array}$ \\
\hline \multirow{2}{*}{$A_{\text {soy }}$} & $0.153^{* * *}$ & -0.005 & 0.034 & $-0.284^{*}$ \\
& {$[0.047]$} & {$[0.049]$} & {$[0.111]$} & {$[0.167]$} \\
Observations & 3,816 & 3,816 & 3,796 & 3,815 \\
R-squared & 0.983 & 0.987 & 0.935 & 0.927 \\
Controls & Yes & Yes & Yes & Yes \\
\hline
\end{tabular}

Notes: This table replicates the results presented in Table 5 (Panel A), Table 6 (Panel B) and Table 7 (Panel C) excluding sectors directly linked to soy via input-output linkages. Such sectors include: "Slaughtering and preparation of meat and fish" (SNA code 1091), "Other food products" (SNA code 1093), "Fertilizers and other inorganic chemicals" $(2412,2413,2419)$ and "Refined petroleum" (232). Standard errors clustered at the microregion level reported in parentheses. Significance levels: ${ }^{* * *} p<0.01,{ }^{* *} p<0.05,{ }^{*} p<0.1$. 
Table A.11: Geographical spillovers of the effect of technical change in soy on manufacturing outcomes

\begin{tabular}{|c|c|c|c|c|c|c|c|c|c|}
\hline \multirow[t]{2}{*}{ Outcomes: } & \multicolumn{3}{|c|}{ Log Value Added per Worker } & \multicolumn{3}{|c|}{ Log Value Added per Wage Bill } & \multicolumn{3}{|c|}{ Log TFP } \\
\hline & $(1)$ & $(2)$ & (3) & (4) & $(5)$ & $(6)$ & $(7)$ & (8) & $(9)$ \\
\hline$A_{\text {soy }}$ & $\begin{array}{c}-0.141^{* * *} \\
{[0.043}\end{array}$ & $\begin{array}{c}-0.120^{*} \\
{[0.067]}\end{array}$ & $\begin{array}{c}-0.120^{*} \\
{[0.068]}\end{array}$ & $\begin{array}{c}-0.133^{* * *} \\
{[0.040]}\end{array}$ & $\begin{array}{c}-0.107^{*} \\
{[0.061]}\end{array}$ & $\begin{array}{c}-0.108^{*} \\
{[0.062]}\end{array}$ & $\begin{array}{c}-0.197^{* *} \\
{[0.080]}\end{array}$ & $\begin{array}{c}-0.207^{*} \\
{[0.117]}\end{array}$ & $\begin{array}{c}-0.205^{*} \\
{[0.118]}\end{array}$ \\
\hline$A_{\text {soy }} \mathrm{N} 5$ & & $\begin{array}{l}-0.028 \\
{[0.061]}\end{array}$ & $\begin{array}{l}-0.023 \\
{[0.092]}\end{array}$ & & $\begin{array}{l}-0.034 \\
{[0.056]}\end{array}$ & $\begin{array}{l}-0.017 \\
{[0.079]}\end{array}$ & & $\begin{array}{c}0.011 \\
{[0.112]}\end{array}$ & $\begin{array}{l}-0.016 \\
{[0.131]}\end{array}$ \\
\hline$A_{\text {soy }} \mathrm{N} 5-\mathrm{N} 10$ & & & $\begin{array}{l}-0.006 \\
{[0.071]}\end{array}$ & & & $\begin{array}{l}-0.021 \\
{[0.062]}\end{array}$ & & & $\begin{array}{c}0.037 \\
{[0.119]}\end{array}$ \\
\hline Observations & 3,070 & 3,070 & 3,070 & 3,070 & 3,070 & 3,070 & 3,069 & 3,069 & 3,069 \\
\hline R-squared & 0.876 & 0.876 & 0.876 & 0.735 & 0.735 & 0.735 & 0.544 & 0.544 & 0.544 \\
\hline Region x Year FEs & Yes & Yes & Yes & Yes & Yes & Yes & Yes & Yes & Yes \\
\hline Controls & Yes & Yes & Yes & Yes & Yes & Yes & Yes & Yes & Yes \\
\hline
\end{tabular}

Notes: The dependent variables correspond to the total value added divided by employment (in logs), and total factor productivity for each type of manufacturing industry in each microregion as a proxy for productivity. We use aggregate information from PIA at the microregion level for the time period 2000-2009. We include only those microregions that have positive employment for all the years in the sample. $A_{\text {soy }}$ is defined as potential soy yield under high inputs for the years between 2003 and 2009, and the potential soy yield under low inputs for the years between 2000 and 2002. $A_{\text {soy }}$ N5, $A_{\text {soy }}$ N5-N10 and $A_{\text {soy }}$ N10-20 are defined as the average potential soy yield for the five closest neighbors, the fifth to the tenth closest neighbors and the tenth to twentieth closest neighbors of a particular microregion weighted by the inverse distance. Controls include the share of rural population, income per capita (in logs), population density (in logs), literacy rate, all observed in 1991, all interacted with a linear trend, a measure of technical change in maize and region year fixed effects. Standard errors clustered at the microregion level reported in parentheses. Significance levels: ${ }^{* * *} p<0.01,{ }^{* *} p<0.05,{ }^{*} p<0.1$. 


\section{B Appendix: data}

\section{B.1 Total Factor Productivity}

In this Appendix, we describe how we compute the measure of total factor productivity at the microregion-industry level that we use in the empirical analysis. Concretely, we compute total factor productivity as the Solow residual of a Neoclassical Cobb-Douglas production function that combines skilled labor, unskilled labor, and capital and features constant returns to scale, i.e we start by assuming the following Cobb-Douglas value-added function for each industry $j$ in a microregion $i$ in a period $t$,

$$
V A_{i j t}=e^{z_{i j t}} S_{i j t}^{\alpha_{s, j}} U_{i j t}^{\alpha_{u, j}} K_{i j t}^{1-\alpha_{s, j}-\alpha_{u, j}}
$$

where $i$ indexes microregions, $j$ indexes industries and $t$ refers to time. Notice that for a given industry the production technology is the same across microregions and periods. As is well known in the Growth Accounting literature, the growth rate in value added can be decomposed into components associated to factor accumulation and technological progress. Moreover, assuming industries are perfectly competitive and price takers in factor markets, one can recover the parameters of the production function using data on factor shares.

More precisely, we calibrate the factor shares for skilled and unskilled labor by computing, for each type of labor, the aggregate wage bill divided by total value added in Brazil in 2000, 2001, and 2002 and then taking the average across years. Due to data limitations, in order to compute the value-added shares for each type of labor as $\alpha_{s, j}=\frac{W_{s, j} S_{j}}{V A_{j}}$ and $\alpha_{u, j}=\frac{W_{u, j} U_{j}}{V A_{j}}$ we need to take a two-step approach. First, we compute the labor share using data from PIA by aggregating the wage bill and value added at the national-industry level. Since PIA does not differentiate between skilled and unskilled labor, in a second stage we compute wage bill shares by type of labor in RAIS and, then, apportion the labor share previously computed in PIA to skilled and unskilled labor. Therefore, in practice $\alpha_{s, j}=\frac{W_{s, j}^{R A I S} S_{j}^{R A I S}}{W_{s, j}^{R A I S} S_{j}^{R A I S}+W_{u, j}^{R A I S} U_{j}^{R A I S}} \frac{W_{j}^{P I A} L_{j}^{P I A}}{V A_{j}^{P I A}}$ and $\alpha_{u, j}=\frac{W_{u, j}^{R A S} U_{j}^{R A I S}}{W_{s, j}^{R A S} S_{j}^{R A I S}+W_{u, j}^{R A I S} U_{j}^{R A I S}} \frac{W_{j}^{P I A} L_{j}^{P I A}}{V A_{j}^{P I A}}$. Then, we leverage the constant returns to scale assumption to compute the capital share $\alpha_{k, j}$ as $1-\alpha_{s, j}-\alpha_{u, j}$. In Table B.12, we describe the factor shares for the manufacturing $\mathrm{L}$ industry and the $\mathrm{H}$ industry.

Once we have computed the shares for the three types of factors, we compute $\log T F P$ in microregion $i$, industry $j$ and time $t$ as

$$
\log T F P_{i j t}=\log V A_{i j t}-\alpha_{k j} \log \left(p_{t} K_{i j t}\right)-\alpha_{1 j} \log \left(L_{1, i j t}\right)-\alpha_{2 j} \log \left(L_{2, i j t}\right)
$$




\section{Table B.12: Factor Shares}

\begin{tabular}{ccccccc}
\hline \multicolumn{3}{c}{ L Industry } & \multicolumn{3}{c}{ H Industry } \\
$\alpha_{s}$ & $\alpha_{u}$ & $\alpha_{k}$ & $\alpha_{s}$ & $\alpha_{u}$ & $\alpha_{k}$ \\
\hline 0.129 & 0.055 & 0.816 & 0.177 & 0.052 & 0.771 \\
\hline
\end{tabular}

\section{B.2 Wages}

To compute composition-adjusted wages we estimate the following Mincerian regressions:

$$
\ln \left(w_{i k t}\right)=\gamma_{k t}+H_{i k t} \beta_{H t}+\varepsilon_{i k t} \text { for } t=2000,2010
$$

where $\ln \left(w_{i j k t}\right)$ is the $\log$ hourly wage of individual $i$, working in sector $j$ in microregion $k$ at time $t$, and $\gamma_{k t}$ is a microregion fixed effect, while $H_{i j k t}$ is a vector of individual characteristics, which includes dummies for sector, skill group, age group, race, and all the interactions between these variables. We estimate the previous Mincerian regression for each microregion and for each broad sector separately. Also, we estimate these regressions constraining the sample to either unskilled or skilled labor only, recovering the unit price of labor in each microregion for each type of labor in both cross sections. Since the existing literature documented how Brazil has experienced a considerable reduction in its gender pay gap (Ferreira, Firpo, and Messina 2017), we estimate equation (6) only for male workers. Observations are weighted by their corresponding population census weight. Next, we use the microregion fixed effects estimated above as the unit price of labor for a given skill group in a given microregion, and we compute the change in unit prices of labor in microregion $k$ between 2000 and 2010 as $\Delta \gamma_{k}=\gamma_{k, 2010}-\gamma_{k, 2000}$, which gives us the change in the composition-adjusted wages at the microregion level. 